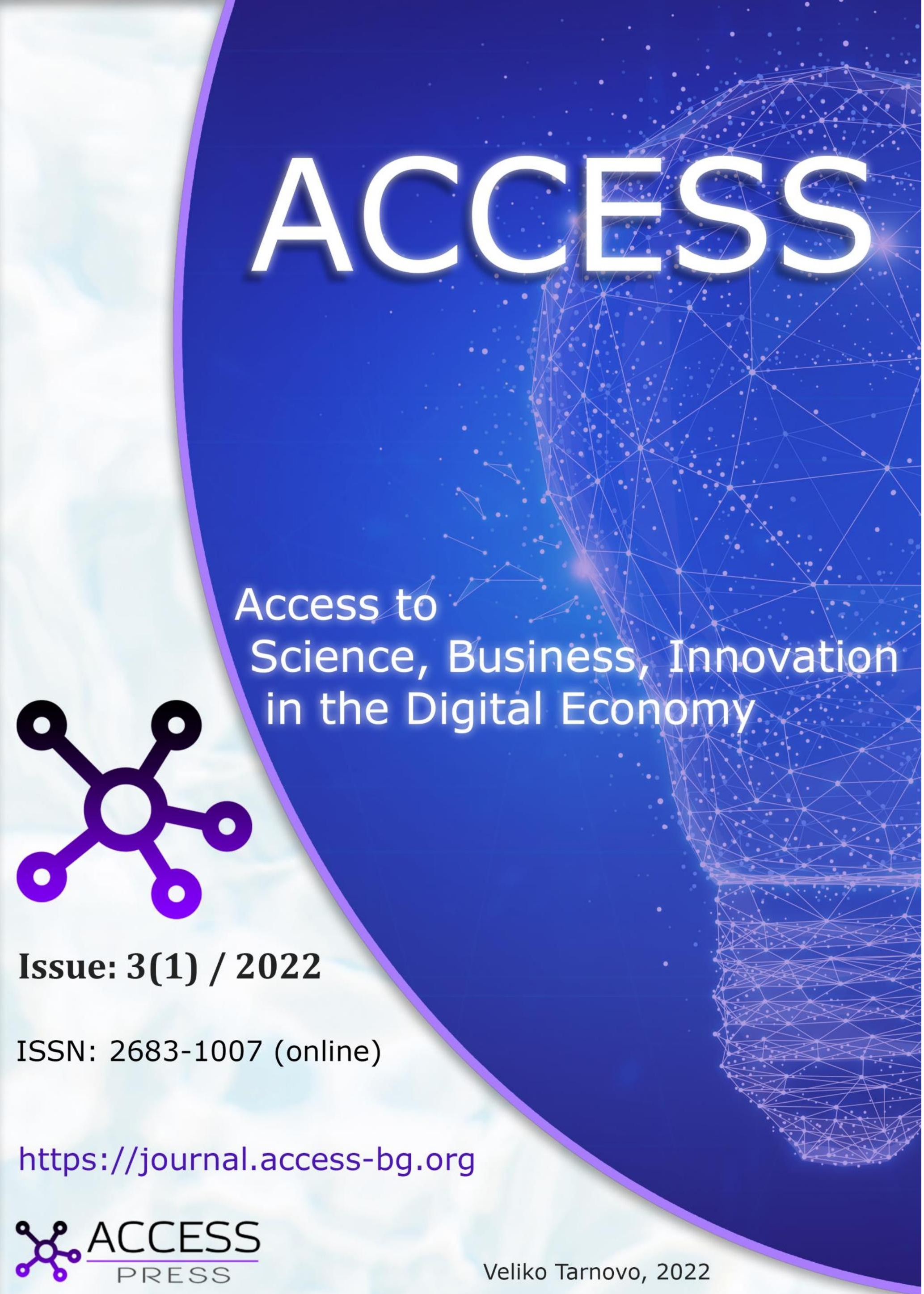




\section{ACCESS Journal:}

Access to science, business, innovation in the digital economy

ISSN 2683-1007 (online)

http://journal.access-bg.org
2022, Volume 3, Issue 1, January https://doi.org/10.46656/access.2022.3.1

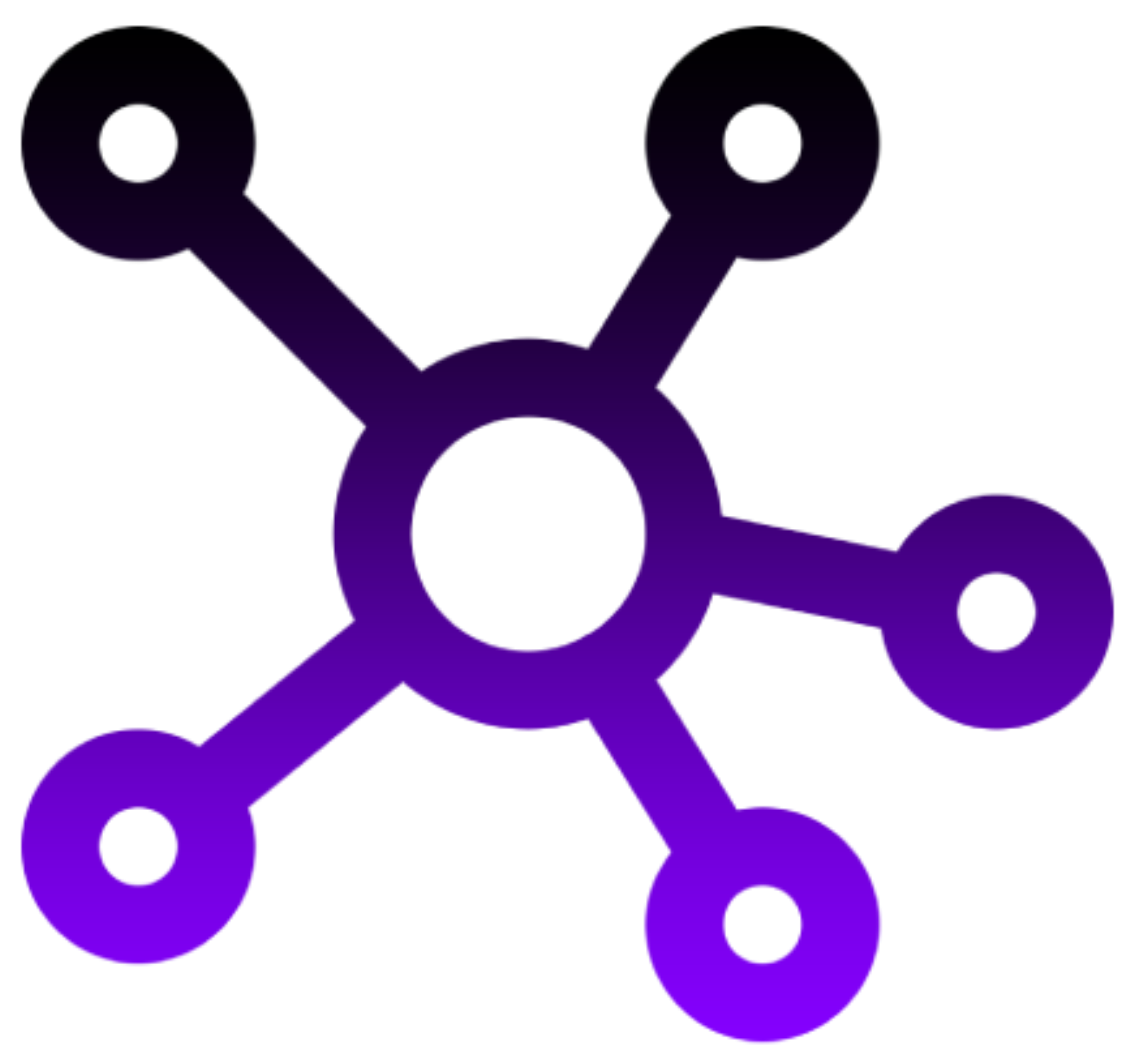

\section{Publisher:}

Publishing House "ACCESS PRESS" , Bulgaria, 2022

32 Aleksandar Burmov Str., 5000 Veliko Tarnovo, Bulgaria

Email: office@access-bg.org

https://access-bg.org

ACCESS JOURNAL 
ACCESS: Access to science, business, innovation in digital economy is a peerreviewed international scientific journal, which publishes original research papers and case studies.

The Journal is designed for publishing articles includes but is not limited to the following fields of research:

Challenges of economic development of society Innovation of the economy and enterprises, start-up activities

Risk, risk management, risk financing instruments

Finance and financial markets

Market mechanisms of entrepreneurship development

Technological Changes Management and Economic Development Management Innovation management

Management of the national and international economy

Regional competitiveness through investment efficiency

Business, Strategy and Investional Management

Management Science and Information Systems

Educational Management Challenges in Digital Environment

Global Management of Social Issues in Digital Economy

Sustainable social and economical environment of business development

Sustainable enterprise; State sustainability

Innovation on Implementation and Protection of Human Rights in Digital Environment Innovation and technologies on the Intellectual Property rights in Digital Environment Information, innovation and nonlinear modeling technologies, forecasting and management of processes and systems;

Cognitive modeling and management decision making in poorly structured systems. (Fuzzy cognitive modeling)

Artificial intelligence systems and technologies.

Robotics; Digital Economy.

INDUSTRY 4.0.; Industrial Internet of Things( "IOT" for I). 
Access Journal is included in The National Reference List

National centre for information and documentation
(NRL) of contemporary Bulgarian scientific publications with scientific review, maintained by the Minister of Education and Science through the National Center for Information and Documentation, Ref №: 3818

All papers published in the ACCESS Journal: Access to science, business, innovation in digital economy are listed, indexed and abstracted in:

Advanced Science Index, BASE, CiteFactor, Crossref, Dimensions, DRJl, EconPapers/RePEc (Research Papers in Economics), eLybrary, ESJI, EuroPub, Index Copernicus International, InfoBase Index, International Services for Impact Factor and Indexing (ISIFI), ISSUU, Google Scholar, Polska Bibliografia Naukowa (portal of the Polish, Ministry of Science and Higher Education), ResearchBib, Root Indexing, Scholar Steer, Scilit.

\section{https://doi.org/10.46656/access}

ACCESS: Access to science, business, innovation in digital economy, 2022, 3(1)

Printout: 3 issues per year. Issue 1 (January); Issue 2 (May); Issue 3 (September).

Please, send your comments and opinions at: editors@access-bg.org

EDITORIAL CORRESPONDENCE including manuscripts and submissions:

Prof. DSc. Mariana Petrova

e-mail: submissions@access-bg.org or m.petrova@access-bg.org

This is an open access journal and all published articles are licensed under a Creative Commons Attribution 4.0 International License 
EDITORS-IN-CHIEF:

Mariana Petrova, St.Cyril and St.Methodius University of Veliko Tarnovo, Bulgaria e-mail: $\underline{\text { m.petrova@ts.uni-vt.bg }}$

\section{EDITORIAL BOARD MEMBERS:}

Ludmila ALEKSEJEVA, Daugavpils University

Daugavpils LV

Alina BADULESCU, University of Oradea Oradea RO

Iurie CARAUS, University of Montreal

Montreal CA

Manoj Kumar CHAUDHARY, Tribhuvan University

Kathmandu NP

Francesca DI VIRGILIO, University of Molise

Campobasso IT

Deniss DYAKONS, ISMA University

Riga

LV

Liudmyla DOROKHOVA, National University of Pharmacy

Kharkiv

Badri GECHBAIA, Batumi Shota Rustaveli State University

Batumi

GE

Viktor KOVAL, Odessa Institute of Trade and Economics of Kyiv National

Odessa

UA

University of Trade and Economics

Nayden NENKOV, Konstantin Preslavsky University of Shumen

Shumen

BG

Yashar SALAMZADEH, Universiti Sains Malaysia

Penang

MY

Jan-Urban SANDAL, Fil. Dr. Jan-U. Sandal Institute

Oslo

NO

Ludmila STEMPLEWSKA, Vistula University, Vistula Academy of Finance and

Warsaw

PL

Business in Warsaw

Olena SUSHCHENKO, Simon Kuznets Kharkiv National University of Economics

Kharkiv

UA

Gonca TELLI, Dogus University

Istanbul

TR

Nguyen Van TRU, Information business software consultancy (IBC)

Singapore

SG

Talgat UTEUBAYEV, L.N. Gumilyov Eurasian National University

Ho Chi Minh

$\mathrm{VN}$

Radostin VAZOV, VUZF University (Higher School of Insurance and Finance)

Nur-Sultan

KZ

Sofia

BG

Ludmila ZAKONNOVA, T.F. Gorbachev Kuzbass State Technical University

Kemerovo

RU

\section{SCIENTIFIC COUNCIL}

Sultan RAMAZANOV

Chairman of the Scientific Council

Ryszard PUKALA

Co-Chairman of the Scientific Council

Yuriy DYACHENKO

Ketevan GOLETIANI

Janis GRASIS

Nurlan KURMANOV

Karim NAAMA

Evgeny ZHERNOV
Vadym Hetman Kyiv National Economics University, Kyiv

UA

Bronislaw Markiewicz State Higher School of Technology and Economics, Jaroslaw (PWSTE)

Volodymyr Dahl East Ukrainian National University,

Severodonetsk

Batumi Navigation Teaching University

Riga Stradins University, Riga

L.N. Gumilyov Eurasian National University, Nur-Sultan $\quad$ KZ

St. Cyril and St. Methodius University of Veliko Tarnovo BG

T.F. Gorbachev Kuzbass State Technical University, Kemerovo
GE

LV

PL

UA RU 


\section{Dear Readers, Authors, Reviewers of Journal ACCESS!}

This is the first issue of the journal "ACCESS: Access to science, business, innovation in digital economy" for the calendar year 2022 and the 6th Issue of the journal!

On behalf of the Editorial Board and the Scientific Council of the journal, we wish you a healthy, peaceful, controversial and creative year 2022!

The New Year is a time for looking back and for looking forward.

In modern conditions of coronavirus pandemic, instability, systematic crises and significant turbulence, the modern world is experiencing global transformations.

Today, humanity has realized the threat posed by natural disasters, natural and man-made disasters, conflicts in society, wars and the like.

Covid-19, as every crisis, not only creates difficulties and discomfort, but also opens up new opportunities, the new situation provokes a number of questions for scientific discussion, which the journal undertakes to offer to the public attention.

A deep systemic crisis in which the world community in general and the countries of the former Soviet Union (CIS) in particular are forcing to rethink many strategies, approaches, methodologies, plans and hopes. This is a turning point, a moment of truth, a turn to look back and look to the future.

In the current century, only those countries that have embarked on an innovative path of development and build a knowledge-based economy are developing steadily. The experience of leading countries, the first to embark on this path and form a post-industrial society today, shows the need for scientific study of a set of practical problems, deep understanding of processes in socio-economic systems, formulating a precise and clear goal, political decision-making and consistent implementation. Innovation development mechanisms developed by leading countries have been adapted and successfully used in many developing countries. They are used to ensure the transition from the resource and investment stages of technological development to the stage based on innovative technologies. But in none of these countries has there been a direct transfer of world experience in translating the economy to an innovative path of development. Each time the social and economic features, resource, territorial, labor, intellectual potential and competitive advantages of the country were taken into account.

The application of innovative, synergetic, cybernetic and mathematical methods and models in economics to analyze the processes of risk, security, crisis and catastrophe, as well as the development of methodology, methods and models of decision management in economic, environmental and social systems is relevant. At the same time, innovative development is the main way out of the crisis.

The integral goal and main idea of this journal is to be a place for discussions and sharing information, create a general concept, principles, methodologies, methods, models and information technologies and management decision-making systems under conditions of uncertainty, risk, danger, instability and crisis for sustainable and viable economic systems, projects of ecological economy.

The potential of modern science must be used to prevent natural disasters, catastrophes, conflicts, wars and other emergencies. It is necessary to create an international approach to the problem, which can be called risk theory, on the basis of which risk management is possible. There is an urgent need in the world today to anticipate emergencies and mitigate their consequences. The task is to create a new paradigm in the field of hazard or risk management, and to build a mathematical theory of safety and risk based on nonlinear dynamics and computer modeling. On the basis of systems analysis and nonlinear dynamics, patterns of catastrophic behavior of most complex systems in the field of technosphere, economy and the like can be identified.

New technologies are interdisciplinary. They require, on the one hand, knowledge of man and are based, of course, on knowledge of man. On the other hand, they represent a specific forecast and design methods, which implies a quantitative description, the use of formalized models and methods of applied mathematics. On the third hand, they require a holistic description of the object, its relationship with the biosphere, technosphere, with scenarios of technological development. To do this, we must rely on a solid foundation of science.

Over the past years, processes of technological transformations have been taking place, which allow moving to a qualitatively new level of business technologies, which gives reason to talk about the onset of 
the so-called cognitive era. Under these conditions, new management technologies and approaches to management are developing, in particular, cognitive management.

The current stage of development of knowledge-intensive enterprises (HBs) is characterized by qualitative changes in the types of socially significant human activity: labor, characteristic of an industrial society, is replaced by creativity in a post-industrial society. Machine technology is giving way to "smart technology". As a result, knowledge and information become the leading factors of production, which leads to a decrease in the role of material factors of production. The cardinal changes in production relations led to special requirements for the quality of human resources, highlighting the intellectual component in them and making them an independent factor of production.

Here the list of new scientific, technical and technological problems that have arisen could be continued, but this is in subsequent issues.

The indicated issues of debatable nature are on the agenda in Europe and the world, and require the involvement of scientists and practitioners in finding the right solutions to the global challenges.

In 2021, we continued to promote and index the journal "Access to science, business, innovation in digital economy", and it will be listed by more academic databases in the future.

We are convinced that the achieved publication rating of the journal in international databases, as well as its renewed editorial board, which includes famous scientists nationally and internationally, raise the prestige of the journal and increase the quality requirements of its content.

Receiving such recognition is unthinkable without the dedicated work of the journal's team and all its supporters and friends.

We would like to thank the authors who present scientific articles of both theoretical and empirical content, representing scientific and practical interest in all areas of economic science.

By the end of 2021 we have already had 67 authors from 35 organizations from Bulgaria, Georgia, Kazakhstan, Latvia, Nepal, Norway, Poland, Russian Federation, Ukraine, Yemen. We have new authors joining us from Azerbaijan, Uzbekistan

We hope that through the involvement of scholars and practitioners from many institutions of high international prestige, as well as through a peer review process, the editors will be able to ensure the continued high standard of this journal.

We would like to thank the members of the editorial board for their indisputable competence, scientific rigor and dedication to create and promote a network of scientific communities in the profile of the journal and promoting scientific research!

We are also grateful to the reviewers for the analytical and well-intentioned motivating reviews!

Wishing you, your families and friends the very best in the coming year!

Have a fruitful, healthy and happy 2022 !

Stay heath and take care!

With best regards,

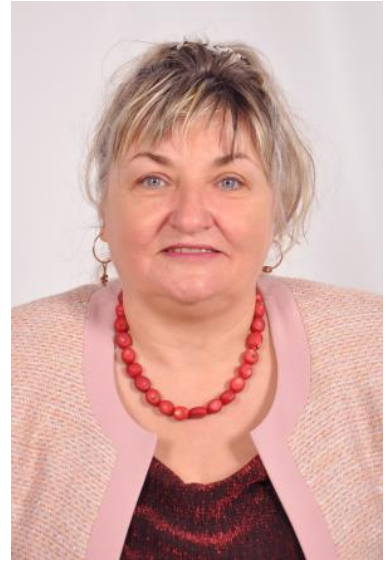

Editor-in-Chief

Mariana
PETROVA

D.Sc. in Physics and Mathematics St. Cyril and

St. Methodius University of Veliko Tarnovo, Bulgaria
Chairman of the Scientific Council

\section{Sultan RAMAZANOV}

D.Sc. in Economics, D.Sc. in Technology, professor

Vadym Hetman Kyiv National Economics University, Kyiv, Ukraine

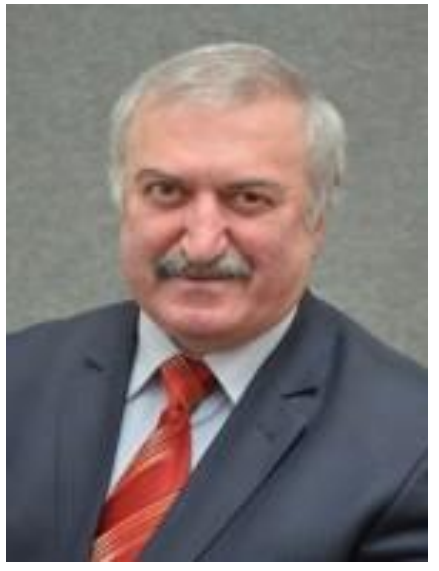




\title{
PANDEMIC ERA AND ITS IMPACT ON THE INVESTMENT AND BUSINESS ENVIRONMENT -GEORGIAN CASE
}

\author{
Nana Shonia ${ }^{1}$, Zurab Mushkudiani $^{2}$, Maia Siradze ${ }^{3}$ \\ ${ }^{1}$ Akaki Tsereteli State University, Kutaisi, Georgia \\ ${ }^{2}$ International Teaching University of Management and Communication "Alterbridge", Tbilisi, Georgia \\ ${ }^{3}$ Georgian Technical University, Tbilisi, Georgia
}

e-mails: ${ }^{1}$ nana.shonia@atsu.edu.ge, ${ }^{2}$ z.mushkudiani@bntu.edu.ge, ${ }^{3}$ siradzemaiko777@gmail.com

Received: 20 October 2021 Accepted: 07 November 2021 Online Published: 02 January 2022

\begin{abstract}
In the modern world, which is experiencing more globalization, the entrepreneurship and its development are important. Business at the modern stage is one of the most promising areas to stimulate the economy, business support and its perfection should be one of the main priorities of the state, because as a result of its development the country develops both economically and socially.

Objectives: To clarify what kind of impact did the pandemic have on previously mentioned issues and what were other development hindering factors. A study was conducted to analyze the situation of small and medium business sectors, which aims to identify the problems that Georgian entrepreneurship is facing today

Methods/Approach: Both qualitative and quantitative studies carried out in business sector in Georgia

Results: The results gained within the study and further recommendations significantly define the role of small and medium-sized business sectors for Georgia. The paper gives us a clear conception on the current situation and enables us to make relevant conclusions based on the obtained results.
\end{abstract}

Keywords: COVID-19, business environment, investment, entrepreneurship, pandemic.

JEL classification: H25, H26, L21, L26, M54

Citation:

Shonia, N., Mushkudiani, Z., Siradze, M. (2022). Pandemic era and its impact on the investment and business environment Georgian case. Access to science, business, innovation in digital economy, ACCESS Press, 3(1): 7-15. https://doi.org/10.46656/access.2022.3.1(1)

\section{INTRODUCTION}

The consequences of the coronavirus disease (COVID-19) outbreak are unprecedented and felt around the world. The world of work is being profoundly affected by the pandemic. In addition to the threat to public health, the economic and social disruption threatens the long-term livelihoods and wellbeing of millions (Gigauri I, \& Guruli, 2020, 2021). The pandemic is heavily affecting labor markets, economies and enterprises, including global supply chains, leading to widespread business disruptions (Bartik., Bertrand, Cullen, \& Glaeser, 2020). 
The global pandemic is rapidly reshaping organizations as they adapt to a new business environment with new automation needs and changes in human behavior (customers, employees, partners and others) (Fairlie, 2020). The biggest concerns relate to health $\&$ safety as well as uncertainty around the duration of the situation. Businesses need to prepare to handle these uncertain times as best as possible and find ways to create opportunities from this crisis. Many small to mid-sized organizations are reviewing their go-to-market strategies and processes, looking at initiatives across functions including finance, HR, supply chain, services sales and marketing. For businesses to operate efficiently and realize their revenue (Mushkudiani, \& Gechbaia, 2019), every function needs to be tech enabled. The finance department has likely started implementing digitally signed invoices, employee claims are no longer paper-based, purchase orders are issued electronically, and vendor payments done online. The customer care/services team is hard pressed to provide online help guides, chat bots enable real-time collaboration to resolve customer issues (Koberidze, \& Dadvadze, 2015). These tools were always available, but the recent situation has triggered increased adoption and implementation. Automation can play a role for any process/sub-process that previously required physical documentation or human intervention for completion.

In the process of economic development, special importance is given to the business, which aims at further improvement of the entrepreneurial environment, that will facilitate the growth and development of small and medium enterprises (Erkomaishvili G., Gigauri L.,\& Talakhadze N, 2017) supporting the development of the private sector and especially entrepreneurship plays an important role in terms of the socio-economic development strategy of Georgia.

There is still no uniform standard for defining the small and medium businesses, the only thing, that is agreed by all researchers is the maturity of the small enterprise production, imperfection of quantitative and qualitative peculiarities, especially in developing countries (Parker, 2018) Despite the implementation of the support policy for the small business development represents the key EU requirement for partner countries, Georgia, as an EU associated country is also required to strictly adhere to European Standards. It should also be noted, that despite the annual growth of the economic scale in Georgia, the small business sector reveals unsatisfactory development trends.

\section{METHODOLOGY}

The quantitative and qualitative methods were used while compiling the study, where several business representatives in their companies were interviewed. We conducted the study on the available information that was published on the social pages of the National Bank and the Ministry of Finance. The article describes the current situation of the business as well as compares its functioning before the pandemic era. Consequently, the information is reflected in percentages and the diagram is made according to the methods. 


\section{RESULTS and DISCUSSION}

In order to identify the business entrepreneurship and related problems, we carried out a study and results are presented below in detail. The goal is the basic problems that are faced by the entrepreneurs while doing the business. We tried to contact several business representatives for study, including wine producers, managers, who produce fizzy drinks as well as juice, etc. It was turned out, that the most hindering environments in terms of business development are related to innovations, technologies, higher education and training environment and the financial markets development. These barriers are particularly painful for small and medium business development and eventually affect the quality of their involvement in the markets.

However, it's worth to note, that among the above mentioned problems, there is another serious problem, that also inflicts a great harm to entrepreneurship. During the pandemic, it became necessary not to develop the small and medium businesses, but to commence and maintain them even more. Currently, Georgian companies are facing serious challenges, as the COVID -19 causes serious damage to all businesses. In order to give more clarity to our study, we present an example of one of the companies (anonymity is preserved), that is engaged in wine production. 100 people participated in the study, the age of 51,2\% of respondents range from 20 to $25,32,5 \%$ are from 25 to 40 years old, $8,2 \%$ up to $40-45$ years old and $8,1 \%$ above 45 years old.

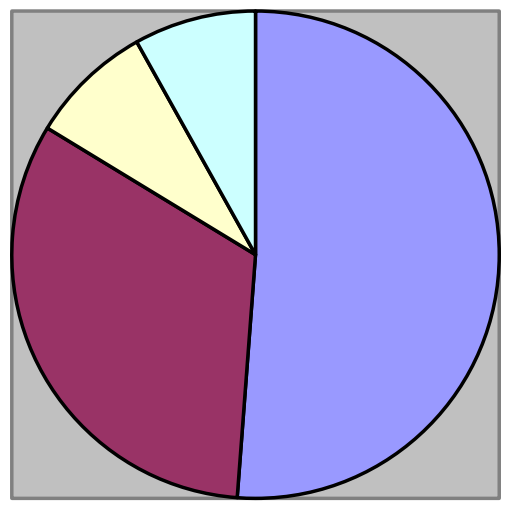

\section{पup to $20-25$ \\ 口up to $25-40$ \\ $\square$ up to $40-45$ \\ 口above 45}

Figure 1. Age of employees in the business sector

Source: Own compilation

Pursuant to this data, we can conclude, that the younger generation was more interested in the study, that indicates their involvement in similar studies.

The most of the respondents, i.e. $35 \%$ are with bachelor's degree, $50 \%$ with secondary education, $7 \%$ with master's degree and $2 \%$ with PHD, and the remaining $6 \%$ have incomplete secondary education, based on this data we can assume, that the younger generation is more interested in similar studies. 


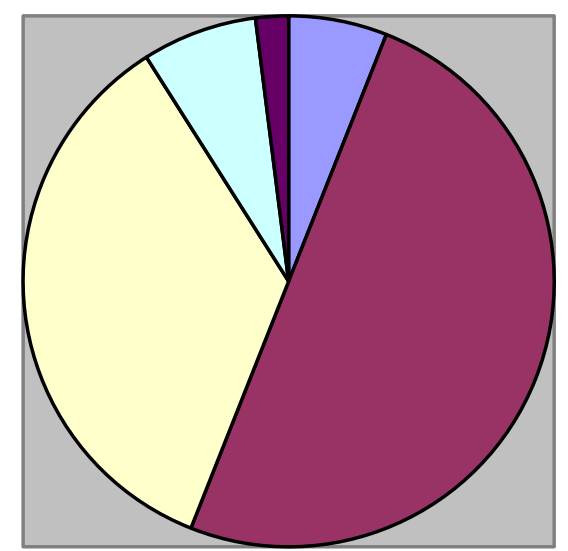

口Incomplete secondary
$\square$ Secondary
$\square$ Bachelor
$\square$ Master
$\square$ PHD

Figure 2. Education of employees in the business sector

Source: Own compilation

The majority of respondents named several issues that hindered their businesses to develop. All these are added by the fact that the state bans $90 \%$ of these businesses from operating to prevent the spread of a pandemic. Some issues have emerged that need to be paid a lot of attention in the current COVID-19 era, because the development of business and the world economy requires the functioning of the following factors, such as:

-Availability of foreign currencies;

- Improvement of investment and entrepreneurial environment;

- Export facilitation;

- Improvement of tax policy and etc.

The restrictions imposed to prevent the spread of the pandemic, increased vagueness, and reduced demand in the financial sector increased the risks. The focus is made on the financing of companies by banks. Despite the sustainable level of the total debt of the companies, the vulnerability of companies to existing risks is due to the significant reliance on external sources of funding, significant relative share of short-term debt and high dollarization of liabilities as well. The regression induced due to the pandemic and vulnerability of companies in terms of the identified risks stipulate an increase in credit risk of the financial sector. The difficulties caused by increased credit risk in companies are significant for the financial sector and have an influence on to households as well. The negative impact of the pandemic is relatively strong in the event of small and mediumsized businesses. In order to maintain access to funding sources for companies, which is a prerequisite for their operation and employment, targeted anti-crisis support programs are of utmost importance.

In addition, the National Bank foresees the role of microfinance organizations in terms of providing financial services to business and population to the regions of Georgia, so it provides liquidity support with additional swap operations along with the standard refinancing loans which will be available to microfinance 
organizations in addition to banks. The term of swap operations is defined for 1 month, with the right to monthly renewal for the next 1 year. The National Bank, in the current situation and after the end of the pandemic, when the economic life is back to normal, will traditionally ensure the existence of an adequate level of liquidity in the financial system and in the whole economy as well.

The second problem that hinders the operation of the business is the obstruction of the investment and entrepreneurial environment. Favorable entrepreneurial and investment environment significantly affects productivity as far as directly impact on the efficient allocation of resources in the private sector. Due to the fierce global competition and dynamic economic processes, business requirements are changing rapidly.

According to Geostat, the volume of foreign direct investment in Georgia amounted to 616.9 USD million in 2020, which is 52.9 percent less than the verified data of 2019. The main reason for the decrease is the transfer of several enterprises to the ownership of a resident of Georgia, which reduced foreign direct investment by 340.5 million. The diagram given below shows the dynamics of foreign direct investment in Georgia in 2014-2020. Foreign direct investment is characterized by stable decline in recent years. For example, in 2019 and 2020, about 1/3 less investment was made compared to 2018. It clear that the current situation of the world is reflected in the general investment climate.

Table 1. Dynamics of Foreign Direct Investment in Georgia

\begin{tabular}{|l|c|c|c|c|c|}
\hline Year & I & II & III & IV & Total \\
\hline 2014 & 331,9 & 217,6 & 749,5 & 538 & 1837 \\
\hline 2015 & 343,4 & 493,2 & 531,1 & 361 & 1728,8 \\
\hline 2016 & 392,6 & 452,4 & 507,4 & 300,2 & 1652,6 \\
\hline 2017 & 413,2 & 395,7 & 634,8 & 534,6 & 1978,3 \\
\hline 2018 & 328,6 & 406,1 & 365,4 & 206,2 & 1306,3 \\
\hline 2019 & 313,7 & 236,6 & 396,0 & 364,5 & 1310,8 \\
\hline 2020 & 175,0 & 241,3 & 303,3 & $-102,8$ & 616,9 \\
\hline
\end{tabular}

Source: Own elaboration based on National Bank of Georgia

If we look through the data of mainly developed countries abroad, we will notice that more than half of the GDP of these countries fall to small businesses. It is enough to mention, that currently, $50-52 \%$ of the GDP are produced via small business in the USA and Germany, 52-54\% in Japan, 56-62\% in France, 50-53\% in the UK, $57-60 \%$ in Italy, 63-67\% in the EU. This sector produces and sells large scale products for entrepreneurial purposes and wide variety of services. Works related to different types of services are performed as well.

Export promotion is a crucial factor in production. Georgian companies try their best to export their products in foreign markets, which is certainly associated with considerable risks. Exports promotion and development mainly includes: connection of foreign buyers with Georgian 
producers/manufactures, organizing trade missions, providing information on existing exports procedures in Georgia, providing information to clients on existing custom tariffs in foreign markets, etc. The impact of the pandemic is certainly felt here as well, in particular: Georgia has close economic relations with the European Union, which represents $1 / 3$ of the export market.

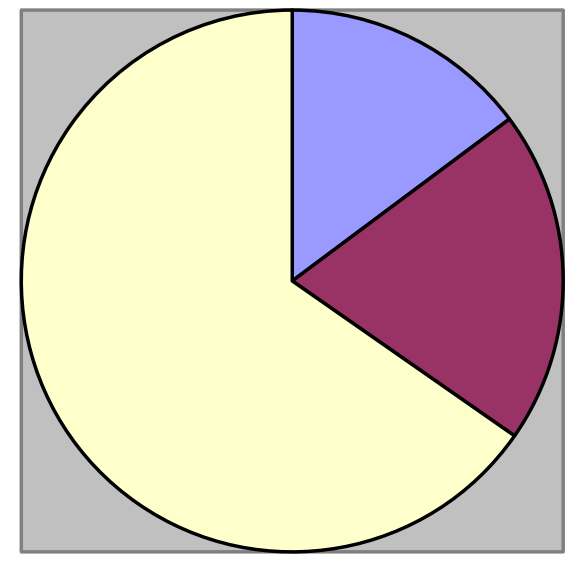

\section{$\square$ China}

$\square$ Azerbaijan

$\square$ Russia

Figure 3. Export abroad in 2019.

Source: Own elaboration based on National Statistics Office of Georgia

The share of Azerbaijan is important in terms of the export and movement toward this country was restricted (17.2\% of exports in January-February, 2020), the share of China in export, despite the fact that coronavirus outbreak had already started in this country in January-February, is also large and amounts $12.4 \%$.

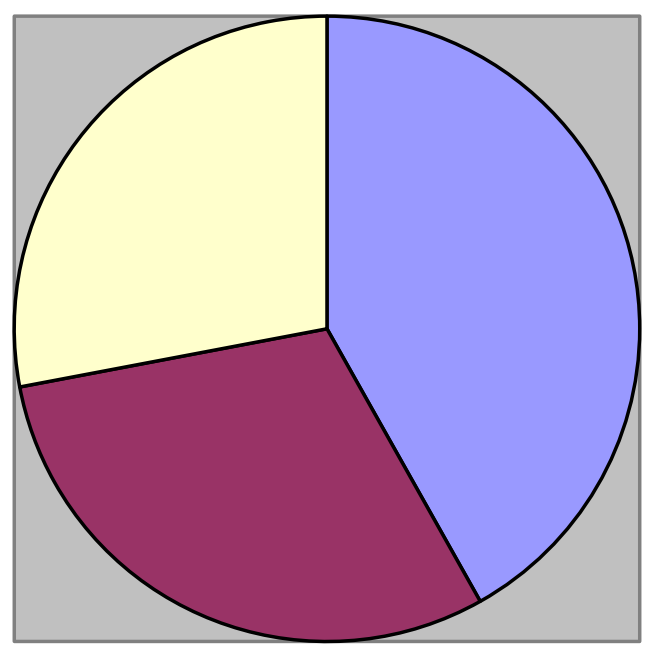

$\square$ Azerbaijan
$\square$ China
$\square$ Russia

Figure 4. Export abroad in 2020.

Source: Own elaboration based on National Statistics Office of Georgia 
And Russia is in the third place, the export share of which in the same period of time was $11.5 \%$, while export share was getting more and more less in other countries.

Agriculture is an important part of industrial production and local exports. In particular, wine exports. As of January-March of this year, 43.7 million Gel worth wine export was carried out, which amounts to $7.2 \%$ of local export. The above mentioned is less than 0.4 million USD compared to the same period of last year. Pursuant to the data of the Ministry of Finance, in January and February 2020, the export of Georgia decreased compared to the data of the previous years of the same period. In January the difference was only $0.46 \%$, but already in January the export of Georgia significantly decreased by 17.9\%. In February, the COVID-19 was widespread throughout the world. The decline in Georgian export can be assumed to be conditioned, at least in part, due to the world trade reduction.

Improvement of tax policy was named as one of the issues as a result of the study. With regard to Covid19 , reduction of the physical relationship between employees and customers / payers is the most important requirement in terms of the safety. Tax refunds and financial assistance are potentially very important services because both individuals and companies may need help to save themselves and carry on with business. Other services related to, for example, customs security and control should be maintained, though less severity may be allowed temporarily. In addition, in order to cope with the crisis, the timely implementation of measures developed by governments to assist individuals or businesses is of utmost importance.

It is necessary to reduce liabilities for taxpayers, to extend deadlines for submission of tax declaration and tax payment with clear instructions to which taxes and taxpayers the established term apply and to what period as well. Tax administrations of those countries with a high level of electronic filing of tax declarations may consider extending the deadline only for the payment of taxes, i.e. tax declarations will be submitted within the usual, established timeframe, taxpayers shall be allowed to reduce their current income and profit payments, considering the expected reduced revenues of this year. Mitigation/facilitating measures for terms and conditions established for tax debt payment, in times of crisis, to identify necessary and additional / new work processes and redistribute resources from non-essential operations to necessary operations. Extension of the term for submission of documents related to cargo and postponement on import. Also, receiving documents submitted without signature and seal. Enabling electronic submission of the documents if possible.

\section{CONCLUSION}

Business development and assessment of the current situation as well as research are important for any developed or developing country, including Georgia. Thus, it was established that in order for their business to be effective, the business must have a stable environment, which requires appropriate steps by the state. Programs focused on the mentioned business sector, regulatory bodies, fewer barriers, support, if necessary, etc. This is a short list of things that need to be regulated for small and medium businesses. A study was 
conducted to analyze the situation of the business sector, which aims to identify the problems that Georgian entrepreneurship is facing today and to develop ways to improve the situation of the business sector in Georgia.

It was also revealed that, despite the global recognition of small entrepreneurship as the most important sector, not all opportunities are used for its full development in Georgia. Enhancement of small business support shall be a crucial part of the state economic policy, which can be implemented through state regulation of small business development, particularly, with macroeconomic regulation. Systematic, targeted work shall be carried out in direction of constant perfection of the legislative framework, in order to thoroughly stimulate the development of effective priority, public and social directions of small economy.

\section{Conflict of interests}

The authors declare no conflict of interest.

\section{References}

Bartik, A. W., Bertrand, M., Cullen, Z. B., Glaeser, E. L., Luca, M., \& Stanton, C. T. (2020). How are small businesses adjusting to COVID-19? Early evidence from a survey. NBER Working Paper No. w26989.

Dadvadze D. (2015). "Using the International Experience of State Support for Small Business in Georgia: Problems and Perspectives". Tbilisi

Erkomaishvili G., Gigauri L., Talakhadze N. (2017). "Fundamentals of Entrepreneurship", Tbilisi, Georgia

Fairlie, R. W. (2020). The impact of Covid-19 on small business owners: Evidence of early-stage losses from the April 2020 Current Population Survey. Stanford University (SIEPR) Working Paper No. 20-022, May 23.

Gigauri, I. (2020). Organizational Support to HRM in Times of the COVID-19 Pandemic Crisis. European Journal of Marketing and Economics, 3(3), pp.36-48.

Gigauri, I. (2021). Corporate Social Responsibility and COVID-19 Pandemic Crisis: Evidence from Georgia. International Journal of Sustainable Entrepreneurship and Corporate Social Responsibility (IJSECSR), 6(1), pp.30-47.

Gigauri, I. (2021). New economic concepts shaping business models in post-pandemic era. International Journal of Innovative Technologies in Economy, (1 (33)).

Guruli I. (2020). Pandemic Review: Economic Impact and Consequences for Georgia. Tbilisi, Economic Policy Research Center. Retrieved from https://eprc.ge/uploads/Covid19Georgia_geo.pdf

Koberidze Kh. (2015). Institutional Directions for Small and Medium Entrepreneurship Development in Georgia and Opportunities for Internationalization with the European Union, Tbilisi, Georgia

Mushkudiani, Z., \& Gechbaia, B. (2019). Facing the Global Competitiveness Challenge and Quality of Business Freedom in Georgia. European Journal of Economic Studies, 2(8), 131-135.

Ocheredco, O. (2020). The improvement of the investment attractiveness of industrial enterprises in the convention of the Covid-19 pandemic. Access to science, business, innovation in digital economy, ACCESS Press, 1(2): 131-145, https://doi.org/10.46656/access.2020.1.2(5)

Parker, S. C. (2018). The economics of entrepreneurship. Cambridge, UK: Cambridge University Press.

Ministry of Finance of Georgia (2020) Retrieved from: https://www.mof.ge/images/File/Covid-19/draft\%20_COVID19_ESCP_ENG.pdf [accessed 20 May 2020]

National bank of Georgia (2020) Retrieved from: https://nbg.gov.ge/publications/financial-stability-reports [accessed 20 May 2020]

National Statistics office of Georgia (2020) Retrieved from: https://www.geostat.ge/en/single-archive/3348\# [accessed 20 May 2020] 


\section{About the authors}

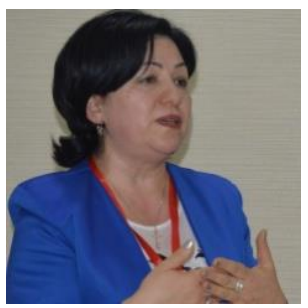

\section{Nana SHONIA}

Doctor of Economics, Professor, Dean of Business, Law and Social Sciences faculty, Akaki Tsereteli State University, Georgia. Research interests: Macroeconomic, finances and banking, management and higher education. She has supervised numerous master's and doctoral theses at Akaki Tsereteli State University and taught classes on research methods. She has been taking participation in different international and local conferences.

ORCID ID: https://orcid.org/ 0000-0001-7689-3800

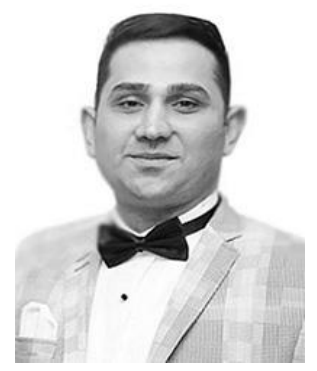

\section{Zurab MUSHKUDIANI}

Leading researcher and Professor at Batumi Navigation Teaching University and International Teaching University of Management and Communication Alterbridge. He received his $\mathrm{PhD}$ from Akaki Tsereteli State University in 2015 and has worked on plenty of local and international educational projects. Also, he worked in Kutaisi City Hall as a PR senior specialist and maintained relationship with public. His specialties are Management, Finance and Education. ORCID ID: https://orcid.org/0000-0003-0987-3564

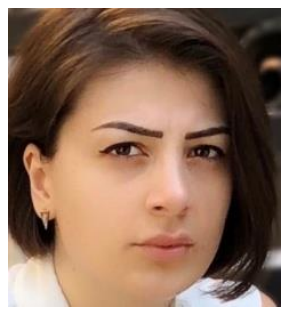

\section{Maia SIRADZE}

PhD student at Georgian Technical University.

She obtained her master's degree from the University of Akaki Tsereteli. Her research interests include, entrepreneur, finances and management. She has been taking part in different scientificpractical conferences.

Copyright ( 2020 by author(s) and ACCESS Publishing Press This work is licensed under the Creative Commons Attribution International License (CC BY) 


\title{
THE USE OF INFORMATION SYSTEMS AS A WAY TO ENSURE INTERACTION BETWEEN SMALL AND BIG TOURISM ENTERPRISES
}

\author{
Svitlana Labunska ${ }^{1}$, Oleksandr Zyma², Serhii Sushchenko ${ }^{3}$ \\ ${ }^{1,2,3}$ Simon Kuznets Kharkiv National University of Economics, Kharkiv, Ukraine \\ e-mails: ${ }^{1}$ svetlana.lab@gmail.com, ${ }^{2}$ zima@ @neu.edu.ua, ${ }^{3}$ sergsushchenko@gmail.com
}

Received:20 November 2021 Accepted:27 December 2021 Online Published:05 January 2022

\begin{abstract}
The article is devoted to the information systems application in the sphere of small and big tourism enterprises interaction ensuring. The current role of information technologies due to their specific properties in the field of technical development of tourism as well as in the process tourism enterprises interaction ensuring is actualized. The advantages and features of the use of current information systems and technologies, in particular, global distribution systems, computer reservation systems, in the tourism enterprises business activity, which allow to ensure their effective interaction, are highlighted. The stages of the information technologies implementation in the tourism industry are determined. Taking into account the tourism industry specifics and the peculiarities of the information systems use in the tourism market business-entities activities, the authors determined the essence of the small and big tourism enterprises integrative interaction. The main global distribution systems used in the current tourism industry market are analyzed. The main actors controlling the global distribution systems' sector in the world are distincted. A comparative analysis of the main global distribution systems' conditions of use and maintenance is carried out. The main advantages of the global distribution systems, their use in the process of small and big tourism enterprises interaction ensuring are identified, and the prospects for their further development are shown.
\end{abstract}

Keywords: information systems, enterprise, interaction, tourism, GDS.

JEL classification: $L 83, L 86, Z 32, O 10$

Citation:

Labunska, Sv., Zyma, O., Sushchenko, S. (2022). The use of information systems as a way to ensure interaction between small and big tourism enterprises. Access to science, business, innovation in digital economy, ACCESS Press, 3(1): 1628. https://doi.org/10.46656/access.2022.3.1(2)

\section{INTRODUCTION}

The tourism industry market is becoming increasingly global. The world as a global space has been particularly influenced by the information technology dramatically development. For the currently society development, the role of information technology is strategically important, and its importance is growing rapidly. Information technologies make it possible to activate and efficiently use the information resources of the society. Effective use of information resources - scientific knowledge, discoveries, inventions, technologies, best practices - allow you to get significant savings in resources. 
In most developed countries, the level of business activity is increasingly determined by the processes of information generation, storage, processing and transferring. Therefore, business structures are forced to master and practically use information technologies corresponding to these processes. Information processes are an essential element of all complex industrial or social processes. The tourism industry is no exception. Information technologies have begun to play a significant role in the all tourism enterprises' business activities and interactions, regardless of their size and transaction volume. As a result, all enterprises, regardless of their size, product offering, and geography, have gone through major redesigning business processes. Now information technologies play an important role in the technical development of tourism, determined by a number of specific IT properties (efficiency and availability), as well as in the tourism enterprises' interaction ensuring processes. Thus, the use of information systems and IT in the process of small and big tourism enterprises interaction ensuring requires appropriate theoretical, methodological, and scientific support.

\section{BRIEF LITERATURE REVIEW}

The rapid development of information systems and technologies has fundamentally changed the tourism industry's functioning principles and architecture (Werthner \& Klein, 2005; Laverty, S., 2014). The Computer Reservations Systems (CRS) and Global Distribution Systems (GDS) introduction have transformed the operational practices in the tourism and in particulary in the airline industries dramatically (Buhalis, 2004; O’Connor, 1999; Emmer et al, 1993; eBusiness Watch, 2006; Constantinos et al, 2020).

The theoretical basis taking into account the small and big enterprises interaction aspects, its informational and economic ensuring developed in the scientific writings such as Porter, M. (1980), Varnaliy, Z. (2015), Sushchenko\&Trunina (2016), Todorova (2018A, 2019).

The issues of the tourism enterprises development, their informational support, and ensuring are receiving a lot of attention nowadays (Petrova et al, 2018; Lukjanova\&Odinokova, 2020; Chairoel et al, 2015; Marinov \&Todorova, 2020; Todorova, 2017; Todorova, 2018B). However, the issues of the information systems use as a way of small and big tourism enterprises interaction ensuring, their peculiarities essential research needs to.

\section{The purpose of the paper}

Despite the fact that information systems and ICT are currently a prerequisite for the tourism enterprises' stable development, many aspects of their use remain unrevealed. Insufficient knowledge of methodological and practical tools for the information systems and ICT implementation in the tourism enterprises operating activities are often the reasons that prevent companies from the higher level of development, and the use of small and big tourism enterprises interaction opportunities. The aim of the study is to critically analyze the benefits of the information systems and technologies' implementation in the tourism industry and to determine the possibilities of their use as a way of small and big tourism enterprises' interaction ensuring. 


\section{RESULTS and DISCUSSION}

Tourism business automation is closely related to the external business information collecting and analyzing system. These processes are complex and cover all aspects of a travel company's business activity. The external business information collecting systems provide managers with data on the tourism industry market functioning. Travel companies with a sufficiently high level of organization take additional measures to increase the relevance of external business information (various ratings, statistics, information about the travel situation) by encouraging travel agents and business partners.

Since environments do appear to be changeable and chaotic, it is necessary to ensure the adaptability of the tourism enterprise for its effective functioning. High reliability and ensuring adaptability are some of the fundamental principles of the tourism enterprises stable functioning. To do this, it is necessary to develop and implement complex information systems that concentrate a set of organizational, security, technical and other capabilities aimed at achieving a sufficient level of security and business efficiency.

In practice, tourism enterprises use various types of information technologies, namely: global distribution systems; electronic information systems; information management systems; mobile communication systems; services of the global computer network Internet.

The use of modern information technologies increases the safety and quality of travel services.

Currently, tourism uses the Global Distribution Systems (GDS), which provides fast and accurate booking of tickets for transport, hotel reservations, car rental, currency exchange, booking tickets for sports and cultural events, etc. Such systems allow booking all the main components of the tourism industry, i.e. they actually form a common information system that offers distribution networks for the entire tourism industry.

The development of the tourism business becomes impossible without modern information technologies' application, which provide (Shkola, 2003):

- integration and communication;

- $\quad$ service quality improvement;

- transfer of large amounts of information;

- increasing the speed of service and efficiency of business activities;

- the ability to take into account each client individual needs;

- effective feedback.

Information technology is a concentrated expression of scientific knowledge, information and practical experience, which makes it possible to rationally organize a particular business process. They allow you to save labor, energy or material resources needed to carry out this process. The time savings achieved through the use of any type of technology can be considered as a general criterion of efficiency. The need to save time 
is primarily aimed at technologies associated with the most massive information processes. Their optimization should save the most time due to their widespread and reusable use.

A truly revolutionary stage in the informatization of society is associated with an extraordinary increase in the use of global computer networks. The Internet is developing so rapidly that the number of users and the number of information resources almost doubles every year. More than 1 billion e-mails are transmitted over the network every second (Emmanuel et al, 2018).

Networked information technologies are an integral part of today's information society. Their objectives are as follows:

- ensuring the individual users' information exchange and making the possibility of the company's distributed information resources sharing;

- $\quad$ obtaining reference, documentary and other information from various specialized information funds.

The tourism business also uses Internet technologies for its growth and development. In recent years, thousands of independent sites of travel agencies, hotels, airlines, and dozens of travel services booking systems have appeared on the Internet. International and domestic tourism is a powerful trade services industry. The tourism industry is based on: tour operators and travel agents; hospitality; transport companies; tourism goods production and sale enterprises; advertising, information support, personnel training, as well as governing bodies. Also, other industries work for tourism, for which tourism services are not the main type of activity (culture, trade, etc.) (Emmanuel et al, 2018).

Tourism is an information-intensive activity. It is a liaison center that brings together different manufacturers in the tourism industry. Information flows, rather than goods, ensure links between tourism service providers; they go not only through dataflows, but also appear in the form of services and payments (Constantinos et al., 2020).

Tourism today is a field in which the processing, use and transfer of information is a vital component of daily activities. Consequently, tourism is almost entirely dependent on the relevant photo and video content, communications, and information transfer. Services such as hotel accommodations, car rentals, package tours, and airline tickets are implemented in today's global information environment through the use of information technology, namely computer reservation systems. It is through them that the interaction of all business structures - the tourism market subjects - is carried out.

One of the indicators for assessing the country's competitiveness in the field of tourism is "readiness for information and communication technologies" (ICT). This means growing rapidly, bringing in a large number of organizations, companies and countries, and reimagining their concept of "service delivery" to transform ongoing communication into experience. One of the parts of such readiness is the introduction of computer reservation systems at tourism enterprises. 
The first step in the computer reservation systems development was the installation of a terminal in most airlines offices, which significantly improved the quality and work of the airline personnel, without reducing the number of accepted booking requests from travel agents and individuals. The next step was to create flight bookings terminals in major travel agencies. Quickly assessing the effectiveness of new booking technologies, travel agents began to demand from airlines to significantly expand such systems functionality.

As a result, the software systems initially focused on a specific airline were merged into a system that served a group of airlines, providing information not only on the availability of a flight seats but also general information on flight details, fares, as well as information on related tourism industries - online booking experience for flights, rail, hotel rooms, car rental, taxis, and transfers (Constantinos et al., 2020).

There were several stages of the IT introduction into the tourism industry (GDS, 2021):

1. creating data - increasing the efficiency of the travel companies operating activities by automating processes based on the use of information;

2. the information management systems implementation and such information technologies development that would increase the management efficiency by improving the requirements for the information transfer organization;

3. the use of strategic information systems that could improve the firms' competitiveness. Various types of integrated networks have been implemented to improve the travel agencies operation activity as well as to establish links with external organizations;

4. the networking stage through which networks were connected at all levels: local, regional, and global. The main features of the phase are improving the IT efficiency, reducing the equipment's size and cost, increasing reliability, and organizing the interconnection of terminals located in different parts of the planet.

The use of modern information systems, namely, computer reservation systems, and GDS in the current tourism enterprises activity is one of the main elements of their integrative interaction ensuring. This will allow them to move along an ascending trajectory of development, use all available resources as efficiently as possible and interact with all tourism industry market business actors through related distribution channels (Fig. 1).

Integrity is one of the parametric categories of integration that determines the properties of the integrity of interacting subjects. Due to integrity there are relations of commonality of individual components in the process of their interaction, their corresponding wholeness is created. At the same time, the most important issue is not this property emergence, but its preservation in the process of further interaction development.

That is why factors that are system-forming for the subjects of interaction, such as their heterogeneity and opposite, are considered integrative. According to this study focus, integrity is the degree of unity, the holistic community of enterprises interacting with each other through the use of information systems and technologies. 


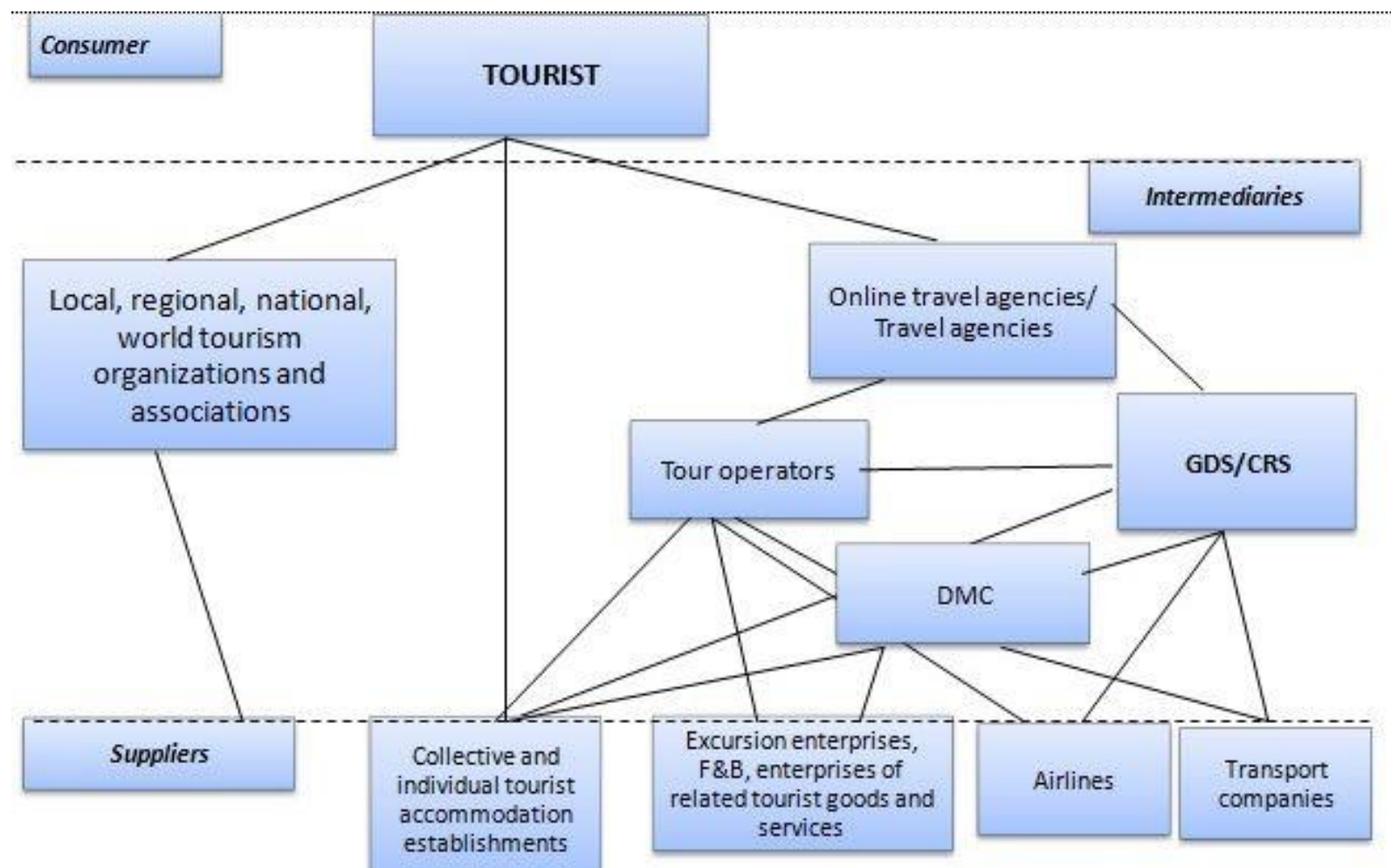

Figure 1. The tourism industry market subjects integrative interaction

The integrative interaction of small and big tourism enterprises should be understood as the organization and establishment of coherent links and joint actions of partner enterprises based on their potential's cooperative use in order to achieve common goals and economic interests with the formation of a holistic integrated system.

Travel services market is constantly evolving, e.g. tour operators creating new products by combining basic touristic services or their elements to serve the consumers. Travel agencies, as information intermediaries, provide consumers with valuable information and have the ability to book a travel product. Computer reservation systems and global distribution systems (CRS / GDS) cover flight reservation, in-flight and other relevant travel services. These systems provide the main connection with tour operators and travel agencies.

Actors on the right side of the field (Fig. 1) can be considered as an intermediate link between suppliers and consumers of tourism services. Role of the actors on the left side of the field is extremely important - they ensure all management, planning, administration, marketing and branding processes of travel destinations. They must represent the interests of all travel destination providers, but are not directly involved in the reservation process. 
Marketing and management organizations are often created by the state (government) at tourist destination level. These might be local, regional and national tourism organizations. Generating and using relevant information is a risk for a both sides of the tourism chain, i.e., for consumers and suppliers both.

Moreover, the aggreagation process of tourism services is information- intensive. The service must have clearly defined interfaces and all its aspect should be harmonized, meaning its pricing policies, terms of usage and distribution channels. This process is quite complex because the tourism product is diverse. The situation in the market of tourism services becomes more complicated as consumer behavior changes, as in other industries. As a result, the market becomes even more segmented, where each potential consumer might belong to multiple market segments at the same time (Stevenson, 2020).

The general trend in modern tourism is that tourists are looking for cheaper services, without reducing the requirements for their quality, and require more specific proposals for content and overall organization. In addition, tourists become even more mobile, but less loyal, as they compare many offers and prices. Theyy are going for more short-term trips and make subsequent decisions about them, which reduces the time between reservation and consuming (using) these services.

Great number of travel agents are relying on GDS to find the best services for their clients. And every year, more agents do realise that it's the best method to connect with airlines around the world. Now almost all tour operators represented in the Ukraine tourist services market have integrated GDS modules into their search engines. Its integration gave an opportunity to create unique service packages according to the consumer needs in the real-time mode. By using GDS, agents have access to the flight tariffs and availability, and can book seats for their clients. While the airline carefully fills in the flight report, GDS updates the search and shows the current information on the seats availability.

Many travel agents with corporate travel specialization use GDS to quickly and efficiently book seats for their clients. GDS can help airlines open new market segments to promote their products. In turn, through the GDS airlines explore new market segments of tourists that they previously could not reach.

Nowadays there are three main actors controlling the global distribution system sector - Amadeus, Saber and e-Travelport. They occupy more than $90 \%$ of the market, and the fourth participant has a share of only $6 \%$. This sector has some barriers to entry, as significant investment is needed to recreate GDS technologies (Emmanuel et al, 2018).

Amadeus Global Reservation System is the main project of the samenamed company in the field of travel services. The system is designed for reservation air tickets, cars, ferries, rail transport, hotels, cruises and insurance policies. The system is actively used by more than 400,000 professionals in the tourism industry worldwide. Today, more than 100,000 agent terminals are connected to Amadeus (TRAVELPORT, 2021).

One of the global CRSs, the Galileo system was founded in 1987 by KLM, British Airways, Swissair and Covia, they were later joined by Alitalia and Austrian Airlines. The company has about 3,000 employees and its headquarter is in Denver, Colorado, USA. Covia Airlines, which at the time had its own Apollo system, 
refocused its users on Galileo, and in 1993 the Galileo system merged with the Apollo system and became known as Galileo International (Constantinos et al., 2020).

The network services allows to provide tourists and travel agents with information about travel products and services, ticket reservation process, direct messaging and ordering additional services. More than 80 major hotel chains, such as Radisson, Hilton, Holidays, are connected to the network and allow travel agents to book hotel rooms (Constantinos et al., 2020).

Saber Travel Network is an organization that connects sellers and buyers of travel services through the world's largest trading platform - Saber Global Distribution System (GDS). More than 55,000 travel agencies and more than 400 airlines, 86,000 hotels, 25 car rental companies, 12 cruise companies are connected through Saber, which allows to develop the tourism industry (Constantinos et al., 2020).

Worldspan is an information system that provides reservations mainly for flights (487 airlines), but also in hotels (39 thousand hotels and 216 hotel chains), travel agencies, theaters and other cultural enterprises, car rental companies (rent 45 large companies). Worldspan also provides all the necessary background information related to travel and tourism. Currently, the system is used by more than 25,000 travel agencies around the world (Constantinos et al., 2020).

Table 1. Description of the main global distribution systems

\begin{tabular}{|c|c|c|c|c|}
\hline GDS Name & Amadeus & Galileo & Sabre & Worldspan \\
\hline Founders & $\begin{array}{c}\text { Lufthansa, Air } \\
\text { France, Iberia }\end{array}$ & $\begin{array}{c}\text { British Airways, } \\
\text { Swissair, Alitalia }\end{array}$ & $\begin{array}{c}\text { American } \\
\text { Airlines, IBM }\end{array}$ & $\begin{array}{c}\text { Delta Airlines, } \\
\text { Northwest } \\
\text { Airlines }\end{array}$ \\
\hline Year of foundation & 1987 & 1987 & 1964 & 1991 \\
\hline $\begin{array}{c}\text { Number of } \\
\text { connected airlines }\end{array}$ & 489 & 470 & 420 & 365 \\
\hline $\begin{array}{c}\text { Number of } \\
\text { connected hotels }\end{array}$ & 51794 & 56000 & 40000 & 26000 \\
\hline $\begin{array}{c}\text { Number of car } \\
\text { rental companies }\end{array}$ & 48 & 24 & 50 & 40 \\
\hline $\begin{array}{c}\text { Number of } \\
\text { terminals }\end{array}$ & 100166 & 119400 & 122891 & 47950 \\
\hline
\end{tabular}

Source: created by the author on the basis of (Emmanuel et al, 2018)

Therefore, GDS is a computer web service that provides pricing, real-time services availability, centralized data display with reservation functions for the global travel industry in a single process. Amadeus, Saber, Galileo and Worldspan are the main four providers of GDS in the tourism industry, which help travel agents increase their travel operations. Each of these systems has certain technical features and special conditions of interaction with tourism enterprises. 
Among Ukrainian tourism companies, the most common are such GDS as Amadeus and Saber, as they allow the most efficient use of their opportunities to work in the European and American tourism markets. Table 2 shows a comparison of the terms of usage and integration of both global distribution systems.

Table 2. GDS terms of service comparison

\begin{tabular}{|c|c|c|}
\hline Paragraph & Amadeus & SABRE \\
\hline $\begin{array}{l}\text { Air segments sale rate for free } \\
\text { system usage }\end{array}$ & $\begin{array}{l}75 \text { segments per terminal per } \\
\text { month }\end{array}$ & $\begin{array}{l}30 \text { segments per terminal per } \\
\text { month }\end{array}$ \\
\hline $\begin{array}{c}\text { Service fee for the sale of } \\
\text { Content Rail Ukraine by system }\end{array}$ & $10,44 \mathrm{UAH}$ to the cost & $5 \mathrm{UAH}$ to the cost \\
\hline $\begin{array}{c}\text { Incentive per each flight } \\
\text { segment }\end{array}$ & None & $\begin{array}{c}1.50-2.00 \text { USD per each } \\
\text { segment }\end{array}$ \\
\hline Bonus program for agents & $\begin{array}{c}\text { Equivalent of the points: } \\
5 \text { points per air segment } \\
5 \text { points per train segment } \\
10 \text { points per hotel segment } \\
10 \text { points per car rent segment } \\
10 \text { points per insurance segment } \\
50 \text { UAH certificate } \\
=\text { in average } 165 \text { points }\end{array}$ & $\begin{array}{c}1 \text { segment }=5 \text { points }=5 \mathrm{UAH} \\
10 \text { segments }=50 \mathrm{UAH} \\
\text { certificate } \\
\text { Certificate can be used in the } \\
\text { large retail chains in Ukraine, } \\
\text { such as Rozetka, Novus, etc. }\end{array}$ \\
\hline Support center & $\begin{array}{c}\text { Amadeus Service Hub 24/7 } \\
\text { support }\end{array}$ & $\begin{array}{c}\text { Central SABRE Support 24/7 } \\
\text { free online and call center } \\
\text { support }\end{array}$ \\
\hline
\end{tabular}

Source: created by the authors

Regarding economic component, the Saber system encourages cooperation by earning additional profit in the form of incentives for each air segment sold. GDS is and will remain the most important distribution channel for airlines, hotels and car rental companies. However, the Internet also allows GDS companies, eticket providers and even traditional travel agents to host websites that have access to their connections (APIs) and provide services that were previously offered offline (Fig. 2).

The main advantages of global distribution systems are as follows (Stevenson, 2020):

1. The use of the global distribution system indicates an increase rate in the number of corporate customers and tourists.

2. GDS is very effective method to attract foreign travelers. This is the reason why the use of GDS among travel agents is growing exponentially every year.

3. OTA (online travel agents) have significantly improved the experience and convenience of consumer shopping while traveling and increased pricing transparency.

4. GDSs include business models of a retail travel agencies and OTA.

5. GDS allows travel agents to make their travel services available to consumers around the world, where 
they would not otherwise be able to effectively promote their services through direct marketing efforts.

6. Reservation through GDS is safe and secure option, thus complies with most of the corporate clients needs.

7. Travel agents are able to easily get a global platform for their business with a strong impact on the market.

8. The global distribution system is the basis for finding corporate customers around the world.

9. GDS gives an opportunity to check the actual service availability in real time. Thereby managers can view changes in tariffs and easily change price or make special offers. Agents can instantly review all changes and are able to give customers relevant offers.

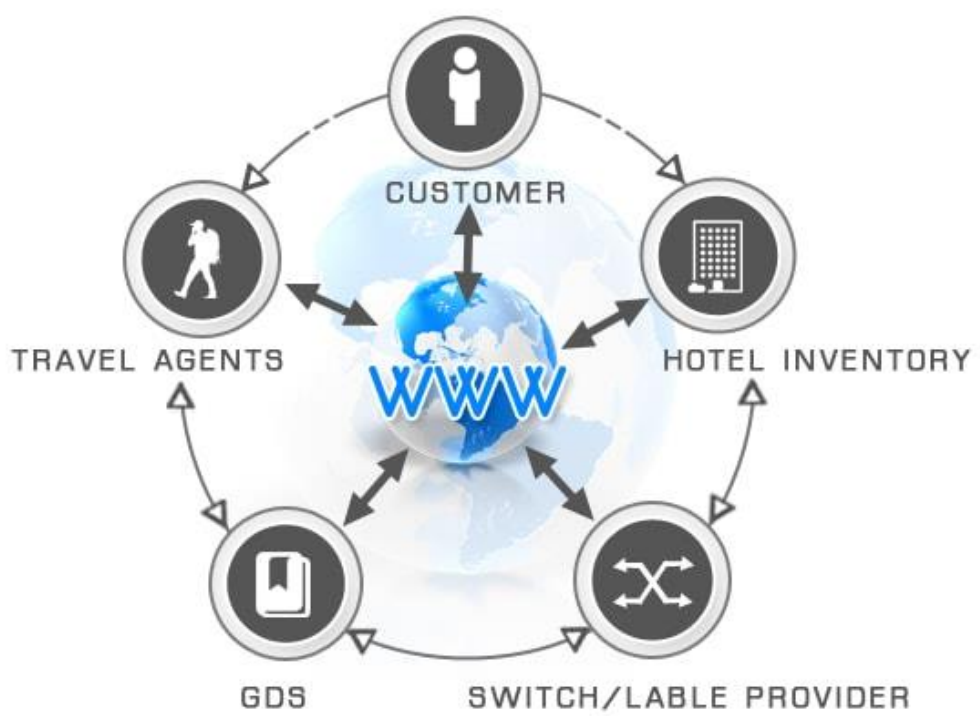

Figure 2. Internet and GDS connection scheme with intermediaries and end customer (GDS, 2021).

Meanwhile, the development of mobile technology and spread of smartphones with 4G and 5G connection support are pushing use of mobile services in the travel business and ensure the interaction of its actors. Currently, mobile websites and applications are able to connect to the API to receive and update data as fast as their desktop versions. For this reason, travel technology providers have focused on developing services to book flights directly from smartphones.

Launched in 2004, the KAYAK iOS app is considered to be the first example of a mobile travel app. Since 2010, mobile websites and applications have become the standard in the travel industry. Soon, all other metasearch travel systems, OTA, airlines reservation tools have created their own mobile applications. Besides, passengers can now use their smartphones as an electronic ticket by scanning the barcode, which became today's standard. 
In 2019, online booking has undergone several minor improvements, which are usually related to overall technical progress. Online payment systems have become much more secure, providing fast processing or even transactions with cryptocurrencies.

The popularization of mobile apps allows travellers to plan a week-long trip in minutes, book tickets, hotel rooms and rent a car in just a few taps. The distribution system is gradually changing every year. An example of recent changes is the New Distribution Capabilities (NDC), which have been in place since 2012. Although it did not bring major changes, it forced GDS to introduce more modern data transmission channels to distribute supplementary products to consumers. In consequence, more online booking platforms and OTA have gained access to rich content, giving customers more opportunities.

\section{CONCLUSION}

The growth of the tourism sector subsequently affects the transport and communications sectors, which due to the growing demand for travel have become one of the main consumers of innovation and information technology, namely: computer reservation systems, global distribution systems, electronic information and communication systems. There was a clear increase in the number of airlines, transport companies, as well as the growth of air traffic. It has led to the creation and implementation of computer reservation systems, which have become the main tool for tickets reservation. Global distribution systems provide an opportunity to significantly improve the quality of customer service by reducing reservation time, refining the quality of service and overall efficiency of airline staff.

In general, the use of information technologies, modern information systems, GDS in particular, allows to ensure interaction of small and large tourism enterprises. Furthermore, it allows:

- customize the experience of clients of travel agencies and travel service providers;

- involve the main providers of tourist services in a reliable and efficient global commercial network;

- use modern management and marketing tools in the activities of tourism enterprises, which allow to increase competitiveness and ensure sustainable development;

- provide an opportunity for airlnes to use information systems in their offices to improve interaction with agents and partners;

- provide global services through unified e-commerce systems in the tourism industry, as well as provide integrative relationships with key players in the tourism business.

\section{Conflict of interests}

The authors declare no conflict of interest. 


\section{References}

Buhalis, D. (2004). eAirlines: Strategic and tactical use of ICTS in the Airline Industry. Information \& Management, 41(7), 805-825.

Chairoel, Lucy \& Widyarto, Setyawan \& Pujani, Vera. (2015). ICT adoption in affecting organizational performance among Indonesian SMEs. The International Technology Management Review. Vol. 5. 82-93. 10.2991/itmr.2015.5.2.3.

Constantinos Halkiopoulos, Hera Antonopoulou, Dimitrios Papadopoulos, Ioanna Giannoukou, \& Evgenia Gkintoni. (2020). Online reservation systems in e-Business: Analyzing decision making in e-Tourism. Journal of Tourism, Heritage \& Services Marketing, 6(1), 9-16. https://doi.org/10.5281/zenodo.3603312

eBusiness W@tch, (2006), ICT and e-Business in the Tourism Industry, Sector Impact Study No. 08 / 2006, European Commission, http://www.ebusiness-watch.org/resources/tourism/SR08-2006_Tourism.pdf

Emmanuel, A.A., Oluwafunmilayo, O.O., Mobolaji, O.A., Abioye, A., \& Adedoyin, O.O. (2018). Perception of Travel Agents Towards Amadeus and Galileo Global Distribution System. Canadian Social Science, 14, 17-30.

Emmer, R.M., Tauck, C., Wilkinson, S., \& Moore, R.G. (1993). Marketing hotels using global distribution systems. Cornell Hotel and Restaurant Administration Quarterly, 34(6), 80-89.

Global Distribution Systems / VIPSERVICE Partners, 2021. URL: https://www.vipservice.ru/En/partners/partners2.php.

Laverty, S. (2014). Impact of technology on the travel agency business, Houston Cronical. http://smallbusiness.chron.com/ impact technology-travel-agency-business-57750.

Lukjanova, L., Odinokova, T. (2020). Innovations as the main challenge in the field of health tourism in Latvia. Access to science, business, innovation in digital economy, ACCESS Press, 1(1): 39-52. DOI: https://doi.org/10.46656/access.2020.1.1(3)

Marinov, M., Todorova, L. (2020). Effects of the COVID - 19 Impact on the Tourism Sector in Bulgaria. Izvestia Journal of the Union of Scientists - Varna. Economic Sciences Series, 9(2), pp.68- 75. DOI: https://doi.org/10.36997/IJUSV$\underline{\mathrm{ESS} / 2020.9 .2 .68}$

O’Connor, P. (1999). Electronic Information Distribution in Tourism \& Hospitality, Wallingford:CAB.

Petrova, M., Dekhtyar, N., Klok, O., \& Loseva, O. (2018). Regional tourism infrastructure development in the state strategies. Problems and Perspectives in Management, volume 16(4), $259-274$. https://doi.org/10.21511/ppm.16(4).2018.22

Porter, M. E. Competitive Strategy: Techniques for Analyzing Industries and Competitors. New York: Free Press, 1980. (Republished with a new introduction, 1998.)

Shkola, I. (2003). Management of tourism industry (662 p.). Chernivtsy: ChTEI KNTEU.

Stevenson (2020). Why is GDS important to the travel industry? URL: https://medium.com/@ stevenson14789632/whyis-gds-important-to-the-travel-industry-551ed4bffc2

Todorova, L. (2018A). Possibilities for Bulgaria's development as a multi-aspect tourist destination. Quantitative and qualitative analysis in economics: Proceedings of the International Scientific Conference - Nis, October 18, 2018, p. 137-142, ISBN: 978-86-6139-170-5

Todorova, L. (2018B). The development of cultural tourism in Bulgaria-a springboard for increasing the attractiveness of the destination. Izvestia Journal of the Union of Scientists - Varna. Economic Sciences Series, 7(1), pp.121-127.

Todorova, L. (2017). Challenges to entrepreneurs in the tourist sector in Velingrad municipality. Proceeding of University of Ruse, 2017, vol. 56, book 5.1., p.31-36

Todorova, L. (2019). The state and opportunities for the development of tourism in the municipalities in the lower Danube river. Proceedings of the International scientific and practical conference "Bulgaria of regions'2019", p.333-339

TRAVELPORT, 2021. URL: https://travelport.ua/.

Varnaliy Z., Pugach, A. (2015). Forming the priority guidelines for providing the state есопотіс seсurity / Економіка $\mathrm{i}$ регіон. - 2015. - № 5. - C. 3-9: http://nbuv.gov.ua/UJRN/econrig_2015_5_3.

Werthner, H., \& Klein, S. (2005). ICT-enabled innovation in travel and tourism. Innovation and product development in tourism (pp.71-84). Berlin: Erich Schmidt Verlag. 
About the authors

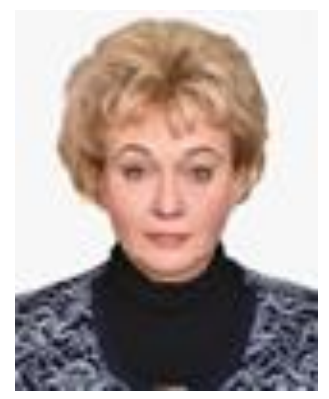

\section{Svitlana LABUNSKA}

Dr.Sc. (Economics), Professor, Simon Kuznets Kharkiv National University of Economics, Kharkiv, Ukraine. Scientific interests: innovation activities cost management in the system of economic security of the enterprise financial and economic activities.

ORCID ID: https://orcid.org/0000-0002-0989-6806

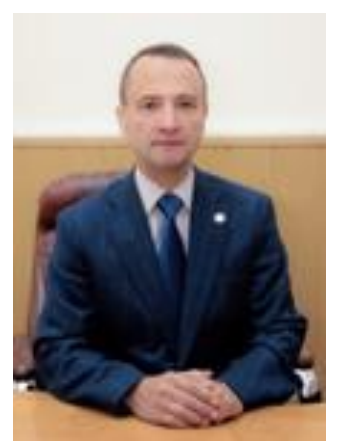

\section{Oleksandr ZYMA}

$\mathrm{PhD}$ (Economics), Associated Professor, Simon Kuznets Kharkiv National University of Economics, Kharkiv, Ukraine. Scientific interests: tourism and hospitality, economics and management, international business.

ORCID ID: https://orcid.org/0000-0001-6917-0858

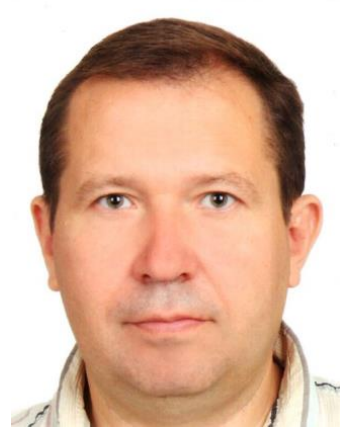

\section{Serhii SUSHCHENKO}

PhD student, Simon Kuznets Kharkiv National University of Economics, Kharkiv, Ukraine. Scientific interests: economics and management, tourism and hospitality.

ORCID ID: https://orcid.org/0000-0003-2990-9683

\section{Copyright (C) 2020 by author(s) and ACCESS Publishing Press This work is licensed under the Creative} Commons Attribution International License (CC BY) 


\title{
DEVELOPMENT OF INNOVATION ACTIVITY RESEARCH MODEL AND ITS IMPLEMENTATION
}

\section{Tatjana Odinokova ${ }^{1 *}, Y_{\text {erbol Akhmedyarov }}^{2}$}

\author{
${ }^{1}$ ISMA University, Riga, Latvia \\ ${ }^{2}$ Sh. Ualikhanov Kokshetau University, Kokshetau, Kazakhstan \\ E-mails: ${ }^{1}$ tatjana.odinokova@isma.lv, 2 ahmediarov_e_a@mail.ru
}

\section{Received:20 December 2021 Accepted:27 December 2021 Online Published:29 January 2022}

\begin{abstract}
The issue of innovation activity in business has been relevant for quite a while now, oftentimes, it is a survival factor for an enterprise. However, it is not only the innovation activity of enterprises that is relevant, but also the research models of such activity. This article deals with innovation activity model and its implementation in practice. We can consider a research model as a program or plan of research. It can be represented both in a diagram based and a descriptive form. It offers the possibility to link theory and empirical data obtained in the course of scientific research, and also enables their subsequent interpretation.

In order to develop a model for innovation activity research in small and medium sized enterprises, analysis of theoretical and empirical methods of scientific research in tourism was carried out. A number of theoretical methods, such as formulation of a hypothesis, assimilation, analysis and others were used as the basis for the model. However, the model is basically built on the empirical method, namely, the method of sociological survey. The model under discussion was tested in 2019 and later applied again in 2020. The number of respondents taking part in the survey were 69 tourism companies (56.9\%) in 2019, and 71 (58.5\%) in 2020. The geography of the use of the research model can also be expanded. In particular, the authors plan to test it in Kazakhstan, which does not fully use the existing high tourist potential.
\end{abstract}

Keywords: research model, innovation activity, small and medium sized enterprises, innovation, tourism.

JEL classification: $A 14 ; 030 ; Z 30$

\section{Citation:}

Odinokova, T., Akhmedyarov, Ye. (2022). Development of innovation activity research model and its implementation. Access to science, business, innovation in digital economy, ACCESS Press, 3(1): 29-42.

https://doi.org/10.46656/access.2022.3.1(3)

\section{INTRODUCTION}

Innovation activity in business is an important factor of effectiveness and competitiveness. Oftentimes, it is a survival factor for an enterprise. Innovation activity is an issue relevant for enterprises having any scale of

\footnotetext{
${ }^{*}$ Corresponding author, Tatjana Odinokova, tatjana.odinokova@isma.lv
} 
production and operating in all kinds of fields. A lot of businesses are looking for innovative ways to improve efficiency and maintain competitive advantage in order to survive (Arsawan et al, 2021; Bogoyavlenska et al, 2020; Jurgelevičius \& Kučaidze, 2020; Lukjanova, Sushchenko, Zima, 2019; Lukjanova, 2019; Petrova \& Akhmedyarov, 2019; Petrova et al, 2018; Sushchenko, 2016).

However, the official Latvian statistics does not keep record of innovation activity in different industries and only lays emphasis on the major sectors of economy, such as production sector, agriculture and services. This approach creates a number of problems. Researchers involved in evaluating innovation activity of enterprises in a certain sector face a lack of specific information. Incidentally, the authors of this article was faced with the necessity to develop a research model while she was involved in analyzing innovation activity of small and medium sized enterprises in Latvian tourism industry.

\section{METHODOLOGY}

A model can be defined as a commonness of interrelated concepts which underlie the research, as well as a systematic description of the area under study. In order to develop a model for innovation activity research in small and medium sized enterprises, analysis of theoretical and empirical methods of scientific research in tourism was carried out. The reason why new and small businesses have become key players in the innovation process has been their ability to identify and exploit business opportunities which emerge as a result of technological, competitive and market developments (Labunska et al, 2017). A number of theoretical methods, such as formulation of a hypothesis, assimilation, analysis and others were used as the basis for the model. However, the model is basically built on the empirical method, namely, the method of sociological survey. The works of V.A.Yadov (2007), N.A.Balyuk (2012), A.V.Borisova (2013), M.J.Baker (2020) and others, were used in the course of method development.

The main reason why this particular research method was chosen was the lack of statistical data concerning innovation activity in small and medium sized enterprises (SMEs) in tourism.

Besides that, this method offers an opportunity:

- for enterprises to carry out self-evaluation;

- to identify the main kinds of innovation in Latvian tourism;

- to define the factors which encourage or discourage innovation activity in SMEs.

The reason why new and small businesses have become key players in the innovation process has been their ability to identify and exploit business opportunities which emerge as a result of technological, competitive and market developments.

\section{STAGES OF DEVELOPMENT OF INNOVATION ACTIVITY RESEARCH MODEL}

The first step in the process of model development is to correlate the object and the subject of research and the context. Considering the area of this research, the factors that encourage innovation activity are the 
context in question. Latvian small and medium sized tourism enterprises are the object, while the subject of this research is innovation activity of small and medium sized enterprises in tourism.

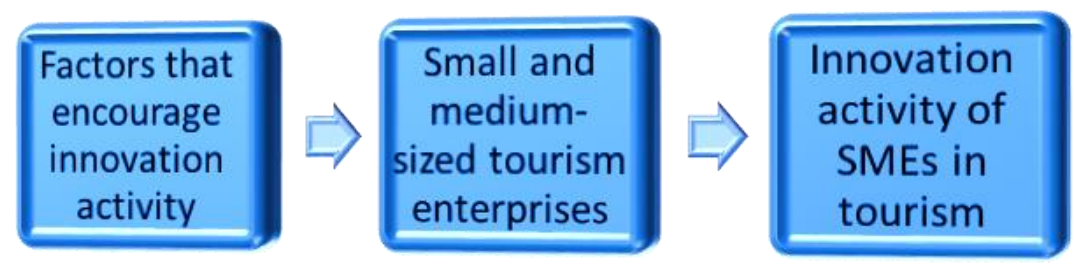

Figure 1. Logical structure of innovation activity model in SMEs in tourism Source: Authors illustration

In accordance with the method suggested by N.A.Balyuk (2012), this research has been divided into the following stages: preliminary stage, field research, data preparation and processing, conclusive stage.

Stage one being preliminary, involves a number of steps. This is actually the development of the research program, i.e. formulation of a hypothesis.

Step one at this stage is to define the problematic situation and the issue itself. The problematic situation amounted to the lack of innovation activity in Latvian SMEs in general, and in the service sector in particular. Based on this problematic situation, we stated the issue of the sociological survey, namely, low innovation activity in Latvian small and medium sized tourism enterprises. The object of this research are small and medium sized tourism enterprises.

The consideration that determined the choice of the object is as follows: Latvian economy is based on SMEs. Moreover, all the tourism enterprises (travel agencies) fall under the category of SMEs. This object was chosen because it was impossible to provide a reliable assessment of the level of innovation activity in MSEs in tourism, and this despite the fact that these enterprises contribute substantially to the national economy.

Step two was to define the aims and objectives of the research with respect to the selected object and subject. The aim of any sociological research is to obtain the expected end result, which will help solve the identified problem. Hence, the aim of this research is the assessment of innovation activity in Latvian SMEs in tourism.

The objectives of a sociological research involve specific requirements to the analysis of and the solution to the issue that has been formulated. That said, the main objectives were stated as follows:

- to define the level of innovation activity in Latvian small and medium sized enterprises in tourism;

- to identify the main causes of insufficient innovation activity;

- to define the main factors which encourage or discourage innovation activity in tourism SMEs;

- to find out main kinds of innovation in small and medium sized tourism enterprises. 
Step three involved clarification and interpretation of the concepts, innovations in tourism and small and medium sized enterprises. In Latvia, this group of enterprises comprises businesses with 10 to 250 employees. The main kinds of innovation in tourism are technological, managerial, marketing and institutional ones.

Step four is formulation of a hypothesis. We studied two main hypotheses, namely:

- low innovation activity in Latvian small and medium sized tourism enterprises.

- insufficient government support of innovation activity in Latvian small and medium sized tourism enterprises.

The first hypothesis has to do with low figures of innovation activity in Latvian SMEs in general and in the service industry in particular. Experts consider innovations as Latvia's Achilles heel. According to the data published by European innovation scoreboard (EIS), Latvia is a Moderate Innovator. Latvia's lowest indicator scores are on $\mathrm{R} \& \mathrm{D}$ expenditures in the business sector, new doctorate graduates, Public-private copublications, and SMEs innovating in-house. Low investment in R\&D, low overall innovation performance and an average educational performance are negatively affecting Latvia's efforts to achieve higher productivity. Latvia is lagging behind the EU's innovative economies in the following fields: capacity of research institutions, spending on $R \& D$, international inventions, patent applications and the like. On the European Innovation Scoreboard 2020, the 2020 edition of a publication published by the European Commission each year, Latvia came 23rd out of 27 EU countries. (European Innovation Scoreboard, 2020) These data reflect the situation in the previous years. Based on this information, we made an assumption that SMEs in tourism also show low innovation activity.

The ground for the second hypothesis is the fact that most of the countries where SME innovation activity index is high, the governments use all kinds of incentives to support innovation.

Both hypotheses are explanatory, because they suggest a cause-effect relationship in the object under study.

Stage two is field research. At this stage we developed the methods for data collection and analysis. We also developed the tools which involved the following steps:

- determining the plan and type of sociological research;

- determining the method of data collection and preparation of the tools;

- determining the system of survey unit selection (of the aggregate under study);

- determining the main procedures of data analysis.

The issue of low innovation activity in Latvian small and medium sized enterprises has not been studied yet, which determined the type of research, namely, reconnaissance research. All the studies have been aimed at a general assessment of innovation activity in Latvian SMEs without respect to specific industries.

The authors deemed it necessary to apply one method of data collection, namely, survey (questioning and interviewing). For the purposes of this investigation, a questionnaire has been worked out. It consisted of three parts - introduction, the body and personal details. 
The respondents of the survey were entrepreneurs looking to increase their revenue and profits by applying innovations. The address to respondents also identified the aim of the survey, namely, to develop suggestions for promoting innovation activity in Latvian small and medium sized enterprises. The guidelines on how to fill in the questionnaire were written next to the questions of the body.

\section{RESULTS and DISCUSSION}

The model under discussion was tested in 2019 and later applied again in 2020. The number of respondents taking part in the survey were 69 tourism companies (56.9\%) in 2019, and $71(58.5 \%)$ in 2020.

The body of the questionnaire is divided into several parts. The aim of part one is to determine the overall evaluation of innovation activity in SMEs in tourism. In fact, travel agents were supposed to carry out selfevaluation. The answers were assessed on a scale from 1 to 5, with 1 being minimum activity, 5 - maximum. Research has shown a slight improvement in evaluation: the percentage of companies which gave themselves 5, 4 or 3 out of five increased. At the same time, the number of respondents that gave themselves 1 for innovation activities decreased.

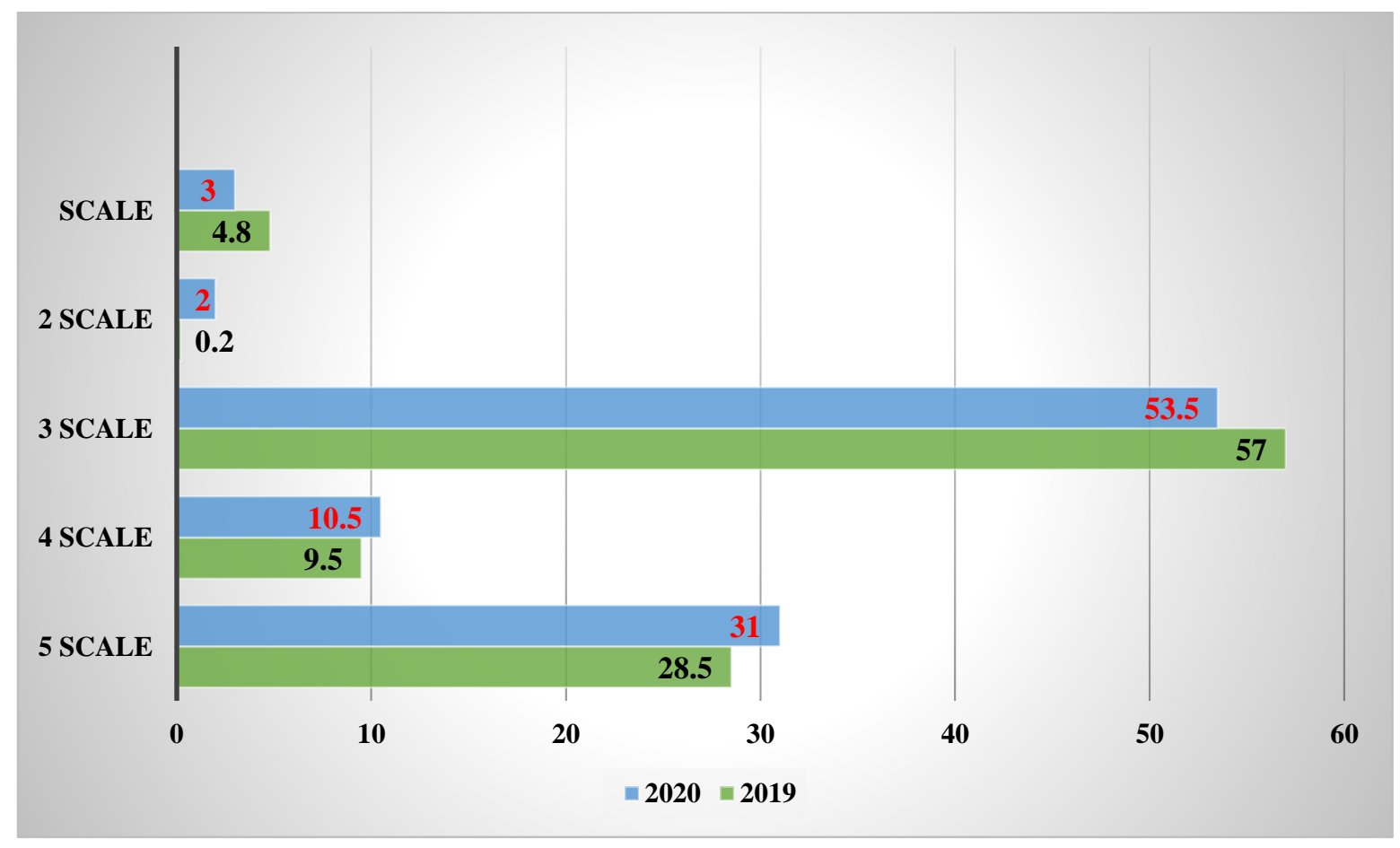

Figure 2. Evaluation of activity in creating new or enhanced products or technologies.

Source: Authors illustration

Besides that, respondents were asked to specify the main types of innovation which had been implemented in the last 3 years. The survey has shown that all kinds of innovation are applied to a greater or lesser degree at all the enterprises under study. All the respondents have marked "Opening new tourism routes, launching a new tourism product". 95\% and 98\% marked "Adding new destinations and new 
markets". $62 \%$ and 63\% "Use new equipment and technologies", "Use new tourism resources" and "Apply new methods of organizing business process management". The findings of this investigation are represented in Fig. 3 in ascending order.

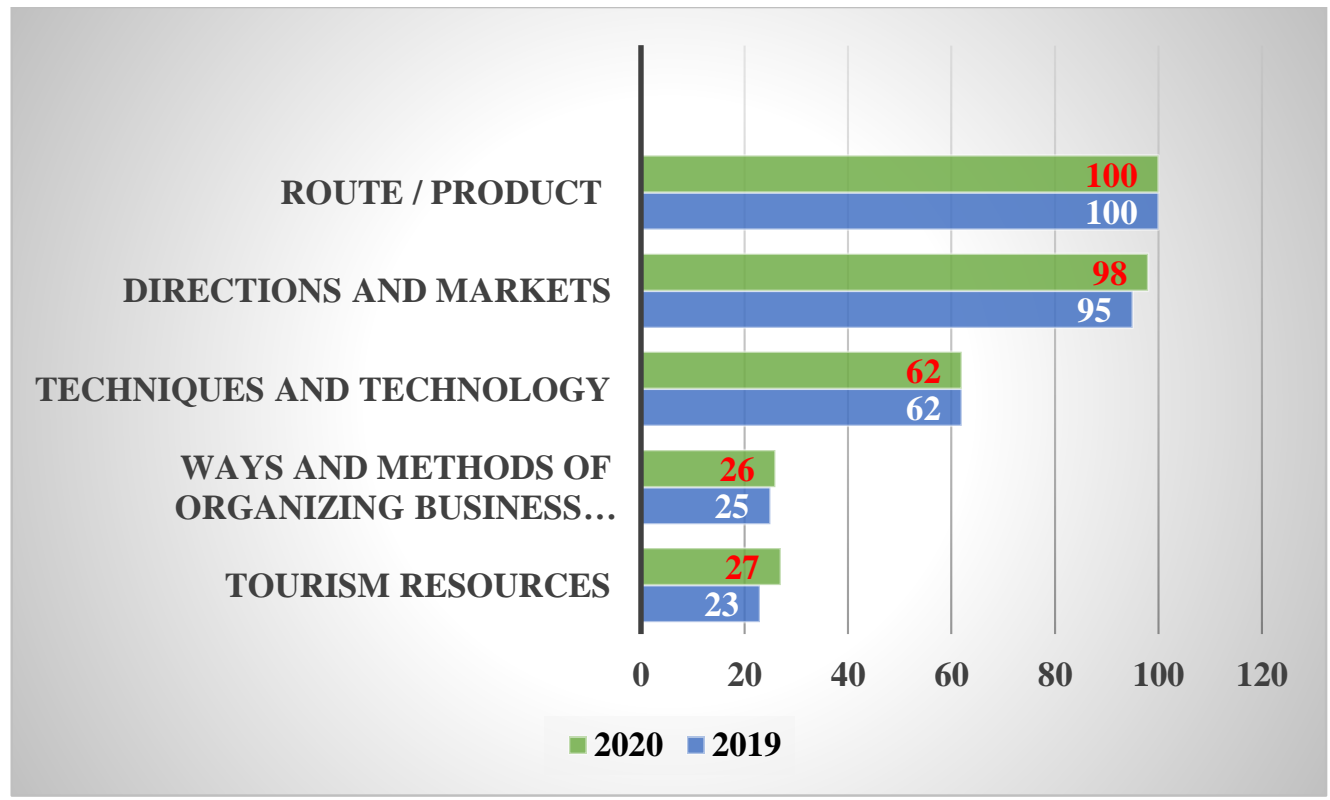

Fig. 3 Main types of innovations in tourism enterprises in the last 3 years.

Source: Authors illustration

In the second part, the respondents were asked to evaluate the significance of the factors that influence their innovation activity in a positive or negative way. "Government policy", "Lack of qualified personnel" and "Lack of investment" were among the causes of insufficient innovation activity. It is to be noted that respondents' opinion has remained practically the same over the past period (Table 1).

Table 1. Main reasons for insufficient innovation activity

\begin{tabular}{|l|c|c|}
\hline Main reasons for insufficient innovation activity & $\mathbf{2 0 1 9}(\boldsymbol{\%})$ & $\mathbf{2 0 2 0}(\boldsymbol{\%})$ \\
\hline Government policy & 61,9 & 63 \\
\hline Lack of qualified personnel & 52,4 & 51,3 \\
\hline Problems related to attracting investments & 42,8 & 44,2 \\
\hline $\begin{array}{l}\text { Lack of complete, reliable and timely information about } \\
\text { the state of the market }\end{array}$ & 23,8 & 25,5 \\
\hline Lack of necessary tourism infrastructure & 23,8 & 22 \\
\hline
\end{tabular}

Source: Own calculations

These figures reveal certain shortcomings in the work of Latvian government structures that are responsible for the state policy in promoting innovation. At present, not even data on the level of innovation 
activity in different industries, and tourism in particular, are available. Assumptions can only be made on the basis of general statistical data. The lack of qualified personnel is another issue to be considered. There are a number of universities and colleges offering a course in tourism, which are involved in a competition to attract and retain students. This aspect needs a separate investigation in order to find out the reasons for low qualification of Latvian graduates in tourism industry.

As many as nearly half of the respondents marked "Problems with attracting investment". However, such reasons as "Weak management/leadership" or "Organizational culture of enterprise" were marked by very few respondents (about 5\%).

Furthermore, the respondents were asked to answer the question: "What is necessary for an active use of innovations in your company?" The majority of the respondents $(80.9 \%)$ chose "qualified personnel"; the second most significant reason was "Tax exemptions for tourism companies" and "Use of up-to-date information and communication technologies" (76\%). "Effective Management" ranked third, which takes us back once again to the issue of personnel qualifications and managerial personnel in particular.

The respondents consider that "Cooperation with clients" and "Cooperation with suppliers" are the most important factors that affect an active use of innovation. Key factors are shown in Table 1.

Table 2. What is necessary for an active use of innovation in your enterprise?

\begin{tabular}{|l|c|c|}
\hline What is needed for an active use of innovations & $\mathbf{2 0 1 9}(\boldsymbol{\%})$ & $\mathbf{2 0 2 0}(\boldsymbol{\%})$ \\
\hline Qualified personnel & 80,9 & 80 \\
\hline Use of up to date technologies, such as social networks & 76 & 79 \\
\hline Fiscal incentives & 76 & 77 \\
\hline Effective management & 71,4 & 73 \\
\hline Cooperation with suppliers & 61,9 & 61,9 \\
\hline Cooperation with clients & 61,9 & 71,5 \\
\hline Financial support from the government & 57 & 59,2 \\
\hline Creative environment & 57 & 57 \\
\hline
\end{tabular}

Source: Own calculations

When asked about their plans in so far as the development of innovation activity is concerned, over $90 \%$ of the respondents are planning "To develop along the same lines".

Question 6 asked the respondents to choose which of the four statements best describes their commitment to embrace innovation.

Most of the respondents (38\% each) have chosen "Innovation is among our priorities. We are able to generate new ideas and approaches" and "We value innovation. We are able to recognize new ideas and approaches and to implement them quickly". 19\% answered that "Innovation is our primary objective. We are creative and implement new ideas and approaches regularly". Only $4.8 \%$ answered that "Innovation is 
not a priority in the markets where we are working". The responses that we have analyzed have shown that the majority of the respondents are willing to use innovation and consider it as a priority.

Part three of the research contained a number of questions related to the number of employees, types of tourism as well as the location of the enterprise. The answer to the question "Number of employees" helped to eliminate bigger enterprises which employed over 250 people, while processing data. The respondents' answers to this question have shown that over the past period, there has not been any significant change, and micro enterprises still account for over $60 \%$.

When asked about "Area of travel agent's operation" the majority of the respondents $(50.0 \%)$ are only involved in incoming tourism, and nearly $5 \%$ in only outgoing tourism. However, about $43 \%$ operate in both areas.

Another aspect investigated in this research was to determine the types of tourism offered by Latvian travel agents. The results are shown in Table 3. We can see that cultural tourism ranks first (95.2\%), event tourism being second $(57.1 \%)$. The fewest number of the respondents operate in the area of religious and pilgrimage tourism (28.6\%), and in agricultural tourism (23.8\%). Despite the viability of business tourism, only $42.9 \%$ of the respondents operate in this area.

Answers about the location of tourism enterprises have shown that over $90 \%$ of the companies involved in the survey are situated in Riga or Riga district, and the rest are located in Liepaja, Daugavpils and Ventspils.

The next step at stage two of model development was to define the types of questions. For the purposes of this survey, closed or semi-closed questions have been used. Closed questions are meant to contain several options for the answers which are to be worked out before the survey begins.

Table 3. Types of tourism offered by your enterprise

\begin{tabular}{|l|c|c|}
\hline Kinds of tourism & $\mathbf{2 0 1 9}(\boldsymbol{\%})$ & $\mathbf{2 0 2 0}(\boldsymbol{\%})$ \\
\hline Cultural & 95,2 & 94,6 \\
\hline Health and wellness & 47,6 & 49,0 \\
\hline Business & 42,9 & 43,2 \\
\hline Rural & 23,8 & 25,2 \\
\hline Event based & 57,2 & 54,3 \\
\hline Gastronomic & 52,4 & 52,4 \\
\hline Sports & 38 & 36 \\
\hline Religious and pilgrimage & 28,6 & 29,6 \\
\hline Educational & 33,3 & 34,5 \\
\hline Other & 4,8 & \\
\hline
\end{tabular}


For example, "Name the main types of innovation in your enterprise over the last 3 years", "Which sector of tourism does your enterprise operate in?" Closed questions have a number of advantages, because they are easy to process and are not time consuming for the respondent when they are completing a questionnaire. Our survey has proved this point, since all our respondents took a short time answering this particular group of questions.

However, where it was not possible to exhaust all conceivable answers, semi-closed questions were used. With this type of question, the respondent could use one of the answers suggested in the questionnaire or come up with their own answer. The last item on the list of semi-open questions was "Other", e.g. "other factors of insufficient innovation activity in your enterprise". Semi-closed questions offer the respondent an opportunity to express their opinion about certain questions. It should be noted however, that quite a few respondents marked these options but were reluctant to elaborate. It is highly likely that most respondents were reluctant to spend their time thinking over and writing their answer.

It is to be noted that the questionnaire also contained a number of answer options with peculiar design specifics, namely, scale questions and multivariate ones. When answering a scale question, a respondent is supposed to specify the intensity of the matter in question. As an example, they may be asked to evaluate innovation activity in their enterprise. With multivariate questions, however, respondents are asked to choose one of the answers on the list.

Since the respondents were supposed to give their personal opinion about innovation activity, which basically meant that they had to make self-evaluation, direct questions were used in the questionnaire. On the other hand, when the questions were connected with the factors that encourage or discourage innovation activity, it was the opinion of the executives of Latvian tourism SMEs that was relevant. The use of indirect questions meant consent or lack of consent with other's opinion.

The use of procedural (functional) questions helped to enhance the course of sociological survey. Procedural questions concerned:

- location of the enterprise;

- number of employees;

- types of tourism.

Filter questions helped to single out a group of respondents according to a definite characteristic, such as the level of competence, for example. A filter question was used when the respondents were asked to mark the main types of innovation in a tourism enterprise.

In the course of a sociological research, it is not possible to investigate all the elements of the object under study. Therefore, it is necessary to create an aggregate to be investigated. It is necessary to separate the elements which are to be studied. For example, of all Latvian tourism companies, only small and medium sized enterprises were singled out. However, statistical data led us to a conclusion that all Latvian tourism operators are in fact SMEs. Therefore, selection method has been applied. This is a formalized method which is built according to pre-defined rules. Selection method helps to achieve maximum 
representation. The main criterion for the choice of a tourism enterprise was its position on the Latvian tourism market. This means that this research was aimed at the leading tourism operators of Latvia.

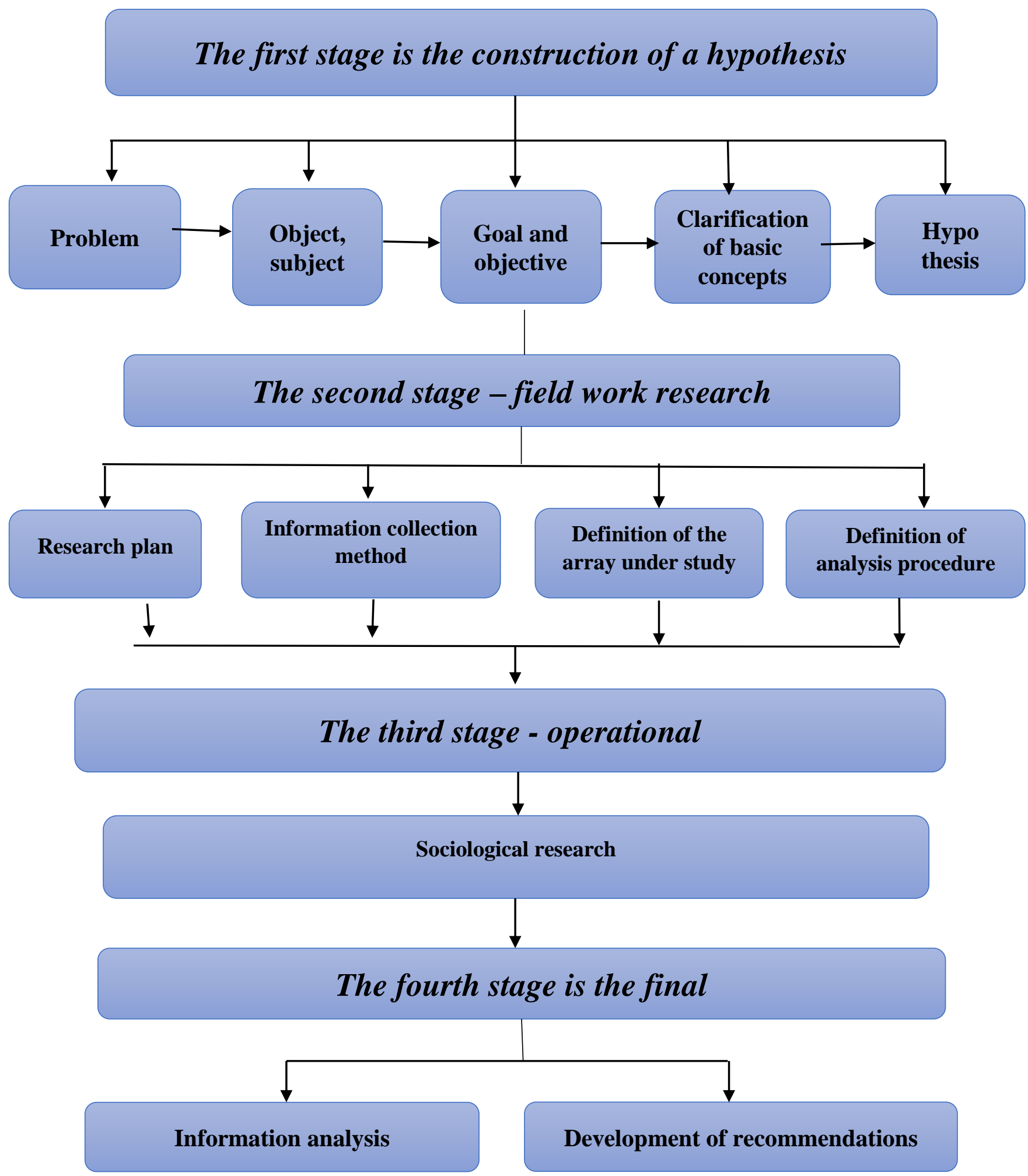

Figure 4. Research model of innovation activity in small and medium sized enterprises in tourism. 
As far as contacts with the respondents are concerned, the author used in-person interviewing. Among the advantages of this kind of questioning is low risk of getting unfilled questionnaires. Besides, the collection of information has a precise timeframe.

The survey that has been carried out can be defined as an expert survey. An expert survey is a specific type of survey. It is not a large-scale survey, but it plays an important part in sociological research. This method is essentially based on data collection from competent persons who have a deeper knowledge about the subject under study. In this case the executives and top managers of tourism enterprises were the experts to be interviewed.

Stage three is operational and procedural. It involved data collection on the object under investigation. In fact, stage three is sociological research itself.

At this stage preliminary data processing was carried out in order to study all the materials that had been collected. Furthermore, the amount of the materials (questionnaires) collected was compared with the preplanned amount of the selected aggregate. Considering a relatively small number of Latvian tourism enterprises, data retrieval was done manually. After that data were analyzed statistically and divided into groups in order to draw up tables and diagrams to provide visual presentation of the data obtained in the course of investigation.

Stage four is the conclusive stage. It involved data analysis and preparation of the resulting documents. The analysis of the collected data helped

1) to assess the level of innovation activity in small and medium sized enterprises in Latvia and prove the first hypothesis;

2) to determine the main reasons for low innovation activity in Latvian tourism SMEs.

3) To provide a better visual presentation, the research model is shown in Figure 4.

In order to determine the final total, the findings of this research have been compared with the official statistical data relating to innovation activity in Latvian SMEs

According to the data published by the European innovation scoreboard (EIS) in 2019, R\&D expenditure in the public sector reached 55.2\%, SMEs product/process innovations - 42.7\%, SMEs marketing/organizational innovations - 43.0\%, and SMEs innovating in-house $-33.9 \%$. (European Innovation Scoreboard, 2020). These figures prove that tourism enterprises perform better in some aspects than Latvia's average. For example, SMEs in tourism are more active in creating new products and the use of marketing innovations.

Based on the information obtained in the course of this research, a number of methods of direct and indirect promotion of innovation activity in Latvian SMEs have been proposed. 


\section{CONCLUSION}

Research model was developed to investigate innovation activity in Latvian tourism SMEs and was first tested in 2019. It was later used in 2020. The application of this model has shown that it needs enhancement and certain amendments, namely:

- Considering extensive use of information technologies and also the restrictions due to COVID19, it is necessary to stop using in-person interviewing as the only option.

- Develop a questionnaire with fewer semi-closed questions in order to reduce the time needed to fill it in.

- To think over the steps aimed at encouraging the management of tourism enterprises to take part in this kind of research.

The fact that Latvian tourism has suffered great losses as a result of COVID 19, does not mean that this industry will not be able to come alive again. As an example, Balttur - the exhibition that has been held in Riga every year, is scheduled to take place in April 2022. This is a demonstration of optimism that exists in tourism industry. It should be noted, however, that the issue of innovation activity has been downgraded on the list of priorities, because tourism enterprises are now using other forms of retaining their business in order to survive. Nevertheless, any epidemic is bound to end sooner or later. It means that Latvian enterprises should start thinking today about boosting their innovation activity.

Moreover, this model with certain modification of the questions can be applied to investigate SMEs not only in tourism but in other industries as well, since the issue of innovation activity in Latvian SMEs is still relevant. Latvia has been in the group of Moderate innovators for a long time now. The geography of the use of the research model can also be expanded. In particular, the authors plan to test it in Kazakhstan, which does not fully use the existing high tourist potential.

In order to make a breakthrough in the area of innovation, it is necessary to change the attitude to innovation activity among entrepreneurs and the public in general. Innovations are indispensable for the growth of prosperity. Therefore, they have to gain extra incentives.

Author Contributions: Conceptualization, T.O.; methodology, T.O.; formal analysis, T.O., Y.A; investigation, T.O.; project administration, T.O.; data curation, T.O; resources, T.O., Y.A.; supervision, T.O.; validation, T.O., Y.A; writing—original draft preparation, Y.O; writing—review and editing, T.O., Y.A. All authors have read and agreed to the published version of the manuscript.

Institutional Review Board Statement: The study was conducted according to the guidelines of the Declaration of Helsinki and approved by the ethics committee of the ISMA University, approval number: $127,8 / 01 / 2019$. 
Informed Consent Statement: Informed consent was obtained from all the participants involved in the study.

Data Availability Statement: The data presented in this study are available on request from the corresponding author. The data are not publicly available due to privacy issues.

\section{Conflict of interests}

The authors declare no conflict of interest.

\section{References}

Arsawan, I. W. E.; Supartha, I. W. G.; Rustiarini, N. W.; Sita Laksmi, P. A. (2021). SMEs Resiliencies and Agility During Pandemic Covid-19: A Bibliography Analysis and Future Directions. Economics. Ecology. Socium, 5, 1928.

Baker M.J. (2020) Selecting a Research Methodology//The Marketing review, vol.1, №3, pp. 373-397.

Balyuk N.A. (2012) Methods of scientific research in service and tourism: tutorial. Tyumen: Publishing House of Tyumen State University.// Metody nauchnyh issledovanij v servise i turizme: uchebnoe posobie. Tyumen': Izdatel'stvo Tyumenskogo gosudarstvennogo universiteta.

Bogoyavlenska, Y.; Persia, L.; Bondarenko, K. (2020). Smart-Logistics for People Management of Innovative Small and Medium Enterprises`Development: Agile Methodology. Economics. Ecology. Socium, 4, 8-15.

Borisova A.V., (2013) Methods of scientific research in tourism: text of lectures. P.G. Demidov Yaroslavl State University.-Yaroslavl: YarSU, 68 p.// Borisova A.V. (2013) Metody nauchnyh issledovanij v turizme: tekst lekcij. YArosl. gos. un-t im. P. G.Demidova.-YAroslavl': YArGU. - 68 s.

European $\quad$ Innovation $\quad$ Scoreboard 2020

(2020). https://ec.europa.eu/commission/presscorner/detail/en/QANDA_20_1150 (accessed: December 2021)

Kuchko E. (2008) The Methods of the Sociological Study of Innovations: Specifics. Potential and the Perspectives of Application // Kuchko E.E. (2008) Metody sociologicheskogo izucheniya novovvedenij. https://elib.bsu.by/handle/123456789/8633 (accessed: January 2019)

Jurgelevičius, A.; Kučaidze, N. (2020). The Development of Innovative Startups and Tech Based Companies in European Countries. Economics. Ecology. Socium, 4, 1-7

Labunska Sv., Petrova M., Prokopishyna O. (2017). Asset and cost management for innovation activity, "Economic Annals - XXI", Volume 165, Issue 5-6, Pages: 13-18.

Latvijas tūrisma attīstības pamatnostādnes 2014.-2020.gadam - https://www.em.gov.lv/lv/nozares_politika/ turisms/ dokumenti/politikas_planosanas_dokumenti/

Latvijas Investīciju un attīstības aǵentūra (2018). Kā attīstīt tūrismu Latvijā? Tūrisma mārketinga stratēǵija 2018. 2023.

Retrieved

from: http://www.liaa.gov.lv/files/liaa/content/Turisms/Prezentacijas/turisma_marketinga_strategija_kopsavilkums.pdf (27.01.2020)

LR Ministru kabinets (2015). Par Eiropas Savienības struktūrfondu un Kohēzijas fonda 2014.-2020.gada plānošanas perioda darbības programmu "Izaugsme un nodarbinātîba". Ministru kabineta rīkojums Nr.62 Retrieved from: https://www.vestnesis.lv/op/2015/26.1? search=on

Lukjanova, J., Sushchenko, O., Zima, O. (2019). Educated and competent staff as important factor of innovation development of machine-building and metalworking industry in Latvia, Sheregesh, X International Scientific and Practical Conference "Innovations in Mechanical Engineering" (ISPCIME-2019). MATEC Web of Conferences, EDP Sciences, vol.297 (06006), 2019, DOI: https://doi.org/10.1051/matecconf/201929706006

Lukjanova, J. (2019). Problems and Trends of Regional Tourism Development in Latvia. Economics. Ecology. Socium. Volume 3, p.1-11. Institute of Market Problems and Economic-and-Ecological Research of the National 
Academy of Sciences of Ukraine, Odessa, Ukraine. ISSN-L: 2616-7107

Petrova, M., Akhmedyarov, $\quad$ Y.. (2019) Foreign experience in supporting innovation. «Economic series of Herald of the L.N. Gumilyov ENU», Issue 4. Publishing: L.N. Gumilyov ENU, Nur-Sultan, Kazakhstan / ISSN (Print) 2079-620X, ISSN (Online) 2617-5193, 2019(4), pp.123-132, DOI: https://doi.org/10.32523/2079-620X-2019-4-123-132/http://bulecon.enu.kz/pages/bulecon4(2019)

Petrova, M., Dekhtyar, N., Klok, O., \& Loseva, O. (2018). Regional tourism infrastructure development in the state strategies. Problems and Perspectives in Management, volume 16(4), $259-274$. https://doi.org/10.21511/ppm.16(4).2018.22

Sushchenko, O. (2016). Creation of innovation clusters as a line of enterprise competitiveness improvement in the field of foreign economic activity, Actual Problems of Economics, 177(3), 191-198

Yadov V. A. (2007) Strategy of sociological research., 194 p.// Yadov V. A. (2007) Strategiya sociologicheskogo issledovaniya. M., S. 194.

\section{About the authors}

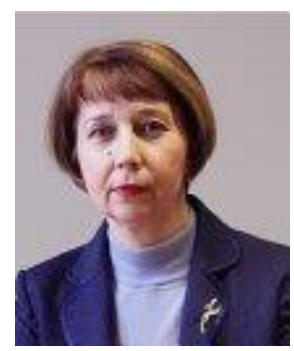

\section{Tatyana ODINOKOVA}

PhD of Economics, Associate Professor, Department of Economics, ISMA University, Riga, Latvia.

Research interests: innovation, innovation activity, start-up, small and medium enterprises, economic growth.

ORCID ID: https://orcid.org/0000-0002-9310-3214

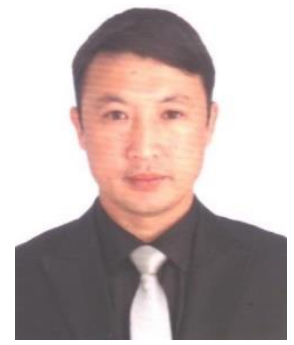

\section{Yerbol AKHMEDYAROV}

Master of Economics, Senior Lecturer, Department of Business and Services,

Sh. Ualikhanov Kokshetau University, Kokshetau, Kazakhstan.

PhD student, L.N. Gumilyov Eurasian National University, Nur-Sultan, Kazakhstan

Research interests: innovation, innovation activity, digitalization of economy, competency model.

ORCID ID: https://orcid.org/0000-0003-0117-8700

Copyright (C) 2020 by author(s) and ACCESS Publishing Press This work is licensed under the Creative Commons Attribution International License (CC BY) 


\title{
TRANSFORMATION OF GEORGIA'S TRADE POLICY STRATEGY: FROM FRAILTY TO SUSTAINABILITY
}

\author{
Giga Abuseridze ${ }^{1}$, Mariana Petrova ${ }^{2,3}$, Vitolds Zahars $^{4}$, Vladas Tumalavičius ${ }^{5}$ \\ ${ }^{1}$ Riga Stradins University, Riga, Latvia \\ ${ }^{2}$ St. Cyril and St. Methodius University of Veliko Tarnovo, Veliko Tarnovo, Bulgaria \\ ${ }^{3}$ ISMA University, Riga, Latvia \\ ${ }^{4}$ Daugavpils University, Daugavpils, Latvia \\ ${ }^{5}$ General Jonas Žemaitis Military Academy of Lithuania, Vilnius, Lithuania
}

e-mails: ${ }^{1}$ giga.abuseridze@ @rsu.lv, ${ }^{2,3}$ m.petrova@ts.uni-vt.bg, ${ }^{4}$ vitolds.zahars@inbox.lv, ${ }^{5}$ vladas.tumalavicius@lka.lt

Received:20 December 2021 Accepted:29 December 2021 Online Published:30 January 2022

\begin{abstract}
The following article reviews the trade policies and practices of Georgia as well as Georgia-WTO relationship. The authors focus on Georgia's recent economic performance, including Association Agreement (AA) with the European Union that contributed powerfully to stabilising Georgia's trade legislation and reinforcing domestic economic reform. The Association Agreement between Georgia and the European Union and its member States aims at Georgia's gradual economic integration into the EU Internal Market, through the establishment of the DCFTA, which should provide for far-reaching market access based on sustained and regulatory approximation.

The study reveals the importance of the World Trade Organization, main trade agreements and arrangements with Georgia as a developing country. It demonstrates that effective trade stabilization in the WTO can be achieved by the implementation of specific WTO's regulations on trade, economic and legal spheres.

One of the reasons for the special success of the WTO is systemic exceptions for developed countries and states with special needs (country like Georgia) that contributes to the development of international trade through progressive liberalization and the comparative advantage of the states when carrying out trade.

The example of Georgia shows very well that so far the country has not been able to actively apply all the advantages that can be used within the framework of international or regional organizations, at least for the simple reason that the country does not possess the appropriate infrastructure for bringing innovative products to foreign markets, and thus accumulate more economic wealth.

This case study evidences and confirms that while the accession process to the WTO is challenging per se, it is part of a process of domestic reforms that triggers growth and economic benefits.
\end{abstract}

Keywords: Association Agreement, European Union, Deep and Comprehensive Free Trade Agreement, Foreign Direct Investment, World Trade Organization

JEL classification: F13, F02, K33

Citation:

Abuseridze, G., Petrova, M., Zahars, V., Tumalavičius, V. (2022). Transformation of Georgia’s trade policy strategy: from frailty to sustainability. Access to science, business, innovation in digital economy, ACCESS Press, 3(1): 43-52. https://doi.org/10.46656/access.2022.3.1(4) 


\section{INTRODUCTION}

Trade diplomacy is a prominent issue in almost every country's foreign relations. Georgia, as a part of the civilized world, despite the challenges, is involved in the process of economic transformation. Georgia has made sweeping economic reforms during the last years, developing from a nearly failed state in 2003 to a relatively well-functioning market economy in 2019. Georgia has achieved significant results in terms of curbing low-level corruption, streamlining an inefficient administration, eliminating unnecessary licensing requirements, improving the State's tax collection capabilities, liberalizing its trade regime and generally improving Georgia's attractiveness based on ease of doing business. However, progress has been coupled with shortcomings, particularly in the aftermath of the 2008 financial crisis and the war with the Russian Federation.

At the same time, it is notable that following parliamentary and presidential elections in 2012 and 2013 respectively, a peaceful transfer of power took place for the first time in Georgia's modern history. Since 2012, the Government has broadly continued the previous Government's low-regulation, low-tax free market policies while modestly increasing social spending. Also, the Russian Federation lifted its embargo on Georgian wine, mineral water and certain agricultural goods in 2013 that had been in place since 2006. The Russian embargo made it clear that modern challenges in Georgia's trade relations required greater diversification in order to avoid and prevent potential threats in the future. Following the signing of the Deep and Comprehensive Free Trade Agreement (DCFTA) with the European Union, the export of Georgian products and their competitiveness in the world market became particularly important (Abuseridze, 2020).

Given this context, the article raises several questions on economic transformation of Georgia. What are the benefits of Georgia's WTO membership for the EU and Georgian businesses?

In order to answer these and many similar questions the authors will analyze Georgia's main trade agreements arrangements and other important issues.

\section{Main trade Agreements and Arrangements}

Trade liberalization is one of the key objectives on Georgia's economic policy agenda. After Georgia's integration into the WTO, country undertook a large number of reform initiatives targeted at streamlining, liberalization and simplification of trade regulations and their implementation. Following the Rose Revolution in 2003, the Georgian government increased efforts to reduce corruption in public and private sector and sought to meet international standards. These efforts resulted in significant improvements in Georgia's ranking in the World Bank's Doing Business Survey. Between 2006 and 2019, Georgia jumped from $112^{\text {th }}$ place in the overall rankings for ease of doing business to the 6th (World bank, 2019).

One of the strategic initiatives is to develop Georgia's trade-transit function. The framework has been established that is intended to allow investors to conduct processing activities in Georgia in connection with the transit of goods without being subject to Georgian taxes (Georgian National Investment Agency, 2021).

As regards main trade agreements and arrangements - after gaining independence in 1991, Georgia's economy collapsed and it is the only country in the South Caucasus and Central Asia that has not reached its 
pre-independence real GDP level; as of 2013, Georgia's GDP was estimated to be $80 \%$ of its 1990 levels (World Bank, 2014). Georgia's trade policy review in 2009 showed how since the Rose Revolution in 2003, the Government established a structural reform programme that aimed, inter alia, to liberalize trade, improve infrastructure, upgrade the business environment, strengthen public finances and combat corruption. As a result, growth accelerated to an average rate of 9.4\% during 2004-2007. This acceleration was halted by the twin shocks in 2008: the conflict with the Russian Federation and the global financial crisis. The impact of the crises was relatively short-lived and the economy rebounded in 2010-2013, with growth averaging 5.8\%. Over the past decade or so, GDP per capita increased from US\$ 920 in 2003 to US\$3,680.8 in 2014, although Georgia's overall impressive growth performance was not matched by commensurate declines in unemployment and poverty.

At the start of the review period (2009 to 2020), average annual real GDP growth rebounded from $-3.7 \%$ in 2009 to an average of $5.8 \%$ in 2010-2013. GDP per capita increased by over half to reach US\$3,681 in 2014, although Georgia's overall impressive growth performance was not matched by commensurate declines in unemployment and poverty. While the current account deficit has narrowed from a peak of $22 \%$ of GDP in 2008 , it has remained significant at 10-13\% of GDP during 2010-12. Real GDP growth slowed significantly to $3.3 \%$ in 2013 from $6.4 \%$ in 2012, reflecting slower global growth, weak domestic demand and economic deceleration related to the political transition that prompted investor caution. Growth for 2014 recovered to $4.8 \%$ (just below the Government's 5\% target) but the depressed economies of Georgia's major trading partners are expected to halve growth to around 2\% in 2015 (International Monetary Fund, 2018) . The positive dynamics of growth continued for the next 5 years (2015-2020) but due to the COVID-19 pandemic Georgia's GDP Declined by $5.8 \%$ in first half of 2020 .

The key event of this review period occurred in June 2014, when Georgia signed the Association Agreement (AA) with the European Union. The AA includes a Deep and Comprehensive Free Trade Area (DCFTA), which plans to enhance Georgia's trade prospects and boost economic growth by bringing its legislation closer to that of the EU. It also removes the existing barriers on the trade of goods and services with the EU. Georgian products have to meet certain EU requirements not only for export, but also when consumed within the country.

The authors explain that this study does not aim to explore the hierarchy of legal norms proceeding on the relations between the WTO and EU or their interdependence; rather it focuses on the entries in the Association Agreement between Georgia and the European Union which refer to Georgia's compliance with the WTO obligations and their superior power.

In accordance with Article 1 of the Association Agreement, the goal is to achieve gradual economic integration of Georgia into the EU internal market that will ensure reliable market access based on sustainable and comprehensive regulatory convergence of rights and obligations arising from WTO membership. The signing of the Association Agreement with the EU sends a very positive message to the markets, and helps to promote exports to the area from 2014-2019 (Trade/economic structure and trends see below Figure 1.) onwards, which creates a practical framework for achieving EU-Georgia political association and trade 
integration. Moreover, the authors believe that the tools such as the DCFTA offer the EU an opportunity to spread its sphere of influence to its east, including the Caucasus region. This remains a sensitive area for Europe as it presently depends on Russia to meet its energy needs. Deeply cognizant of this, Russia uses its energy resources as a political bargaining chip. Indeed, as the South Caucasus region belongs to the energyrich Caspian region, it is advantageous in the long-term for Europe to diversify its energy resources and energy partners. The authors argue, that this perspective adds extra stimulus to the development of Georgia into a trade transit corridor.
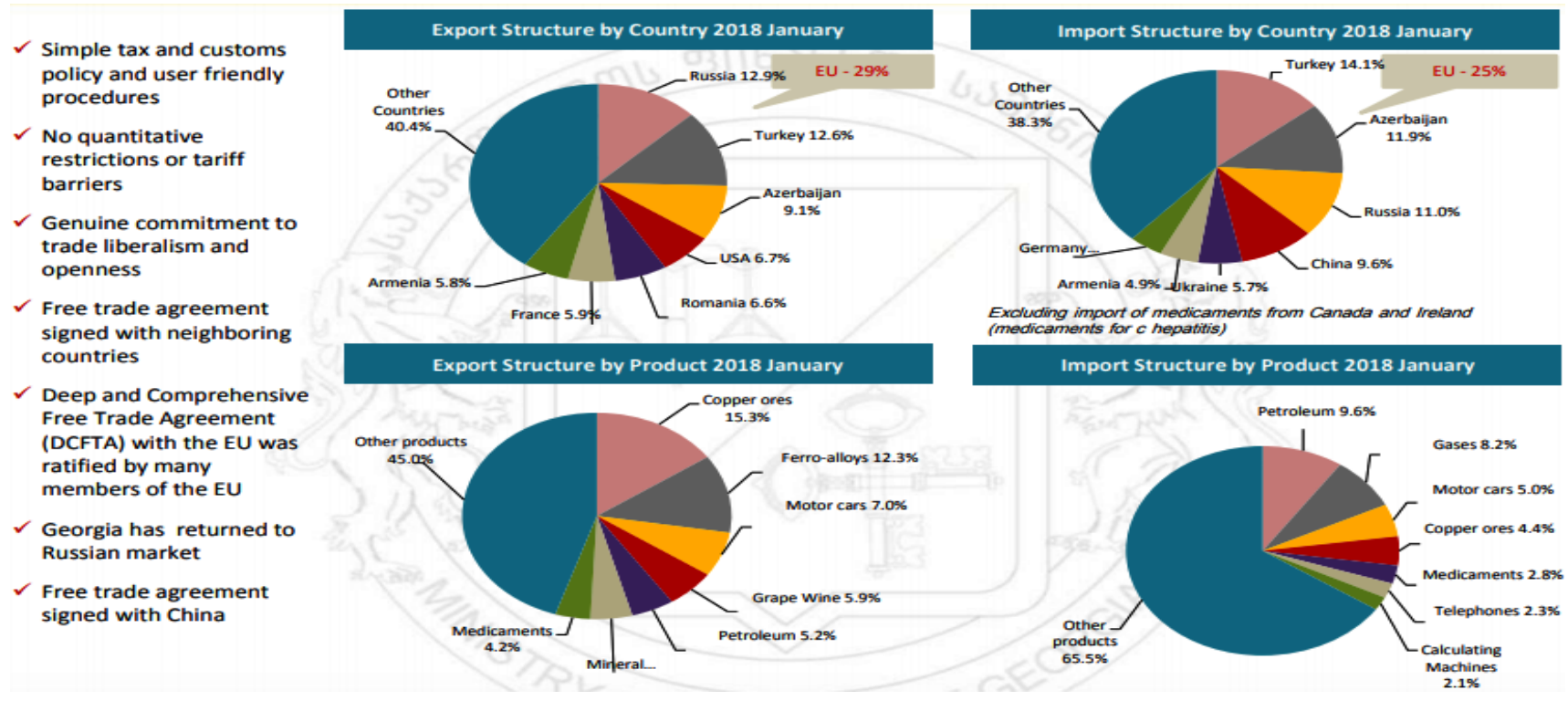

Figure 1. Trade/Economic Structure and Trends*

* Liberalized trade, diverse partners, significant and growing network of free trade agreements.

Source: Ministry of Finance of Georgia (2018). Georgia - The outlook.

National Statistics Office of Georgia online information; IMF, International Financial Statistics online information.

As a member of the WTO since 2000, Georgia grants MFN treatment to all WTO Members. Georgia is an observer to the Government Procurement Agreement. Georgia has GSP arrangements with the United States (temporarily terminated), Japan, Canada, Switzerland and Norway. In 2009, Georgia terminated its membership of the CIS organization but has maintained bilateral FTAs with eight CIS countries and also has an FTA with Turkey, a Trade and Investment Framework Agreement with the United States. Georgia and China are completing a joint feasibility study on a possible Georgia-China Free Trade Agreement and have also signed a Memorandum of Understanding on strengthening cooperation for the Silk Road Economic Belt initiative.

The Ministry of Economy and Sustainable Development is the executive authority which determines, implements and coordinates state policy in the field of trade. In the ministry, the Department for Foreign Trade and International Economic Relations is exclusively involved in the formulation of foreign trade policy. As part of its daily functions, the department closely cooperates with several trade-related bodies under the 
ministry and collaborates with other relevant entities, including in the private sector. The Department implements the mandatory notification submission procedures to the WTO. The main instrument regulating foreign trade in Georgia is the revised 2011 Tax Code of Georgia, which defines objects subject to import taxation, customs regimes and procedures as well the exemption of certain goods from import duties. Legislative amendments have taken place in several trade-related areas. Georgia has continued to develop its national quality infrastructure in accordance with international and EU practices. Its TBT strategy stipulates that Georgia refrains from adopting national standards in the areas where relevant international standards exist. About $98 \%$ of all standards adopted in Georgia are international or European standards (World Trade Organization, 1999).

\section{Georgia's Accession Process and the Implementation of its Commitment}

The process of obtaining Membership of the WTO is complex and implies many challenges for the countries wanting to join and hence the long average duration. Once that goal is achieved, the practice shows that WTO membership creates significant new opportunities. This perhaps best explains why, since the WTO was created in 1995, a total of some 36 countries have taken the initiative to join the WTO and successfully completed the accession process nearly two dozen more are presently negotiating their accession.

Georgia was one of the countries that shortly after becoming an independent state launched the process of joining the WTO in July 1996. This decision was largely driven by the new trade opportunities that WTO membership offers and the decision taken to undertake the necessary reforms with a view of aligning domestic policies with international standards and requirements. Following 4 years negotiations, it obtained the green light from the WTO members, leading to the formal ratification by Georgia's Parliament in May 2000, thus freeing the way to become the WTO's 137th member on 14 June 2000. Georgia was the fourth former Soviet Republic joining the WTO after the Kyrgyz Republic, Latvia and Estonia (WTO Secretariat, 2015). In the early years of the transition, many countries in the region started to adopt liberal import policies, in many cases largely driven by willingness and policy objectives to join the WTO. The dismantling of the Soviet Bloc brought economic chaos and a collapse of trade flows, which compelled countries in Central and Eastern Europe to begin to reintegrate into the global economy. Georgia, as one of the three Caucasus countries, was no exception and determined to undertake the domestic reforms and adjustments to abide by the market-based principles. The objectives of trade liberalization, market opening and ensuring transparency were and still are at the heart of Georgia's reform policies (Broadman, H., G. 2005).

With trade being considered the main driver of economic growth, the main objectives of Georgia's trade policy are defined as follows:

1. Integration into the world economy, including the implementation of WTO membership obligations and obligations under other international agreements; 
2. Trade policy liberalization, including simplification of export and import procedures and tariff and non-tariff regulation;

3. Diversification of trade relations by establishing preferential regimes with main trade and regional trade partners;

4. Enhancement of transparency in the policy-making.

In order to pursue these objectives and as a new and Recently Acceded Member (RAM) of the WTO, the main challenges for Georgia consisted of continuing the reform process initiated during the accession process. It is considered to be the only way to take advantage of the benefits that WTO membership offers and to operate the system. The domestic reform process included a broad range of measures aimed at reducing transaction costs, easing business transactions, reviewing tax laws and regulations and enhancing transparency with a view of attracting foreign direct investment (FDI). In order to build such human and institutional capacity, support was provided both by the WTO Secretariat and bilateral donors (Smeets, M. 2013). Georgia's main reform initiatives target streamlining, liberalization and simplification of trade regulations and their implementation. All measures are geared towards enhancing competition, encouraging and facilitating trade, easing customs procedures, lowering import duties and reducing the incidence of non-tariff measures.

Fiscal and tax reforms: Some of the main reforms that were put into effect included the corporate income tax reform, enhancing easiness of tax compliance, enhancing stock exchange activities, the development of local capital market, a reform of the pension scheme, based on a private pension system, the introduction of transparent and efficient public-private partnership (PPP) framework, the creation of a public investment management framework, which should lead to an improved efficiency of state projects, stimulating private savings, strengthening the public trust in the financial system, enhancing the transparency and financial accountability and strengthening the protection of shareholder rights (European Commission, 2021).

More specifically with regard to tax and fiscal legislation, the Georgian tax system was simplified and tax rates were reduced. An easily administered, flat, and simple tax system was introduced. The number of different taxation schemes was reduced from 21 to only 6 types of taxes. These include corporate income tax, personal income tax, property tax and indirect taxes such as VAT, excise, and import duties. A new tax code entered into force on January 1, 2011, which incorporates both the tax and customs codes. Further improvements and innovations included the introduction of the status of micro, small business, the establishment of a Tax Ombudsmen, and the principle of good faith. All measures further strengthened the principles of transparency and accountability. Furthermore, the Georgian business licensing system was modernized and simplified and 'unnecessary' regulations, which often turned out to be a source of corruption were abolished. The number of licenses and permits necessary for doing business was reduced by almost $85 \%$ and the "single window" and "Silence is Consent" principles were introduced.

Hence, the author can answer the question: What are the benefits of Georgia's WTO membership for the EU and Georgian businesses? 
Accession of WTO contributed powerfully to stabilising Georgia's trade legislation and reinforcing domestic economic reform and therefore increasing the stability and predictability for EU businessmen exporting to, or investing in, Georgia. It is believed that Georgia's medium-term growth prospects depend on a number of factors, including its ability to take advantage of the free trade agreement with the EU. Georgia has conducted major structural reforms in order to achieve all its key objectives, i.e. the integration into the world economy, including the implementation of WTO membership obligations and obligations under other international agreements, trade policy liberalization, including simplification of export and import procedures and tariff and nontariff regulation, diversification of trade relations by establishing preferential regimes with main trade and regional trade partners and finally enhancing of transparency in the policy-making. These objectives for the major part continue to have the attention of the government and in many ways are considered as work in progress. Through its active participation in international trade, Georgia aims to diversify exports and benefit from MFN treatment granted by WTO members. Today Georgia is an active Member in the WTO, and has made substantive inputs in the negotiations of the DDA, including with specific text and negotiating proposals on technically complex issues with a view of directly serving its economic and trade interests at the multilateral level. It will actively continue doing so in pursuit of its economic development policy objectives. The WTO is described foremost as a trade-economic partnership-type institution with 164 member states. This is also advantage for Georgian exporters who will be better able to ensure their rights in doing business worldwide.

However, the authors argue, that there is a gap in the text of the Association Agreement in regard of the WTO; in particular, the Organization is referred to rather inconsistently and it seems that there is no unified vision on the name of the organization. The author believes, that the state should decide how to denominate such an important organization in the official documents, based on common practice of using terms of legal acts.

\section{CONCLUSION}

The analysis of the process of Georgia's economic integration into the EU leads to the conclusion that in this respect Georgia has no enforcement problem ensuing from concomitant obligations for one reason: the text of Georgia's Association Agreement repeatedly stresses respect for the WTO principles and treaties and their preferential legal force in the case of collusive norms.

The authors believe that one of the reasons for the special success of the WTO is systemic exceptions for developed countries and states with special needs that contributes to the development of international trade through progressive liberalization and the comparative advantage of the states when carrying out trade. This is especially important for a country like Georgia.

According to the authors, the example of Georgia shows very well that so far the country has not been able to actively apply all the advantages that can be used within the framework of international or regional 
organizations, at least for the simple reason that the country does not possess the appropriate infrastructure for bringing innovative products to foreign markets, and thus accumulate more economic wealth.

The authors claim that it is necessary for the state to take responsibility for the relevant procedures and promote the production of services or products in the country, in which the country will take its niche in the international space.

Finally, and to conclude, this case study evidences and confirms that while the accession process to the WTO is challenging per se, it is part of a process of domestic reforms that triggers growth and economic benefits. WTO's membership doesn't automatically lead to economic gains, which can only be obtained through hard work, a strong and continued commitment to undertake domestic reforms and put the right policy conditions in place to trade and attract FDI. It requires a vision, a strategy and a clear understanding of the country's potential and the political will and determination to put all the elements and conditions in place to create synergies.

Author Contributions: Conceptualization, G.A.; methodology, G.A.; formal analysis, G.A., V.Z; investigation, G.A.; project administration, G.A., M.P.; data curation, M.P; resources, V.T., V.Z., M.P.; supervision, G.A.; validation, G.A., V.Z; writing—original draft preparation, G.A; writing—review and editing, V.Z., V.T.

All authors have read and agreed to the published version of the manuscript.

\section{Conflict of interests}

The authors declare no conflict of interest.

\section{References}

Abuseridze, G (2020). Trade War: Georgia vs. Russia. Electronic Scientific Journal of Law Socrates. January 2020; SOCRATES Rīgas Stradina universitātes Juridiskās fakultātes elektroniskais juridisko zinātnisko rakstu žurnāls / SOCRATES Rīga Stradinš University Faculty of Law Electronic Scientific Journal of Law 3(18):147-154. DOI: $10.25143 /$ socr.18.2020.3.147-154

Baklanova, O., Petrova, M., Koval, V. (2020). Institutional transmission in economic development, Ikonomicheski Izsledvania (Economic Studies), 29(1), pp. 68-91

Broadman, Harry G. (2005) From Disintegration to Reintegration: Eastern Europe and the Former Soviet Union in International Trade. Washington, DC: World Bank. C) World Bank. https://openknowledge.worldbank.org/handle/10986/7511 $\quad$ License: $\quad$ CC $\quad$ BY $\quad 3.0 \quad$ IGO.// http://hdl.handle.net/10986/7511

European Commission (2021). EU-Georgia Deep and Comprehensive Free Trade Area (DCFTA). https://trade.ec.europa.eu/access-to-markets/en/content/eu-georgia-deep-and-comprehensive-free-trade-area

Georgian National Investment Agency (2021). Favorable Tax Regimes in the Country. https://www.pwc.com/ge/en/assets/pdf/june-2021/DBG\%202021_as\%20of\%2031\%20March\%202021.pdf

International Monetary Fund (2018). IMF Country Report. https://www.imf.org/external/pubs/ft/ar/2018/eng/

Matyushenko, I., Hlibko, S., Petrova, M., Khanova, O., Loktionova, M., Trofimchenko, K. (2021). Assessment of technological competitiveness of Ukraine in terms of association with the EU. Ikonomicheski Izsledvania (Economic Studies), ISSN 02053292, 30(7), pp. 148-176 
Matyushenko, I., Hlibko, S., Petrova, M. M., Pasmor, M. S., \& Loktionova, M. (2020). Assessment of the development of foreign trade in high-tech production of Ukraine under the association with the EU. Business, Management and Education, 18(1), 157-182. https://doi.org/10.3846/bme.2020.11578

Ministry of Finance of Georgia (2018). Georgia - The outlook. https://www.mof.ge/images/File/Georgia-TheOutlook_ENG_Apr-2018.pdf

Smeets, M. (2013). Trade Capacity Building in the WTO: Main Achievements since Doha and Key Challenges. Journal of World Trade. Volume 47, Issue 5, pp.1047-1090, https://kluwerlawonline.com/journalarticle/ Journal+of+World+Trade/47.5/TRAD2013035

World Bank (2018). Doing Business 2019: A Year of Record Reforms, Rising Influence. https://www.worldbank.org/en/news/immersive-story/2018/10/31/doing-business-2019-a-year-of-record-reformsrising-influence

World Bank (2014). Annual Report. https://www.worldbank.org/content/dam/Worldbank/AR14_OperationalHigh lights.pdf

WTO Secretariat (2015). Trade Policy Review, Report by Georgia, WT/TPR/G/328. (15-5924). Page: 1/13. https://www.wto.org/english/tratop_e/tpr_e/s328_e.pdf

World Trade Organization (1999). WTO Report of the Working Party on the Accession of Georgia to the World Trade Organization WT/ACC/GEO/31. https://docs.wto.org/dol2fe/Pages/SS/directdoc.aspx?filename=Q:/WT/ACC/ GEO31.pdf\&Open=True

\section{About the authors}
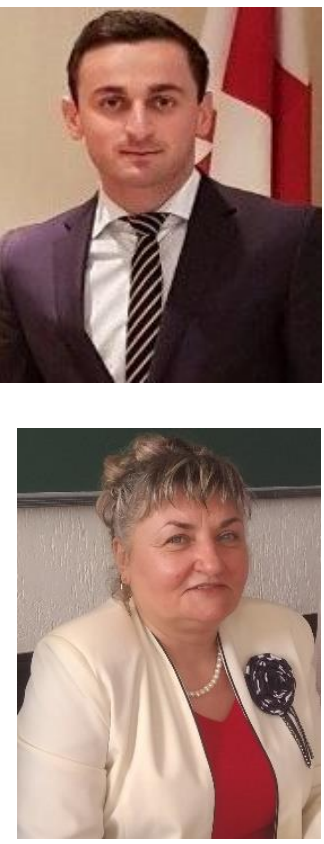

\section{Giga ABUSERIDZE}

Ph.D in Law, researcher and lecturer at Riga Staradins University since 2015.

His research profile is focused on international trade issues, transformation of trade system, WTO, DCFTA etc. One of his main areas of interest is also Law and Diplomacy. He is the author 25 scientific papers (also published in Scopus and WoS), several policy papers and international research projects.

ORCID ID: https://orcid.org/0000-0003-2868-8719

\section{Mariana PETROVA}

Professor, PhD in Physics and Mathematics, assoc.prof. St. Cyril and St. Methodius University of Veliko Tarnovo, Bulgaria; Professor Economics and Management in Department of Management, ISMA University, Riga, Latvia.

Research interests: management of IT processes, project and services, business administration, modern information systems and innovations, knowledge economy, sustainable development.

ORCID ID: https://orcid.org/0000-0003-1531-4312 

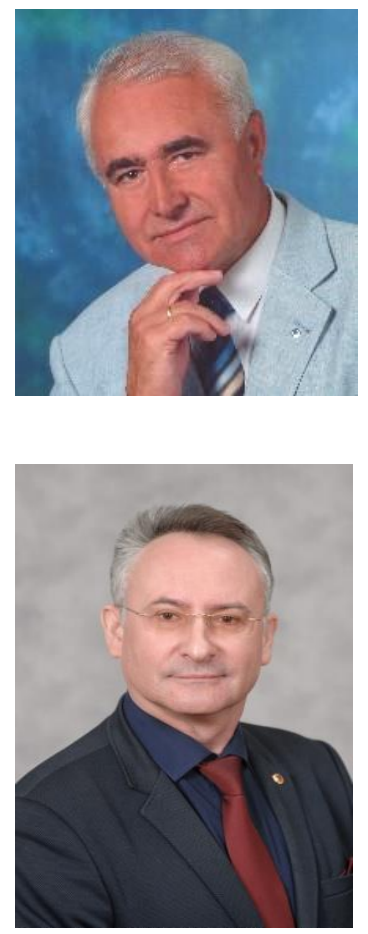

\section{Vitolds ZAHARS}

Professor, Dr. iur., Head of Law Department Faculty of Social Sciences Daugavpils University, Daugavpils, Latvia. He is the author of 14 books (6 monographs and 8 text books) and more than 100 scientific articles.

Research interests: Criminal Policy, Criminal Law, Crime Determinants, Penology, European Human Rights, Globalisation

ORCID ID: https://orcid.org/0000-0003-1100-0519

\section{Vladas TUMALAVIČIUS}

Dr. iur. Lecturer at General Jonas Žemaitis Military Academy of Lithuania, Research Group for Security Institutions Management

Research interests: Legal Regulation of Public Safety and Administration; Issues of National, State and Regional Security and Sustainability; Regional Economics Security.

ORCID ID: https://orcid.org/0000-0002-0811-0074

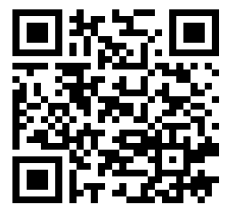

Copyright (C) 2020 by author(s) and ACCESS Publishing Press This work is licensed under the Creative Commons Attribution International License (CC BY) 


\title{
INNOVATION RESEARCH MODEL FOR COMPETENT PROFESSIONAL COMMUNICATION IN A FOREIGN LANGUAGE FOR POSTGRADUATE SCHOOL LAWYERS
}

\author{
Elmira Uteubayeva \\ Karaganda Buketov University, Karaganda, Kazakhstan \\ e-mails: utb.elmira@gmail.com,elmira5555@mail.ru
}

Received:09 December 2021 Accepted:28 December 2021 Online Published:30 January 2022

\begin{abstract}
The article is devoted to the problem of improving the quality and efficiency of foreign language teaching methods in the system of postgraduate education. The author proposes a methodology for developing professional reading skills in the context of teaching professional English communication for law students using pragma-professional technologies. Professionally oriented reading of legal novels contributes to developing scholars': intellectual potential, integrated professional competence, socio-cultural knowledge, professional outlook, and creative abilities.

Objectives: to substantiate the need to improve the effectiveness of lawyer's communicative competence in a foreign language by developing a methodology for the formation of various educational strategies based on a literary work of a legal orientation within the framework of the course "Language for Specific Purposes, " which combines the principles of communicative, interactive learning using innovative technologies.

Methods / Approach: In order to solve the objectives, methods were used such as: theoretical (conceptual and terminological analysis of basic definitions, modelling, system analysis) and empirical methods (diagnostic tests for postgraduates and teachers, experimental sections for, observations, comparison, analysis and systematization of experiment data).

Conclusion: the reading effectiveness in a foreign language is increased when teaching law postgraduates law to read works of art in a foreign language based on a specially developed strategy.

Keywords: communicative approach, research model, innovations in educational management, English for Specific Purposes (ESP), specialised reading, independent work, efficiency.

JEL classification: A23; A39; K00

Citation:

Uteubayeva E. (2022). Innovation research model for competent professional communication in a foreign language for postgraduate school lawyers. Access to science, business, innovation in digital economy, ACCESS Press, 3(1): 53-66. https://doi.org/10.46656/access.2022.3.1(5)
\end{abstract}

\section{INTRODUCTION}

Kazakhstan's entry into the world community, the establishment of democratic values, and the development of a market economy pose a difficult task for the education system - to prepare a competitive specialist who can creatively comprehend the processes in the public and professional sphere; fully applied to the problems of 
modern legal theory and practice, the development, due to the orientation of the legislative and regulatory framework of the Republic of Kazakhstan.

Following the Concept for the Development of Education in the Republic of Kazakhstan until 2025, it is planned to determine strategic priorities in developing a national model of multi-level continuous education. A modern Kazakhstani lawyer should receive legal knowledge and opportunities to develop tactical, communication, and psychological skills in expanding international cooperation and cultural globalization (Government program of development of education and science of the Republic of Kazakhstan for 2020 2025, 2019). The developed concept of lifelong education implies regular updating and expanding the knowledge base throughout life. This concept was adopted by the Commission of the Council of Europe on Higher Education and Research within the program "University of Tomorrow: Higher Education Policy in Europe." It is associated with the constant improvement of a specialist qualification (Arthur, Brennan \& de Weert, 2007). The analysis of several documents of the Council of Europe on education and specialists training indicates that the Common European Community is pursuing a targeted policy focused on the development of the ability for specialists to freely and professionally communicate in a foreign language within their field (DeBoer, 2000).

Recently, issues related to the problems of professional training and the formation of specialist's communicative competence have been widely studied by foreign and domestic scientists (Arias Rodríguez, 2014; Abolina \& Akimova, 2012; Nenkov et al, 2017; Alyousef, 2005; Burns, 2003; Butler-Pascoe, 2009; Gatehouse, 2001; Mohamed Rhalmi, 2010; David Beswick, 2017; Campbell et al, 2000; Brown, 2000; Romenville, 2004; Goncharova, 2007).

Researchers also consider a wide range of problems related to communicative competence and improvement of teaching methods of foreign languages, revealing the potential for establishing various specialists' communicative competence in a foreign language (Frey, Balzer \& Renold, 2002; Petrova, Uteubayeva, Kokhanover, 2020; Orumbayev, 2004; David J. Flinders, 2015; Drs. Suharno, 2017; Stoof et al, 2002; Westera, 2001; Ramos \& Luque, 2010).

Despite the apparent difference in theoretical approaches, most authors agree on one essential statement: one of the essential aspects of the professional competence of specialists in their communication skills, in particular, a foreign language competence. The study of such problems has already set a specific trend. At the same time, this problem in the professional training of lawyers in the postgraduate education system needs to be found in the search for effective and evidence-based solutions in the development of appropriate didactic support.

In the context of our study, this is projected onto the problems of lawyers' professional communication, which plays a paramount role in their career and inevitably involves people interaction: the process of interpersonal communication, negotiations between a lawyer and interested parties, court cases, decisions of competent authorities. Therefore, a lawyer's training should essentially focus on the development of their 
professional communication skills both in their native and foreign languages. The formation of types of speech is determined by the subject area of law making and law enforcement and requires a transition from the informative methods of foreign language teaching to problem-solving, creative, and pragma-professional technologies. The most critical condition to success in forming postgraduate lawyers' communicative competence in a foreign language is to consider their scientific interests and academic motives.

Purposeful acquaintance with the experience of law schools, the study of the initial state of lawyers training at the postgraduate institutions of the Committee of National Security and the Ministry of Internal Affairs of the Republic of Kazakhstan allows us to state that the methodology for teaching professional language communication in a foreign language requires improvements. There is a severe insufficiency of modern alternative textbooks, supporting and methodological improvements, reflecting not only the specifics of professional communication in a foreign language of legal professionals but aimed at forming specialist's linguistic personality, ready for intercultural communication (Order of the Minister of Education and Science of RK, 2018). In our opinion, the lack of demand for a foreign language across lawyers insufficient development of self-teaching methods of a foreign language that would take into account the specifics of foreign language for lawyers in postgraduate education. Upon a thorough study of the educational and methodological base for independent work of postgraduates within the framework of lawyers postgraduate education, we concluded that there are no developed manuals for an independent study of legal terminology.

The formation of communicative competencies is presented within the educational manual "Legal specialties master students Textbook (Language for specific purposes)," comparing legal systems of the United States and Kazakhstan. The integrity of the legal novel as a work of art helps to perceive the content from a professional point of view. Such a feature of the work contributes to the lawyer's cognitive abilities, critical thinking, and desire to comply with the mission of serving the law and society. According to M. Halbwaks, "Education is the most effective tool by which the state molds people in its own image" (Krubelye, 1989). The Kazakhstani society, standing on the path of global transformations, is forming a new social order for the entire domestic education system - to grow an accessible, well-rounded, and independent persons capable of intellectual curiosity and creative solutions.

There are objective limitations on the scope of methodological goals and ambitions when teaching communication in the target language. Insufficient language training of postgraduates, uncertainty, limitations to self-expression, control of the process force teachers to constantly intervene in linguistic and communicative plans. This can lead to the emasculation of communication, reducing it to simple and primitive dialogic language with a bit of lexical and grammatical correctness.

Optimization of professional postgraduate competence in communication assumes that the applicants can determine their position in the upcoming interaction, goals, and objectives to extrapolate on potential action scenarios.

The very process of interpersonal interaction is also described in terms of methodologies, which include: 
- establishing contact based on an assessment of one's position, the position of the interlocutor, and the meaning of the conversation;

- fixing the position of the addressee of the conversation (includes the motivation to transfer information, its differentiation, establishing a connection with the subject and goals of the conversation, its sufficiency, and plausibility, reliability.);

- formulation and justification of one's position (i.e., designation of the subject of the conversation, which is mandatory; an indication of the competence and capabilities of a lawyer; putting forward proposals or requirements, the volume, and nature of which may change);

- opposition (questions, additions, elements of controversy, impact on the argumentation of the addressee of the conversation, i.e., addition of the interlocutor or objection to him);

- reaching a common conclusion

In addition, as part of the general professional training of a lawyer, it is necessary to pay attention to and work out the general rules of behaviour and communication. These include techniques that are honed through special training and targeted training such as showing self-confidence, reliability, goodwill, solidity; the ability to inspire a partner with a sense of greater security, freeing him from fear, feelings of hopelessness or uncertainty, prompting him to take the right action, etc.

In extracurricular independent work, the student is faced with the need to mobilize the ability to generalize the received information turning it into knowledge. The psychological result is even more critical. In the process of independent work, a student constantly feels like a person who can independently make decisions and bear responsibility. Eventually, an individual possesses such qualities. Independent work necessarily implies the ability of self - organization, and therefore the inclusion of independent work in the curricula sets a fundamentally new stage in the organization of the educational process.

Thus, reading a legal novel in a foreign language may contribute to expanding cultural and professional horizons. Reading supports understanding the content, synthesizing, and analyzing the author's point of view (Bakhtin, 1976). There are both contextual and procedural qualities that can be developed (the correct pronunciation of the text) due to different types of reading:

- analytical reading (translated and untranslated);

- prepared or unprepared reading;

- reading aloud or reading to oneself;

- intensive and extensive reading;

- brief reading

The hypothesis of the study is: if theoretically substantiate, develop and implement a methodology for the formation of foreign language communicative competence of lawyers through the activation of professional reading, then the quality of their foreign language, in general, will increase since the content and technological components of the manual will be aimed at implementation of the continuous foreign language education. 
In this study, when solving methodological problems, special attention is paid to the formation of communicative competence in the space of interdisciplinary research activity of the applicant, which allows teachers to choose ways to achieve their goals, depending on the specific conditions, level of language proficiency prior to the start of the course.

The following objectives were set during the study:

1. To study the state of the problem of teaching analytical reading;

2. To identify, classify and present a list of skills necessary for analysis and interpretation in the process of analytical reading of a work of art;

3. To determine the stages of work necessary to create a set of exercises aimed at developing analytical and interpretive competencies, including the skills of analytical reading and thinking;

4. To select a text for analytical reading, taking into account the goals, objectives, conditions of study, the level of foreign language proficiency of postgraduates;

5. To determine the difficulties of teaching analytical reading by questioning and interviewing both scholars and teachers, to develop a legal dictionary to remove lexical difficulties, based on the selected text;

6. To develop a scientifically based set of techniques and exercises, as well as a training model aimed at developing the identified skills;

7. To experimentally check the effectiveness of the developed methodology in practical training.

\section{METHODOLOGY}

The study was conducted at the Faculty of Foreign Languages at Karaganda Buketov University. LSP is a part of the university's curriculum, so the programs require master students to develop reading comprehension abilities in their subject; given this requirement, they have to practice reading about professional topics in their field of study.

Practical training was aimed to compare the level of professional communication skills and abilities of master students of the experimental groups with the level of master students of all other postgraduates, i.e., the control group. It seems possible to consider the hypothesis proven if the level of professional communication skills and abilities of master students of the experimental groups meets the requirements of the State Educational Standards and the experimental training program, and also if the level of foreign language communicative competence is not lower than the level of master students of the control groups, assessed by the identical parameters.

\section{A. General characteristics of the subjects}

The subjects were postgraduate students of the Faculty of Law and adjuncts of the Karaganda Law Institute of the Ministry of Internal Affairs of Kazakhstan. To select the experimental groups, we used the results of the 
standard input control (lexical and grammatical tests), which are passed by postgraduates who wish to study "Language for Specific Purposes." We set three groups with firm, medium, and weak (passed the entrance test with a minimum number of points) language levels for the practical training. The control was carried out on the level of language and communicative-speech competence.

\section{B. Conditions for experiential learning}

a. Non-Variable Conditions:

Topics and language material were selected in accordance with textbooks for lawyers (authentic material).

b. Variable conditions:

Teaching postgraduates professional communication skills and abilities on the basis of an experimental program - professionally oriented reading.

c. Learning material

Experiential learning was based on a program compiled by us for an extracurricular self-study with some teacher supervision. Other activities include role-playing, business games, and quasi-professional activity or problem situations, including their analysis.

The main stages of training:

1. Preparation and ascertaining section.

a. monitoring the educational activities of postgraduates, adjuncts, and applicants-lawyers;

b. studying the experience of colleagues;

c. the analysis of literature data on research problems.

2. Experiential learning.

3. Post-experimental section.

In order to form communicative competence, the teaching manual was chosen to be based on John Grisham's work "The King of Torts". The developed manual consists of 42 chapters. Students are offered to read the electronic version of the novel in English chapter by chapter. A link to audio materials is given to improve phonetic and pronunciation skills. The manual contains a professional lexicon, models of spoken language, phraseological expressions, and interpretation of legal terms. Each chapter contains exercises and assignments for four types of spoken activity (reading, vocabulary, comprehension, writing) and the development of digital competence, working with Internet resources. The manual encompasses three languages of study: English, Kazakh, and Russian. The Kazakh language was included taking into account the training of scholars in the state language. As an example, Chapter 1 of the manual (Appendix 1) is attached. All tasks were substantiated by the criteria for the formation of the language competence of lawyers, which are determined;

1. the level of proficiency in grammatical and linguistic units;

2. the ability to assess and fix the position of the interlocutor (or opponent) in communication;

3. the ability to evaluate and maintain one's position in communication; 
4. skills and abilities to oppose different opinions.

The second criterion characterizes the formation of the ability to assess and fix the position of the interlocutor (or opponent) in communication and manifests in such indicators as the ability to highlight the semantic parts and the logic of constructing the interlocutor's text; the ability to correlate the speech of the interlocutor with the subject and goals of the conversation; the ability to assess the sufficiency and reliability of the given argumentation, the ability to understand the intention of the interlocutor.

The third criterion characterizes the formation of the ability to evaluate and maintain one's position and manifest in the following indicators: the ability to clearly, concisely, and logically formulate one's position; the ability to argue one's speech (the adequacy of the text to the topic of discussion and the position taken in communication; the variety and evidence of arguments).

The fourth criterion, which characterizes the formation of skills to oppose, is manifested in such indicators as the ability to ask questions (clarifying and suggestive); the ability to use the interlocutor's arguments in polemics without allowing a dispute; ability to reach a common conclusion.

\section{RESULTS}

The preparation stage convincingly proved the need to search for new approaches to teaching professional communication in a foreign language, which consists of the skills and abilities to work with a scientific text, extract the information and make summaries taking into account the specialty. During the preparatory phase, factors both contributing to and hindering the effectiveness of the English language teaching process at the postgraduate stage were carefully studied. These include the following:

1. factors contributing to the effectiveness of the learning process:

a. the standard degree of trainees' knowledge of unique legal terminology;

b. the high degree of motivation and activity;

c. "maturity" of the individuals' mentality.

2. factors hindering the effectiveness of the learning process:

a. insufficient amount of free time to achieve the level of fluent scientific knowledge of a foreign language and the processing of monographs and scientific materials necessary for research activities;

b. different levels of English proficiency among postgraduates;

c. low level of digital competence of postgraduates to complete tasks and search for relevant information in scientific databases;

d. methodical unpreparedness of most teachers to conduct classes in a foreign language in nonlinguistic universities at the postgraduate stage.

In developing a program for experiential learning, the above factors were further implemented. 
The ascertaining section consisted of two parts. The first part was a diagnostic test offered to all students at the postgraduate stage who studied English at the university to distribute them into groups of the appropriate level. This took into account not only the knowledge of vocabulary, grammar, and fluency of speech (in oral answers) but also the "maturity of the mentality," the willingness to independently think critically and logically argue one's point of view.

Based on the results of the ascertaining section, the following conclusions were drawn:

Master's students, in general, have sufficient oral and written skills to investigate the formation of professional, communicative competence at the postgraduate stage.

The experimental work was quite effective: there was an increase in postgraduates with a high and medium level of foreign language communicative competence formation. The research data indicate that the experimental work was quite effective: its result was an increase in the number of postgraduates with a high level of formation of foreign language communicative competence:

- in the first criterion, it grew by $16.0 \%$;

- in the second case - by $19.6 \%$;

- in the third - by $26.8 \%$;

- in the fourth - by $17.8 \%$ (compared the initial and final indicators of the high level of the experiment).

The data of the transforming stage indicate that the highest indicators, stating the level of formation of foreign language communicative competence, were recorded by us at the third stage of diagnosis (Figure 1, Figure 2 and Figure 3).

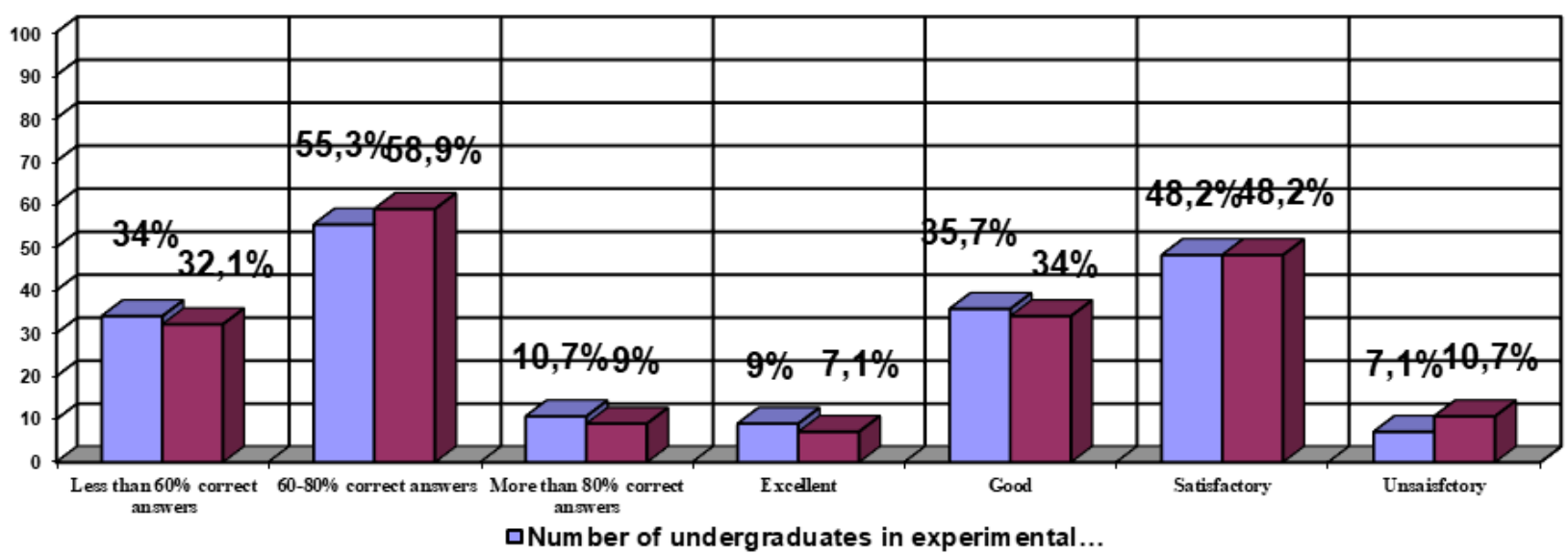

Figure 1. The results of the first ascertaining test 


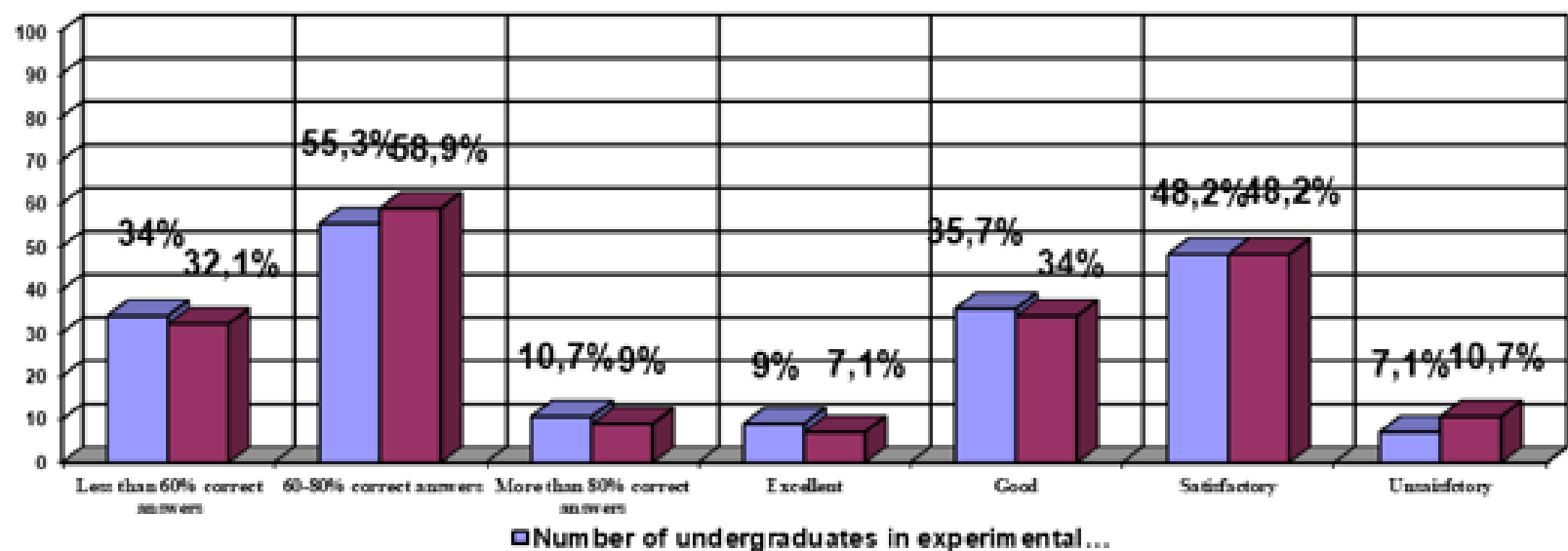

Figure 2. The results of the second ascertaining test

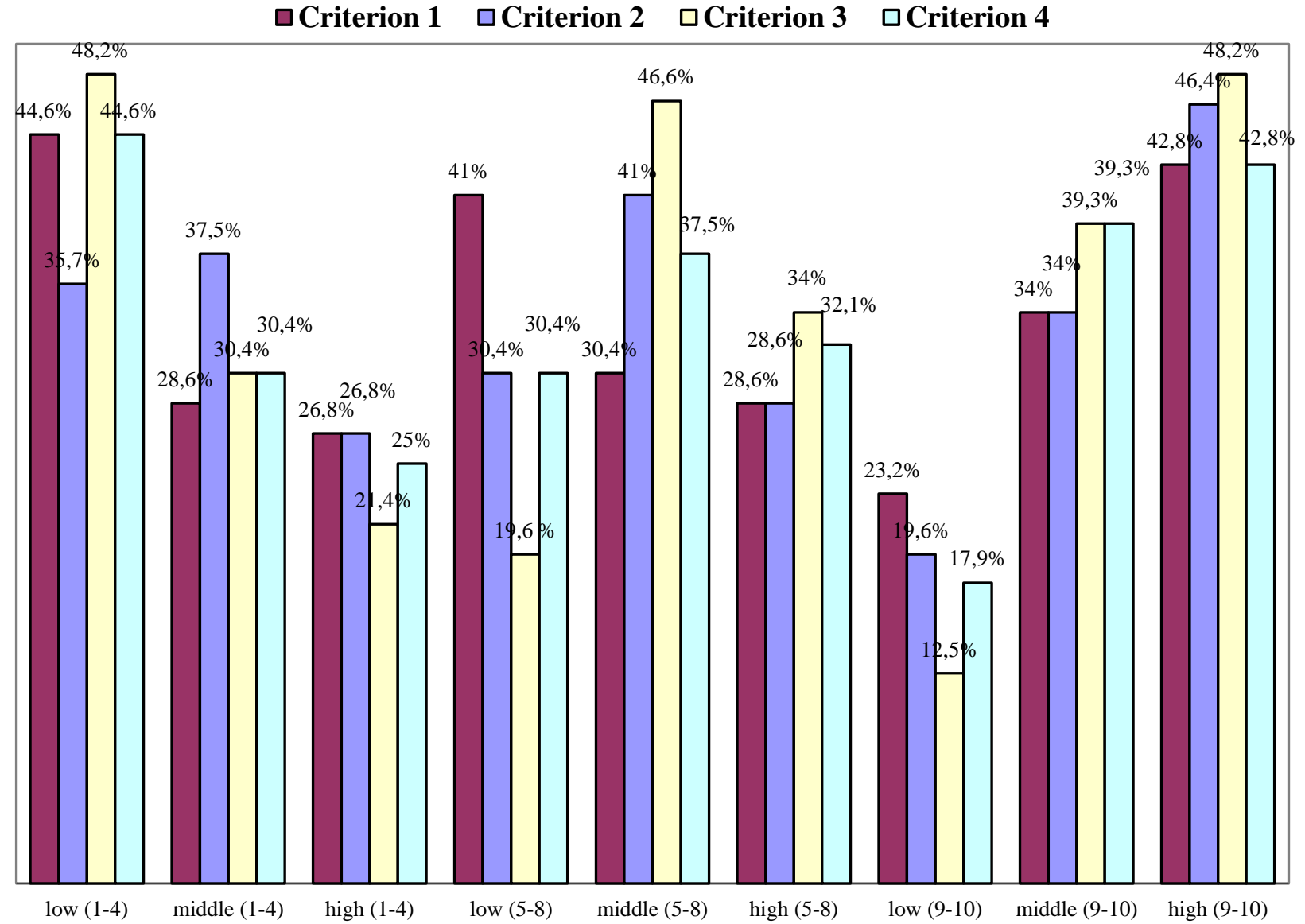

Figure 3. Analysis of the results of experimental training.

Diagnostics of the formation and improvement of the foreign language communicative competence of lawyers at the postgraduate stage and the quantitative and qualitative results of the educational activities of the trained experimental groups showed several positive changes (Figures 4). So, already at the second stage, most 
of the master students of the experimental groups showed the ability to fix, argue and maintain their position in the process of professionally oriented communication, the ability to formulate clear conclusions, the ability to communicate in the given forms of organization of statements, the ability, and skills to oppose.

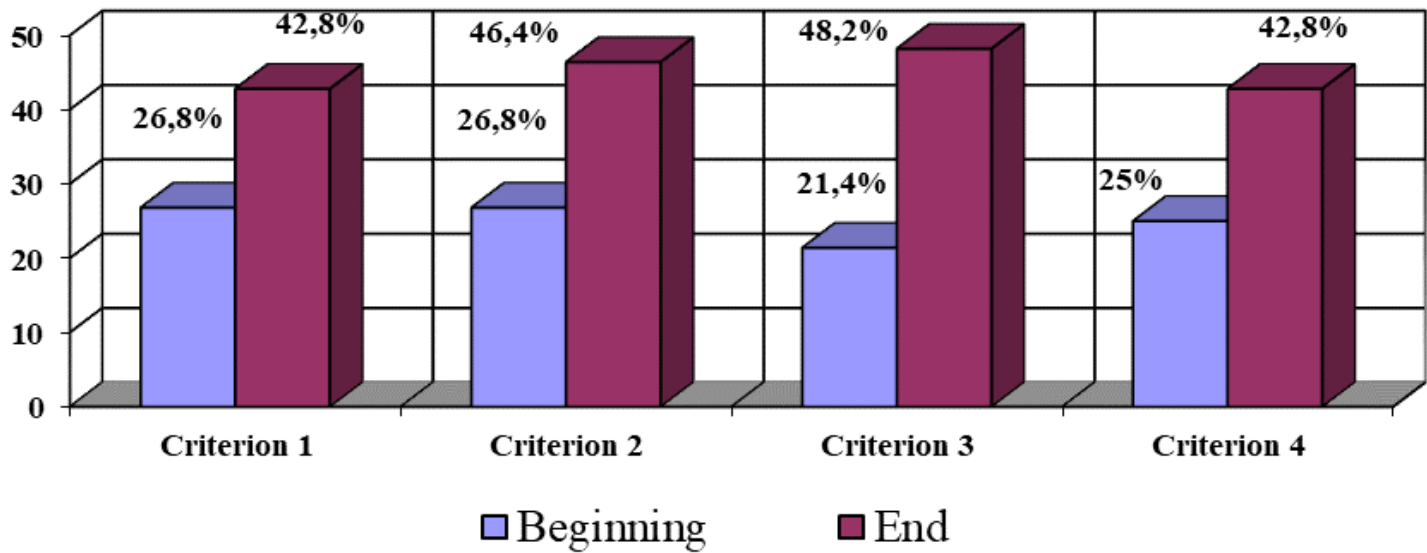

Figure 4. Dynamics of the number of postgraduates with a high level of proficiency in foreign language communicative competence

The practice of teaching lawyers has shown that the effectiveness of training increases if, in addition to contextual learning, learning technologies are based on fictional legal literature topics. A feature, in this case, is the stimulation of the searching abilities, which students somewhat found unusual and thus stimulated the effectiveness of training. When using this learning model, the teacher does not simply provide the information. Instead, by constantly challenging the view, reflecting on the topic, and providing substantial proofs with crucial ideas and algorithms, the learning abilities of master students are activated to a different level.

\section{DISCUSSION}

Reading fiction, namely legal novels, helps to expand the horizons of postgraduates, shaping the ability to analyze information and communication skills. Choosing legal novels for compiling a manual for independent reading, we proceeded from the principle of accessibility, artistic expressiveness, the brightness of characters, originality of the logic of presentation, and also taking into account interdisciplinary connections with other branches of law.

A variety of tasks were compiled to work with: lexicon, tasks for critical and creative thinking, problemsolving, people management, communication and emotional intelligence, decision making, customer focus, negotiation, cognitive flexibility, stress resistance. These exercises propose analyzing information, interpreting data, and establishing a causal relationship of certain types of crimes described in the novel. A written essay is required for a holistic comprehension of the acquired material by the end of each chapter. Speech patterns 
and phraseological phrases found in the novel serve as a meaningful purpose to support the logical and reasoned construction of the speech. The study of legal terminology arouses the student's interest and understanding of the need to study specialization on a deeper level. The terminology used in the field of law makes comparisons and analyses of the information and therefore contributes to the research skills necessary not only for mastering foreign language vocabulary but knowledge acquisition in other social sciences. Students recognize the importance not only of procedural norms but also psychological reasons. Since lawyers directly contact people, the manual develops essential interpersonal and communicative skills required for this specialty. From a professional point of view, reading chapter by chapter, the individuals cannot ignore professional mobility, the quality of generating brand-new areas in legal regulation. Thus, reading legal novels helps increase the motivation of postgraduates to study the law and related areas such as psychology, logic, and, in particular, a foreign language. From the preceding, we can conclude that home reading is an integrating link in teaching a foreign language, contributing to the scholars' intellectual potential, critical and creative thinking skills.

In the learning process, we discovered the fact that the effectiveness of the formation of foreign language communicative competence of lawyers in the system of postgraduate education largely depends on the application of a problematic approach based on the relationship of problem situations and tasks, as well as on a particular sequence of stages:

- the acquisition of knowledge (theoretical and cognitive methods)

- development of speech skills and abilities (the communicative-activity method dominates)

- development of professional communication skills (preference is given to problem-based learning methods)

Modelling the process of forming the foreign language communicative competence of lawyers in the postgraduate education system determined the specifics of the corresponding methodology, the leitmotif of which is the idea of problem-based learning. It is to this idea that all the components of this technique are subordinated. The problematic approach is based on a unique organization of scholars' actions to understand and resolve a problem situation, to find ways to solve problematic tasks of varying degrees of complexity based on previously acquired experience.

The methodological basis for constructing classes of various types that provide for problem-based learning is the standard requirements for organizing classroom classes:

- determination of the goals and objectives of the classes (goals for the development and improvement of language, communicative and professional communicative competence are prescribed separately);

- determination of the goals of actions performed to solve problematic tasks and situations;

- the choice of a method of action for the implementation of problem situations (the choice of the algorithm of work and the type of work, depending on the stage of work on the thematic series); 
- evaluation of the result of actions following fixed criteria for each type of work.

\section{CONCLUSION}

Summing up the results of the study, we came to the following conclusions:

1. The state of training of masters in jurisprudence is determined by the fact that it involves a revision of traditional teaching methods and techniques, shifting the emphasis in training to practical training, to the ability to navigate in the changing conditions of scientific and professional activities.

2. This revision of the methods and techniques of teaching lawyers should be guided by recognizing the evidence of the inseparable connection between language and jurisprudence.

3. Integration processes with the world community determine the actualization of foreign language training of lawyers in general and in the postgraduate education system in particular.

4. The purpose of postgraduate teaching of a foreign language is to form a foreign language communicative competence.

The conducted research and the results of experimental work make it possible to make a number of recommendations on the formation of a foreign language communicative competence of lawyers in the system of postgraduate education to be widely used:

- developed by us and tested methodology for the formation of foreign language communicative competence of lawyers in the system of postgraduate education;

- when teaching a professionally oriented foreign language to postgraduates, a published and tested manual for postgraduates "Legal specialties master students Textbook (Language for specific purposes)".

Thus, the identified positive trends in the formation of foreign language communicative competence in the system of postgraduate education indicate the need for further development of the problem, both at the theoretical and practical levels. Thus, the development of methodological support for the process of forming the foreign language communicative competence of postdergraduates of all non-linguistic specialties is subject to further research, which, in our opinion, involves the creation of a professionally oriented English course for students in the system of postgraduate education, and a number of thematic special courses focused on optimising interdisciplinary connections and professional communication skills.

Institutional Review Board Statement: The study was conducted according to the guidelines of the Declaration of Helsinki and approved by the ethics committee of the Buketov University

Informed Consent Statement: Informed consent was obtained from all the participants involved in the study. 
Data Availability Statement: The data presented in this study are available on request from the corresponding author. The data are not publicly available due to privacy issues.

\section{Conflict of interests}

The authors declare no conflict of interest.

\section{Acknowledgement}

I want to express my gratitude to the teachers and postgraduates who took part in the experiment, to the reviewers of the manual.

\section{References}

Abolina N.S., Akimova O.V. Communicative Competence Development in the Course of Vocational Training. The Education and Science journal. 2012;1(9):138-157. (In RU) https://doi.org/10.17853/1994-5639-2012-9-138-157

Arias Rodríguez, G. L. (2014). Reading through ESP in an undergraduate law program. PROFILE Issues in Teachers' Professional Development, 16(1), 105-118.

Alyousef, H. S. (2005). Teaching reading comprehension to ESL/EFL learners. The Reading Matrix, 5(2), $143-154$. Retrieved from http://www.readingmatrix.com/articles/alyousef/article.pdf

Arthur L., Brennan J., de Weert E. (2007). Employer and higher education perspectives on graduates in the knowledge society. A report from the European Commission Framework VI project: "The Flexible Professional in the Knowledge Society". Retrieved from http://www.open.ac.uk/cheri/pages/CHERI-Reports-2007.shtml

Bakhtin M. M. (1976). The problem of text (experience of philosophical analysis // Problema teksta (opyt filosofskogo analiza). Voprosy literatury. N.p. Vol 10, pp. 125 - 126 [in RU].

Brown, D. (2000). Principles of language learning and teaching. (4th ed.) White Plains, NY: Longman.

Burns, A. (2003). Collaborative action research for English language teachers. Cambridge, UK: Cambridge University Press.

Butler-Pascoe, M. E. (2009). English for specific purposes (ESP), innovation, and technology. English Education and ESP, 1-15. Retrieved from http://www.ouralliant.com/mbutler/Monograph_Taiwan2009.pdf

Campbell, B., Kaunda, L., Allie, S., Buffler, A., Lubben, F. (2000). The communication of laboratory investigations by university entrants. Journal of Research in Science Teaching, 37, 839-853.

David Beswick. (2017). Cognitive motivation. [From curiosity to identity, purpose and meaning]. Cambridge University Press, DOI: https://doi.org/10.1017/9781316822920.015. pp 317-368

DeBoer, G. E. (2000). Scientific literacy: Another look at its historical and contemporary meaning and its relationship to science education reform. Journal of Research in Science Teaching, 37, 582-601.

David J. Flinders (2015). Curriculum and Teaching Dialogue (CTD) Vol.17

Gatehouse, K., (2001). Key issues in English for specific purposes (ESP) curriculum development. The Internet TESL Journal, 7(10). Retrieved from http://iteslj.org/Articles/Gatehouse-ESP.html

Goncharova N.L. (2007). Categorie "competence" in the modern educational paradigm. North Caucasus: Collection of scientific papers, № 5. Retrieved from http: // www.nestu.ru. [in RU].// Kategorii "kompetentnost” I "kompetentsiya" v sovremennoi obrazovatelnoi paradigm

Frey A., Balzer L.\& Renold U. (2002). Soziale kompetenz und persönlichkeit: zusammenh ängezwischen sozialer kompetenz und den Big Five der person lichkeitbeijun generwachsenen. New York: Basic Books. Retreated from ISBN 393733959, 9783937333953Mohamed Rhalmi (2010). Communicative activities. pages.com/blog/englishwebsite 
Krubelye M. (1989). Education - 50/50: Vocabulary Experience of New Thinking // Obrazovanie - 50/50: Opyt slovarya novogo myshleniya. Moscow: Progress [in RU].

Nenkov, N., Dyachenko, Yu., Petrova, M., Bondarenko, G., Pustovit, V. (2017). Intelligent and Cognitive Technologies in Education of International Economic Relations Students and Human Resource Development in Enterprises: Methodology in Language. European Journal of Sustainable Development, Publisher: European Center of Sustainable Development, ISSN 2239-5938 (print), ISSN 2239-6101(online), http://www.ecsdev.org/, Rome, Italy, Vol 6, No.4, 2017, pp.353-360, https://doi.org/10.14207/ejsd.2017.v6n4p353

Petrova, M., Uteubayeva, E., Kokhanover, T. (2020). Didactic approach to the process of communicative competence formation. Bulletin of the Karaganda university/ Pedagogy series. ISSN 2518-7937 (Print). ISSN 2663-516X (Online). № 4(100)/2020. http://dx.doi.org/10.31489/2020Ped4/79-84

Order of the Minister of Education and Science of RK (2018). "On Approval of the mechanism for targeted training of Master's and PhD Doctors in Basic Higher Educational Institutions (with amendments and additions dated October 8, 2018), No. 235 [in RU].

Orumbayev Zh. B. (2004). Interpretation of the norms of law in the law enforcement process. Extended abstract of candidate's thesis, - Almaty: p. 119 // Tolkovaniye norm prava v pravoprimenitel'nom protsesse [in RU].

Ramos M. M., Luque G. (2010). A competence-based constructivist tool for evaluation. Cultura y Educación, 22 (3), pp. 329-344.

Romenville M. (2004). Competence approach in university education: objectives, benefits, boundaries [Presentation, AMUE seminar "LMD Diplomas in Competence Terms and Presentation of the Diploma Supplement"], Paris

State Program for the Development of Education and Science of the Republic of Kazakhstan for 2020-2025 (Decree of the Government of the Republic of Kazakhstan dated December 27, 2019 No. 988) (RUS) (as amended on December 27, 2019)

Suharno, M. Ed (2017). Language in scientific writing. [Fakultas Sastra]. Retrieved from: https://core.ac.uk/download/pdf/11704727.pdf

Zhetpisbayeva B.A., Uteubayeva E.A. (2012). English for postgraduates in Legal specialties //Angliyskiy yazyk dlya magistrantov yuridicheskikh spetsialnostey. Uchebnoye posobiye [Workshop], Karaganda: Izdatelstvo Kargu, p. 13.

StoofA., MartenR., Van MerrienboerJ. \&Bastiens T. (2002). The Boundary Approach of Competence: a Constructive Aid for Understanding and Using the Concept of Competence. Human Resource Development Review, 1 (3), pp. 345365

Westera W. (2001). Competences in Education: a Confusion of Tongues. Journal of Curriculum Studies, 33 (1), pp. 75 88.

\section{About the author}

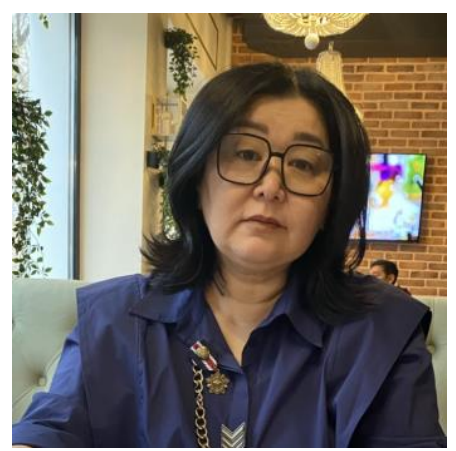

\section{Elmira UTEUBAYEVA}

Candidate of pedagogical sciences (26.02.2011) (Kazakhstan, Astana)

$\mathrm{PhD}$ - Theory and management of education (Bulgaria, Sofia)

Professor of the Russian Academy of Natural Sciences (26.02.2013) (Russia, Moscow)

Associate professor of Department of Theory and Methodology of Foreign Language Training, Academician E. A. Buketov Karaganda State University, Karaganda, Kazakhstan

Research interests: innovations in educational management, Pedagogical acmeology, Research in Education (in English), Scientific research methodology, Accreditation and assessment, Project activities, Source studies, Language for Specific Purposes (Jurisprudence)

ORCID ID: https://orcid.org/0000-0002-1648-114X

Copyright (C) 2020 by author(s) and ACCESS Publishing Press This work is licensed under the Creative Commons Attribution International License (CC BY) 


\title{
CULTURAL TOURISM DEVELOPMENT IN THE TOWN OF BYALA - OPPORTUNITIES FOR INNOVATION
}

\author{
Yoana Konstantinova
}

D.A.Tsenov Academy of Economics, Svishtov, Bulgaria

e-mail:d010422272@uni-svishtov.bg

\section{Received:08 December 2021 Accepted:29 December 2021 Online Published:30 January 2022}

\begin{abstract}
:
This article aims to examine the opportunities for innovations in the development of cultural tourism in the town of Byala. The study focuses on five cultural heritage sites categorized as cultural values of national significance. They are analyzed according to the following three indicators: cultural and historical significance, accessibility, and current condition. The main problems regarding their potential to attract tourists are outlined. For the purpose of the study, several additional factors are considered. They include implemented marketing strategies, established links with travel intermediaries, accommodation and catering establishments.

The main methods used for obtaining the results include the comparative method and the methods of analysis and synthesis. The official sources of information used for the purpose of this study include documents, official websites, and books.

The results of the study indicate that no marketing strategies have been developed and implemented so far and the aforementioned cultural heritage sites remain unknown to potential visitors. No links have been established with travel intermediaries.

On the basis of the analysis carried out, several innovations have been proposed by the author. Due to its rich history and strategic location, the town of Byala has great potential to become a popular destination for cultural tourism.
\end{abstract}

Keywords: cultural tourism, innovations, cultural heritage, cultural heritage site, cultural value, Byala

JEL classification: O10, Z30, Z31

Citation:

Konstantinova, Y. (2022). Cultural tourism development in the town of Byala - opportunities for innovation. Access to science, business, innovation in digital economy, ACCESS Press, 3(1): 67-80.

https://doi.org/10.46656/access.2022.3.1(6)

\section{INTRODUCTION}

Culture is one of the main motivations for tourists to visit a destination. Cultural tourism accounts for about $40 \%$ of all European tourism (European Commission, 2022). According to the definition by the United Nations World Tourism Organization adopted during the $22^{\text {nd }}$ Session of its General Assembly (UNWTO, 2017), cultural tourism is "a type of tourism activity in which the visitor's essential motivation is to learn, discover, experience and consume the tangible and intangible cultural attractions/products in a tourism destination. These attractions/products relate to a set of distinctive material, intellectual, spiritual and emotional features of a society that encompasses arts and architecture, historical and cultural heritage, culinary heritage, literature, music, creative industries and the living cultures with their lifestyles, value systems, beliefs and traditions". Cultural tourism products represent the market value of cultural tourism. Cultural tourism 
development has been identified as one of the priorities in the National Strategy for Sustainable Development of Tourism in the Republic of Bulgaria for the period 2014-2030. According to W. Munsters and G. Richards (Munsters $\S$ Richards, 2021, p. 19), each cultural tourism product is a combination of a core product and additional product. The core product is the cultural tourism supply (museums, monuments, cultural events, etc.) and the related specific cultural tourist services (information and education). The additional product is "the general tourism product elements and the related tourism services that contribute to the tourist attraction value, but that are not in themselves a reason to visit" (Munsters \& Richards, 2021, p.19-20). It consists of general tourism facilities and services transportation infrastructure.

The term "cultural property" is defined in the 1954 Hague Convention for the Protection of Cultural Property in the Event of Armed Conflict as (Convention for the Protection of Cultural Property in the Event of Armed Conflict with Regulations for the Execution of the Convention 1954) "(a) movable or immovable property of great importance to the cultural heritage of every people, such as monuments of architecture, art or history, whether religious or secular; archaeological sites; groups of buildings which, as a whole, are of historical or artistic interest; works of art; manuscripts, books and other objects of artistic, historical or archaeological interest; as well as scientific collections and important collections of books or archives or of reproductions of the property defined above; (b) buildings whose main and effective purpose is to preserve or exhibit the movable cultural property defined in sub-paragraph (a) such as museums, large libraries and depositories of archives, and refuges intended to shelter, in the event of armed conflict, the movable cultural property defined in sub-paragraph (a);(c) centers containing a large amount of cultural property as defined in sub-paragraphs (a) and (b), to be known as 'centers containing monuments",.

According to the Bulgarian Cultural Heritage Act, "Cultural value" is "a non-tangible or tangible evidence of human presence and activity, natural sight or phenomenon, which is significant for the individual, the community or society as a whole, and has value from a scientific or cultural point of view". A cultural value may also be significant for the Bulgarian Orthodox Church'.

"Cultural heritage" is defined by the United Nations Educational, Scientific and Cultural Organization (UNESCO) as "the legacy of physical artifacts and intangible attributes of a group or society that are inherited from past generations, maintained in the present and bestowed for the benefit of future generations" (Sullivan, 2016).

Cultural heritage is further divided into "intangible" and "tangible". Intangible cultural heritage includes "traditions or living expressions inherited from our ancestors and passed on to our descendants" (What Is Intangible Cultural Heritage?, 2021). Tangible cultural heritage includes "the physical objects and artifacts belonging to a culture" such as historic places, buildings, monuments, etc. According to the Bulgarian Cultural Heritage Act, "Cultural value" is "a non-tangible or tangible evidence of human presence and activity, natural sight or phenomenon, which is significant for the individual, the community or society as a whole, and has

\footnotetext{
${ }^{1}$ https://fr.unesco.org/sites/default/files/bulgaria_culturalheritageact_2009_entof.pdf
} 
value from a scientific or cultural point of view". A cultural value may also be significant for the Bulgarian Orthodox Church².

The word innovation comes from the Latin word 'innovationem' (nominative innovatio) meaning 'to change" or "to renew" . There are many definitions of the term ${ }^{4}$. According to one of them, "an innovation is a new or improved product or process (or combination thereof) that differs significantly from the unit's previous products or processes and that has been made available to potential users (product) or brought into use by the unit (process)" ". According to the Oslo Manual, there are four types of innovation: marketing innovation, process innovation, product innovation, and organizational innovation (OECD Library).

Innovations play a key role in the development of cultural tourism. They are aimed at achieving long-term sustainability and profitability. In the context of cultural tourism, the main challenges include attracting more tourists, and preserving cultural resources.

\section{OPPORTUNITIES FOR TOURISM DEVELOPMENT IN THE TOWN OF BYALA}

\section{A. THE TOWN OF BYALA - MAIN FACTORS FOR TOURISM DEVELOPMENT}

The town of Byala is located in Northern Bulgaria. It is the administrative center of Byala Municipality which is the second largest municipality by population in district of Ruse (Fig. 1).

\section{POPULATION IN RUSE DISTRICT BY MUNICIPALITIES IN 2020}

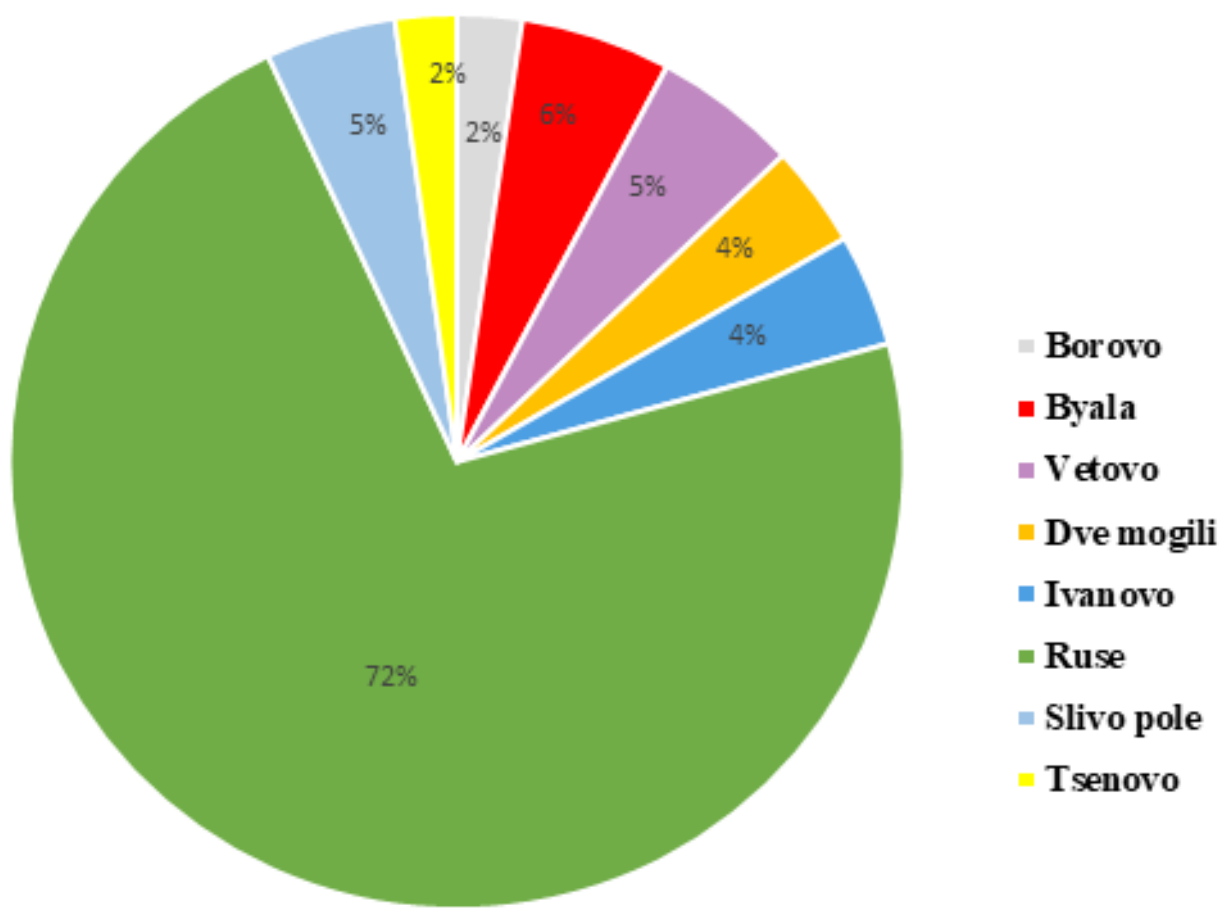

Figure 1. Population in the District of Ruse by Municipalities in 2020

Source: Author's own calculations according to data of the National Statistical Institute

\footnotetext{
${ }^{2}$ https://fr.unesco.org/sites/default/files/bulgaria_culturalheritageact_2009_entof.pdf

${ }^{3} \mathrm{https}: / / \mathrm{www} . e t y m o n l i n e . c o m / s e a r c h ? \mathrm{q}=$ innovation\&ref=searchbar_searchhint

${ }^{4}$ https://torkar.github.io/pdfs/jss-edisonNT13.pdf

${ }^{5}$ https://www.oecd-ilibrary.org
} 
Beside Byala, there are 7 more municipalities included in the district of Ruse (Fig.2). The location of the town of Byala is strategic. The European route E85, which is part of the international E-road network, passes through its territory. The population of the town accounts for $62 \%$ of the total population of Byala Municipality (Fig.3). The number of its inhabitants has been decreasing significantly (Fig 4). The town is easily accessible by road and rail. Its territory of the town has been inhabited since antiquity.

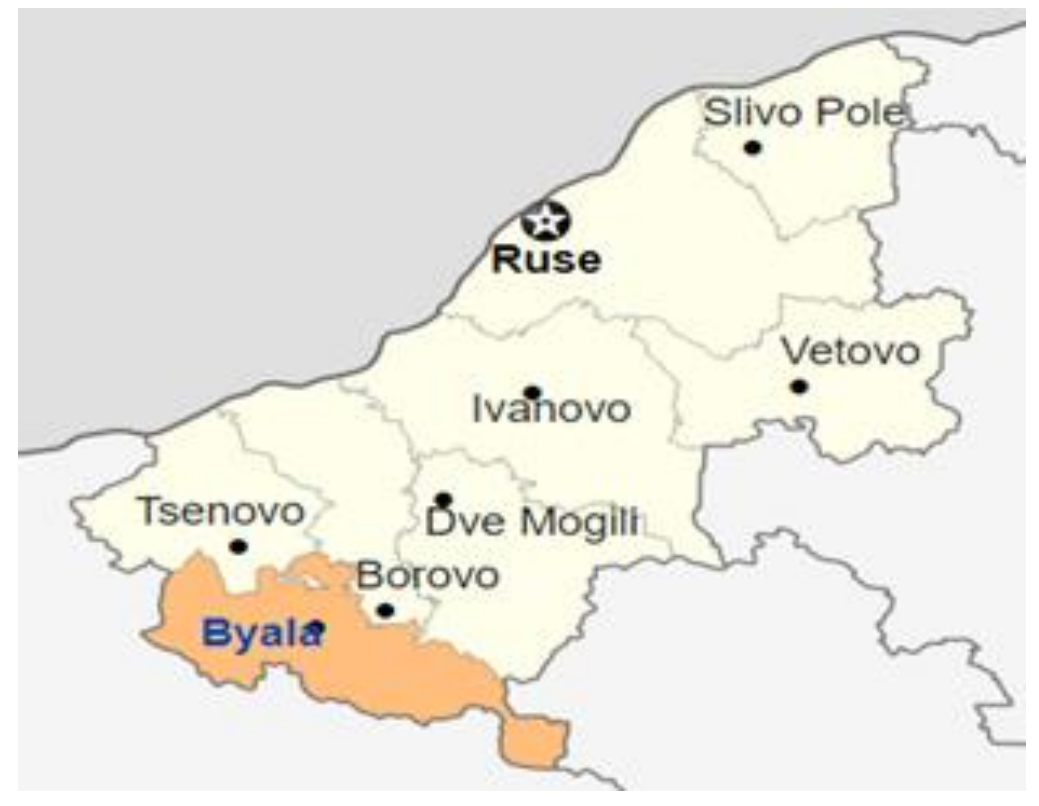

Figure 2. Municipalities in the district of Ruse

Source: https://en.wikipedia.org/wiki/Byala_Municipality,_Ruse_Province

This article aims to examine the opportunities for innovations in the development of cultural tourism in the town of Byala.

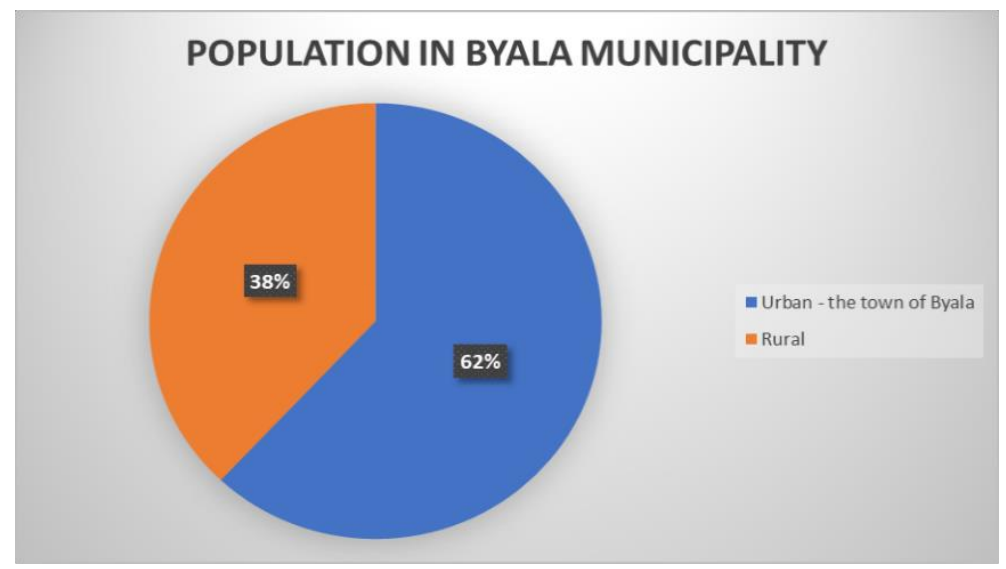

Figure 3. Population in Byala Municipality

Source: The National Statistical Institute 


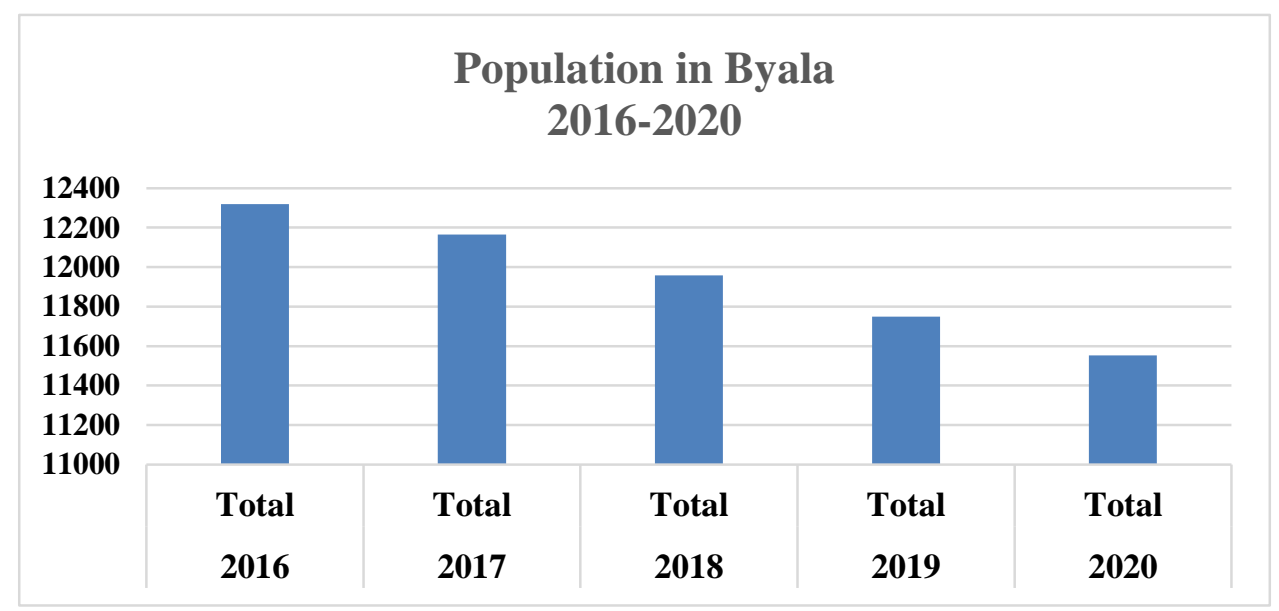

Figure 4. Population in Byala 2016-2020

Source: The National Statistical Institute

The study focuses on five cultural heritage sites categorized as cultural values of national significance. These include Kolyu Ficheto's Bridge over the Yantra River, "St. George" church, the monument of Panayot Volov, Georgi Ikonomov, and Stoyan Angelov, the Liberation War Museum, and the gravestone of Yulia Vrevskaya and Maria Neelova.

\section{B. ACCOMMODATION AND CATERING ESTABLISHMENTS AS AN IMPORTANT FACTOR} CONTRIBUTING TO THE DEVELOPMENT OF TOURISM

There are several accommodation establishments in Byala Municipality. All of them are close to the aforementioned cultural heritage sites. (Table 1).

Table 1. Accommodation establishments in Byala Municipality in 2020

\begin{tabular}{|l|l|l|l|}
\hline \multicolumn{1}{|c|}{ Name } & \multicolumn{1}{|c|}{ Category } & $\begin{array}{c}\text { Number of } \\
\text { stars }\end{array}$ & \multicolumn{1}{c|}{$\begin{array}{c}\text { Number of rooms } \\
\text { and beds }\end{array}$} \\
\hline "Formula 1" & Motel & 1 & 12 rooms; 20 beds \\
\hline "Verona" & Family hotel & 2 & 10 rooms; 22 beds \\
\hline "Odessa" & Family hotel & 1 & 7 rooms; 14 beds \\
\hline "Magnoliya" & Motel & 1 & 8 rooms; 20 beds \\
\hline "Kosharite" & Guest house & 1 & 4 rooms; 8 beds \\
\hline "Mirazh" & Guest rooms & 1 & 4 rooms; 11 beds \\
\hline
\end{tabular}

The restaurant sector contributes significantly to the image of tourist destinations and their cultural heritage sites, respectively (Sparks et al, 2002)

There are 43 catering establishments in Byala Municipality (Table 2). 
Table 2. Catering establishments in Byala Municipality in 2020

\begin{tabular}{|l|c|c|}
\hline \multicolumn{1}{|c|}{ Location } & $\begin{array}{c}\text { Number of catering } \\
\text { establishments }\end{array}$ & Number of seats \\
\hline Byala & 30 & 1867 \\
\hline Bistrentsi & 1 & 20 \\
\hline Bosilkovtsi & 1 & 20 \\
\hline Botrov & 2 & 40 \\
\hline Drianovets & 1 & 20 \\
\hline Koprivets & 3 & 215 \\
\hline Polsko Kosovo & 4 & 145 \\
\hline Peychinovo & 1 & 25 \\
\hline
\end{tabular}

Source: Plan for Integrated Development of Byala Municipality

According to the Plan for Integrated Development of Byala Municipality, the number of overnight stays in the municipality for the period 2017-2019 is 15328 of which 4833 in 2017, 4828 in 2018, and 5667 in 2019. The income from tourist taxes in 2019 is calculated to be BG 3752 .

\section{THE CULTURAL HERITAGE SITES IN BYALA AS A TOOL FOR ATTRACTING TOURISTS}

1. Kolyu Ficheto's Bridge has become a symbol of the town and the municipality of Byala. It is situated about $1 \mathrm{~km}$ from the town of Byala, close to the European route E85, which is part of the international E-road network. The bridge is located near some of the most popular tourist attractions in the region such as the Ivanovo Rock Churches which are included in the UNESCO List, Orlova Chuka cave, the medieval fortified town of Cherven, and the ruins of the Roman and early Byzantine town of Nikopolis ad Istrum.

Kolyu Ficheto's Bridge was built in 1865-1867 by master builder Kolyu Ficheto on the orders of Mithad Pasha, Vali of the Danube Vilayey. Kolyu Ficheto is a Bulgarian builder, architect, and sculptor. AustroHungarian geographer and author of travel notes Felix Kanitz wrote the following about Kolyu Ficheto and the bridge: "This humble man in traditional clothes does not realize that his bridge near Byala is the greatest hydraulic building in the Balkans, excluding Constantinople" (Trankova, 2012).

The bridge is a remarkable achievement of Bulgarian Revival engineering, construction, and architecture. It was declared an architectural monument of art and culture by the National Council for the Protection of Monuments of Culture (Kolyu Ficheto's Bridge over the Yantra River - Byala, n.d.). The bridge is $276 \mathrm{~m}$ long and $9.50 \mathrm{~m}$ wide. It has 14 semicircular arches and 13 pillars. There is a marble slab with an Arabic inscription which is set on one of the pillars in the middle of the bridge. The pillars are decorated with sculptures of symbolic creatures such as swan, griffin, lion, and nymph. In June 1897, several arches in the western part of 
the bridge were destroyed due to a devastating flood. In 1922-1923 the destroyed part of the bridge was restored and reinforced.

\section{The Liberation War Museum}

The exposition reflects events related to the Russo-Turkish Liberation War of 1877-1878. In the yard of the museum, there are original cannons, projectiles, five ten-piece Nobel machine guns, Hertz mines, as well as part of the pontoon bridge on which Russian troops crossed the Danube River. The building is in a typical Bulgarian Revival style. It has 13 rooms.

3. "St George" church was built in 1911. The tower of the church has 4 bells. The largest one weighs 1500 $\mathrm{kg}$.

\section{The gravestone of Yulia Vrevskaya and Maria Neelova}

Yulia Vrevskaya and Maria Neelova were two nurses who worked in one of the field hospitals in Byala during the Russo-Turkish War. Vrevskaya and Neelova got infected with typhus and passed away in early 1878. In 1901, the grave of the nurses was moved to the yard of the Liberation War Museum which is located near the town centre.

\section{The monument of Panayot Volov, Georgi Ikonomov and Stoyan Angelov}

Panayot Volov was one of the leaders and organizers of the Bulgarian April Uprising against the Ottoman Empire in 1876. Together with Georgi Ikonomov, a revolutionary, and Stoyan Angelov, an insurgent, drowned in the Yantra River during their attempt to flee to Romania. They were betrayed to the Ottoman authorities. In 1901 Stoyan Zaimov, Angel Krushkov, and Nikola Obretenov decided to build a monument in their honor.

6. Other cultural heritage sites located in the town of Byala include:

- the Town Clock Tower

- "St. Pantaleon" church

- the Memorial to Nikolay Pirogov

- the Memorial to those killed in the wars in the town of Byala and Ruse Region

- The monument to the Russian officers and soldiers killed in Byala. It is located in Hanishta, one of the districts of the town, near the two bridges over the Yantra River - "The Russian monument"

- The monument of Kolyu Ficheto in the western part of the bridge that was built by him

- Memorials to the volunteers from Byala

- The memorial to the people from Byala and the region who were killed in the wars. It is located in the town center.

- The monument of Diana, the Roman goddess of hunting

\section{METHODS}

The methods used for the purpose of the study include the comparative method and the methods of analysis and synthesis. Comparative analysis is performed with regard to the respective objects of the study. Benchmarking is used for obtaining the results. 
Other methods used for obtaining the results include the collection and organization of information.

The official sources of information used for the purpose of the study include the National Strategy for Sustainable Development of Tourism in the Republic of Bulgaria for the period 2014-2030, the Plan for Integrated Development of the Municipality of Byala for the period 2021-2027, the National Register of Immovable Cultural Heritage, the National Statistical Institute, and the official website of the United Nations World Tourism Organization.

The information used in this study is present in publicly available materials. It includes data collected from websites and books.

\section{RESULTS}

There are five cultural values of national significance on the territory of the district of Ruse (Source: the list of immovable cultural values /ICV/ /monuments of culture/, categorized as "of national significance" on the territory of the district of Ruse, in accordance with the Cultural Heritage Act). All of them are located in the town of Byala. Kolyu Ficheto's bridge is an architectural monument of art and culture.

Kolyu Ficheto's Bridge is currently in poor condition. There are many cracks. The foundations of the bridge are being undermined. The Plan for integrated development of the municipality of Byala for the period 2021-2027 describes a proposed project for the restoration of the bridge and its positioning as a tourist attraction. According to the project, a two-storey building with a modern architectural design is planned to be built close to the bridge (fig.5). The project includes the construction of:

- a restaurant;

- several service rooms;

- a projection hall;

- a souvenir shop.

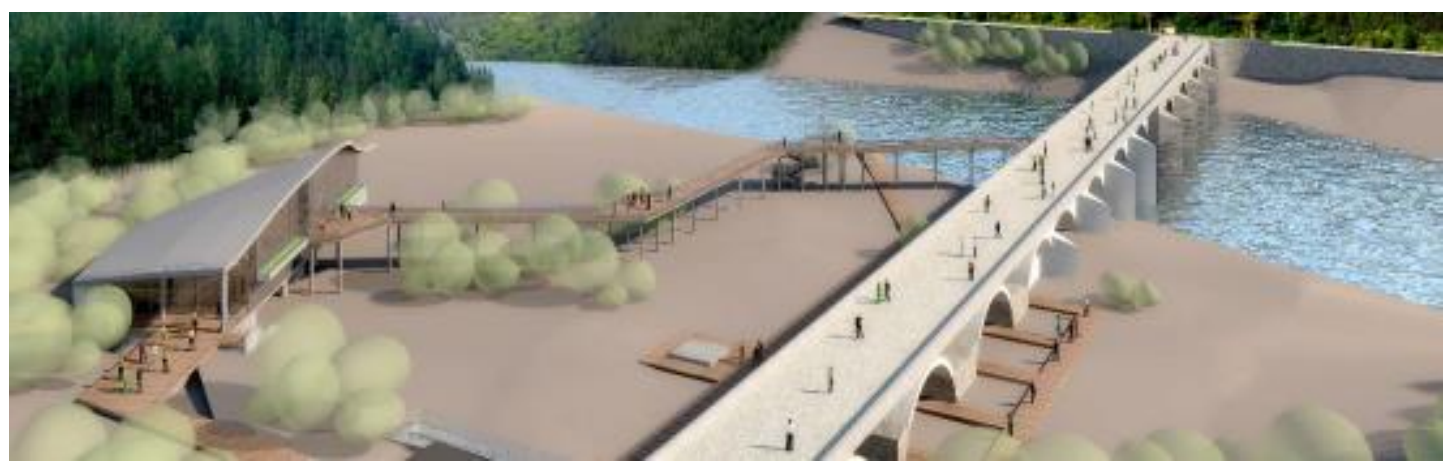

Figure 5. 3D model of Kolyu Ficheto's bridge and the building Source: The Plan for integrated development of the municipality of Byala for the period 2021-2027

Currently, no fees are being collected for the visit of the bridge and no income is being generated. The bridge remains unknown to potential visitors from Bulgaria and abroad. 
The Liberation War Museum in the town of Byala has been declared a cultural value of national significance. The building was erected in the early 19th century. In the early 20th century, it was renovated and turned into a museum. The fence of the museum is made of stone, constructed in the style of a medieval fortress. The museum is located near the town centre and is currently in good condition.

C. "St George" church is currently in good condition. The church is a cultural value of national significance. It is located in the town center and is easily accessible.

D. The gravestone of Yulia Vrevskaya and Maria Neelova is a cultural value of national significance.

The place is easily accessible by road.

E. The monument of Panayot Volov, Georgi Ikonomov and Stoyan Angelov is a cultural value of national significance. The monument is in good condition and easily accessible by road.

Both culture and tourism are essential components of the development of cultural tourism. There are many factors contributing to the development of cultural tourism. Each of them could be an important indicator when analyzing cultural heritage sites and their potential to become popular tourist attractions. The author divides the indicators into three groups (Fig.6). The first group includes three basic indicators, the second group includes the ones related to the promotion of cultural heritage sites, and the third group includes other indicators considered important. The more criteria are fulfilled, the more attractive a cultural heritage site is for tourists. The indicators from the first and the second group are used for the purpose of the study.
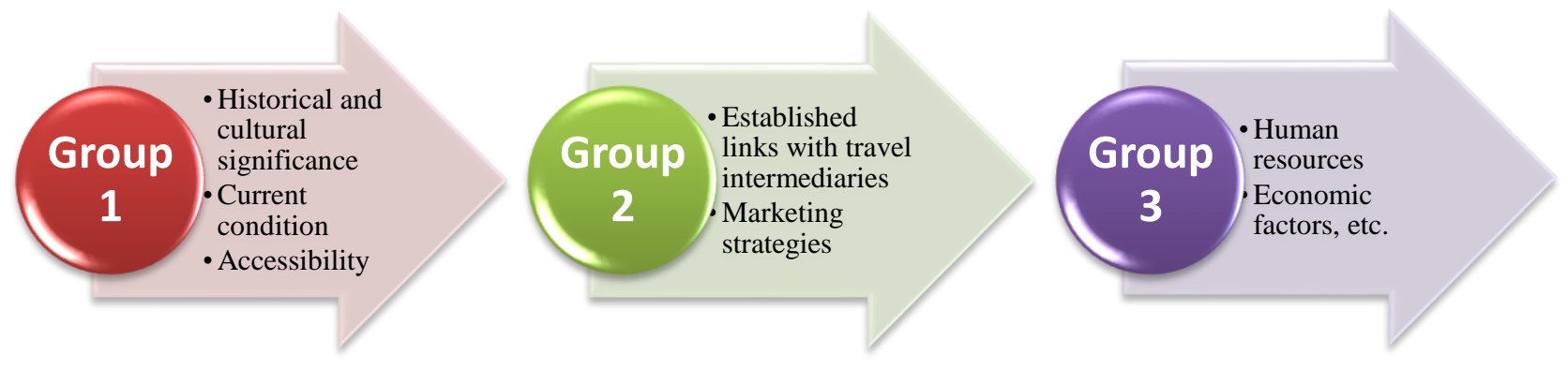

Figure 6. Division of indicators into three groups

In Table 3 a comparative analysis of the cultural heritage sites has been performed in accordance with the author's division of the indicators in group 1 .

The result of the analysis of the cultural heritage sites shows that none of the criteria mentioned in the second group are fulfilled.

The indicators from the third group are subject to further analysis. 
Table 3. Basic indicators, characterizing the cultural heritage sites

\begin{tabular}{|c|c|c|c|}
\hline \multirow[t]{2}{*}{ Name } & \multicolumn{3}{|c|}{ INDICATORS GROUP 1} \\
\hline & $\begin{array}{l}\text { Cultural and } \\
\text { historical significance }\end{array}$ & Accessibility & Current condition \\
\hline Kolyu Ficheto's Bridge & $\begin{array}{l}\text { Cultural value of national } \\
\text { significance. } \\
\text { Architectural monument } \\
\text { of art and culture }\end{array}$ & $\begin{array}{l}\text { Easily accessible by road. } \\
\text { Strategic location, close to the } \\
\text { European route E85 which is } \\
\text { part of the international E-road } \\
\text { network }\end{array}$ & $\begin{array}{l}\text { Currently in bad } \\
\text { condition, } \\
\text { reconstruction }\end{array}$ \\
\hline $\begin{array}{l}\text { The Liberation War } \\
\text { Museum }\end{array}$ & $\begin{array}{l}\text { Cultural value of national } \\
\text { significance }\end{array}$ & $\begin{array}{l}\text { Easily accessible by road. Close } \\
\text { to the town centre; }\end{array}$ & In good condition \\
\hline "St George" church & $\begin{array}{l}\text { Cultural value of national } \\
\text { significance }\end{array}$ & $\begin{array}{l}\text { Easily accessible by road. } \\
\text { Located in the town centre }\end{array}$ & In good condition \\
\hline $\begin{array}{l}\text { The gravestone of } \\
\text { Yulia Vrevskaya and } \\
\text { Maria Neelova }\end{array}$ & $\begin{array}{l}\text { Cultural value of national } \\
\text { significance }\end{array}$ & $\begin{array}{l}\text { Easily accessible by road. Close } \\
\text { to the town centre }\end{array}$ & In good condition \\
\hline $\begin{array}{l}\text { The monument of } \\
\text { Panayot Volov, Georgi } \\
\text { Ikonomov and Stoyan } \\
\text { Angelov }\end{array}$ & $\begin{array}{l}\text { Cultural value of national } \\
\text { significance }\end{array}$ & $\begin{array}{l}\text { Easily accessible by road. } \\
\text { Strategic location, } \\
\text { close to the European route E85 } \\
\text { which is part of the international } \\
\text { E-road network }\end{array}$ & In good condition \\
\hline
\end{tabular}

Source: Systematized by the author

\section{DISCUSSION}

A cultural heritage site should be easily accessible in order to be considered appealing to cultural tourists. All cultural heritage sites in the town of Byala are easily accessible by road.

No links have been established with travel intermediaries such as travel agents and tour operators so far. The total number of tourist agents and tour operators on the territory of the district of Ruse is $57^{6}$. There are no tourist information centers, tourist agents and tour operators located in Byala Municipality (according to the List of Registered Tour Operators and Tour Agents, published on the official website of the Ministry of Economy, Energy and Tourism)

According to the electronic portal of the Ministry of Economy, Energy and Tourism ${ }^{7}$, there are 53 tour operators and tour agents on the territory of the district of Ruse.

\footnotetext{
${ }^{6}$ https://ntr.tourism.government.bg/Registration.nsf/alltato.xsp

${ }^{7}$ http://tourism.egov.bg/registers/TORegister.aspx?AspxAutoDetectCookieSupport=1
} 
There is no official tourism website of the destination. The names of the cultural heritage sites were entered by the author into two of the most popular search engines - Google and Yahoo. The results showed that there is little information available online.

\section{GENERAL CONCLUSIONS:}

- No marketing strategies have been developed and implemented so far. As a result, the cultural heritage sites in the town of Byala remain unpopular;

- In terms of signage and parking facilities, there are not enough tourist signposts and parking places in the town;

- No links with tour operators and tour agents have been established so far

- There is no official tourist website of the tourist destination

- There is no information regarding the cultural heritage sites on social media

- There is not enough information regarding the aforementioned cultural heritage sites on the official website of Byala Municipality

The town of Byala has great potential to become a popular tourist destination, but there is a wide range of problems that require timely and adequate measures.

The measures should be taken in collaboration with the following shareholders:

- The Government (the Ministry of Economy, the Ministry of Tourism)

- The local government (the municipality, the municipal council)

- The regional administration

- The regional and local organizations

- NGOs

- Professional organizations and associations

- SMEs

On the basis of the analysis carried out, several innovations have been proposed by the author. The measures include:

$>$ creating cultural and natural corridors along the Yantra River

$>$ restoration of cultural heritage, if necessary;

$>$ reducing the negative impact of tourism activities such as environmental pollution, destruction of cultural resources, etc.

$>$ establishing links with travel intermediaries such as tour operators and travel agents;

$>$ launching an image campaign;

$>$ setting up partnerships involving all shareholders (government, associations, universities, residents, entrepreneurs, etc.);

$>$ designing an official tourism website of the destination;

$>$ promoting the destination on social media; 
using Big Data in processing information;

using virtual and augmented reality

\section{CONCLUSION}

The analysis performed in the article shows that the main reason for the unpopularity of the cultural heritage sites in the town is the lack of marketing strategies. No links have been established with tour operators and travel agents so far. The strategic approach should be focused mainly on building the desired image of the destination and its cultural heritage respectively. Due to its strategic location and cultural value, the town of Byala has the potential to become a popular tourist destination.

The results from the study could be used for different purposes such as: creating and maintaining a database of cultural heritage in Bulgaria, incorporating strategies for cultural tourism development in the region, performing analysis, and conducting further research on cultural heritage sites in the town of Byala.

\section{Conflict of interests}

The authors declare no conflict of interest.

\section{References}

Architectural heritage of grand master Kolyo Ficheto. (2018). History and Religion. Retrieved January 17, 2022, from https://bnr.bg/en/post/100977787/architectural-heritage-of-grand-master-kolyo-ficheto

Beverley Sparks, Karen Wildman, John Bowen. (2015). Research Report. https://sustain.pata.org/wpcontent/uploads/2015/02/ConsumerInterviews_v5.pdf

Bozhinova, M., Georgieva, K. Organizations for tourism region management in Bulgaria - trends and challenges. Trakia journal of sciences: Series Social sciences, 2019, бp.1, c.365-370, Trakia University, ISSN 1313-7069

Byala keeps the memory of Yulia Vrevska (2013, March 3) [Byala pazi spomena za Yulia Vrevska. (2013, Mart 3)]. Bulevard.bg. Retrieved January 19, 2022, from https://bulevard.bg/news/byala-pazi-spomena-za-yuliya-vrevska$\underline{8470 . \mathrm{html}}$

Benchmarking // A dictionary of business. - Oxford: Oxford University Press, 2002. - P. 112-113

Camp R.C. (1989) Benchmarking. The Search for Indystry Best Practices That Lead to Superior Performance, ASQC Industry Press, Milwaukee, Wisconsin.

Camp R. A. (1993) A bible for benchmarking, by Xerox / R. Camp// Financial Executive.- Vol. 9, No4. - P. 23-29.

Chernyshova, O. (2016). The Female Face of War. The Sisters of mercy during the Russo-Ottoman War of 1877 - 1878 , 3 (XXV), 42-50. Balcanistic Forum. Retrieved January 07, from http://memoryrow.weebly. com/uploads/1/3/8/5/13852932/angelova_kelbecheva_-_gender_and_war_memory_1877-78.pdf

Convention for the Protection of Cultural Property in the Event of Armed Conflict with Regulations for the Execution of the Convention. (n.d.). United Nations Educational, Scientific and Cultural Organization. Retrieved January 17, 2022, from http://portal.unesco.org/en/ev.php-

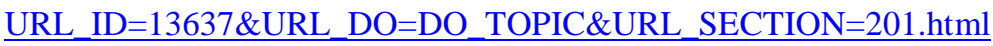

European Comission. (n.d.). Internal Market, Industry, Entrepreneurship and SMEs. Retrieved January 07, 2022, from https://ec.europa.eu/growth/sectors/tourism/offer/cultural_en

European route E85. (2022, January 17). In Wikipedia. https://en.wikipedia.org/wiki/European_route E85

Evans J.R., Lindsay W.M. (2002) The management and control of quality. -5 ed. -Ohio: South Western. -838 p.10

Grayson C. J., O’Dell, C. (1998). If only we know what we know: identification and transfer of internal best practices. 
California Management Review. - 1998. - Vol. 40. - P. 154-174.

History and Culture (n.d.) Byala Municipality. Retrieved from https://byala.bg/bg/1555930017.html

Historical Museum - Byala, Ruse province. (n.d.). EN [Institut za prilozhna muzeologiya]. Retrieved January 07, 2022, from http://www.museology.bg/en/museums/i132/historical-museum-byala.html\#.YdrpOTNBzIU

Hristov , H . (2006). Byala. Short History, pp.10-58, Vesta Pres:Byala // Hristov. H.(2006). Byala. Kratka istoriya, 1058.

Kolarov, I. (1996). Paths to Byala // Kolarov, I. (1996). Pateki kam Byala, pp.46-53.

Kolyu Ficheto's Bridge over the Yantra River - Byala. (n.d.). Bulgaria. A Discovery to Share. Retrieved January 07, 2022, from https://bulgariatravel.org/kolyu-fichetos-bridge-over-the-yantra-river-byala/

List of immovable cultural values /ICV/ /monuments of culture/, categorized as "of national significance" on the territory of the district of Ruse, according to the Cultural Heritage Act., http://ninkn.bg/documents/download/51

List of Registered Tour Operators and Tour Agents http://tourism.egov.bg/registers/TORegister.aspx? $\underline{\text { AspxAutoDetectCookieSupport }=1}$

List of Registered Tourist Associations. https://ntr.tourism.government.bg/TUnionsV2.nsf/tunion.xsp

Ministry of Economy. (2014). Strategy for Sustainable Development of Tourism in Bulgaria 2014-2030 //Strategiya za ustoychivo razvitie na turizma v Bulgaria 2014-2030 [2014-2030] https:/www.tourism.government.bg/sites/ tourism.government.bg/files/uploads/strategy-policy/strategy_2014-2030_13_05_2014-sled_ms_26_05_2014.pdf

Municipality of Byala. (2020). [Plan za integrirano razvitie na obshtina Byala, oblast Ruse za period 2021-2027g.] https://strategy.bg/FileHandler.ashx?fileId=27254

Municipality of Byala. (2020). Plan for Integrated Development of Byala Municipality, Ruse Region for the period 20212027 [Plan za integrirano razvitie na obshtina Byala, oblast Ruse za period 2021-2027g.] https://strategy.bg/FileHandler.ashx?fileId=27254

Municipality of Byala. (2021, February 24). Mowlem.Eu. Retrieved January 07, 2022, from https://mowlem.eu/municipality-of-byala/

Munsters, W., Richards, G. (2021). The Study of Cultural Tourism in Ten Models. 20-21 https://www.researchgate.net/publication/351746481_The_Study_of_Cultural_Tourism_in_Ten_Models__Wil_Munsters

OECD library. The Innovation Imperative Contributing to Productivity, Growth and Well-Being. https://read.oecdilibrary.org/science-and-technology/the-innovation-imperative_9789264239814-en\#page4

Public Register of the National Institute for Immovable Cultural Heritage http://ninkn.bg/documents/download/51

Ruseva, D. (2002). Byala. An Attempt at an Ethnographic Essay //Ruseva, D.(2002). Byala. Opit za etnografski ocherk, 7-9.

Sardak, S. E., Krupskyi, O. P., Dzhyndzhoian, V., Sardak, M., \& Naboka, Y. (2020). Development of historical and cultural tourist destinations. Journal of Geology, Geography and Geoecology, 29(2), $406-414$. https://doi.org/10.15421/112036

Society for Human Resource Management // Glossary, 2005.

Trankova, D. (2012). Major landmark just off international highway near Ruse. Retrieved from January 07 , https://vagabond.bg/bridge-byala-1556

United Nations Educational, Scientific and Cultural Organization. (n.d.). What is Intangible Cultural Heritage? Retrieved January 02, 2022, from https://repository.law.uic.edu/cgi/viewcontent.cgi?article=1392\&context=ripl; https://ich.unesco.org/en/what-is-intangible-heritage-00003

UNWTO. (n.d.). Tourism and Culture. Retrieved January 07, 2022, from https://www.unwto.org/tourism-and-culture

Yasin M. M. (2002) The theory and practice of benchmarking: then and now. Benchmarking: an International Journal. - Vol. 9, No3. - P. 217-243, c.220

http://100nto.org/objects-po-oblasti/rusenska-oblast/50g-biala-muzej.html

http://www.ruskipametnici.com/?action=news\&id=7

$\underline{\text { https://artcenterbyala.bg/ }}$

https://ntr.tourism.government.bg/Registration.nsf/detail.xsp?id=ECDBB1F57BD2F0ACC22576C1002DC9FE 
About the author:

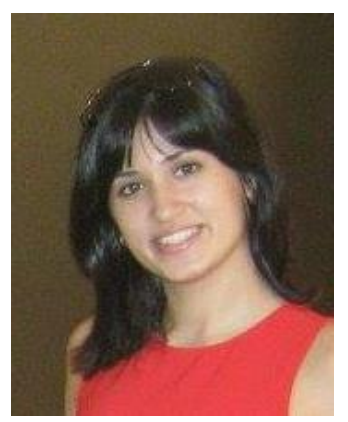

\section{Yoana KONSTANTINOVA}

PhD student, Department of Tourism Economics and Management, Faculty of Industry and Commerce, D.A.Tsenov Academy of Economics, Svishtov, Bulgaria Senior Data Analyst, A Data Pro Ltd: Sofia, Bulgaria

Scientific interests: innovation activities, cultural tourism, innovations, cultural heritage, cultural heritage site, cultural property.

ORCID ID: https://orcid.org/0000-0002-6060-6288

Copyright (C) 2020 by author(s) and ACCESS Publishing Press This work is licensed under the Creative Commons Attribution International License (CC BY) 


\title{
Monograph Review \\ EFFICIENCY ASSESSMENT OF COMMERCIAL BANKS IN BULGARIA
}

\section{Monograph author: Sergey Rumyanov Radukanov}

\author{
ISBN 978-619-91511-5-0, E-book \\ DOI: 10.46656/book.2021.Radukanov \\ Publisher: ACCESS Press Publishing House. Country: Bulgaria. \\ Language: Bulgarian. Pages: 160.
}

Keywords: commercial banks, efficiency, valuation, finance, Bulgaria. JEL classification: G21, J54, E50

\section{Received: 08 December 2021; Online Published: 30 January 2022}

The monograph presented for publishing, authored by Sergey Rumyanov Radukanov is a serious theoretical and applied development, dedicated to an indisputably current topic, concerning a real, important and pressing economic problem: the problem of the efficiency of banks in Bulgaria, which has been barely developed by the specialized literature in Bulgaria particularly, on a micro-level (i.e. specific institutions' level).

The studied topic has many aspects and requires raising a wide range of questions, concerning various sides of the banking activity.

Originality of studying these problems by the present monograph consists in combination of the theoretical point-of-view and concepts with the practical questions of the efficiency of banks in Bulgaria.

The subject of the study focuses on the specifics of its research and assessment.

The main goal of the monograph is to uncover the opportunities for assessment of the efficiency of banks on the basis of official public information.

The monograph „Efficiency assessment of commercial banks in Bulgaria” is a unique and creative achievement, which renders its considerable effect upon the state of the knowledge, application of the innovative analytical methods, based on modern mathematical instruments and guidelines for further research when assessing the efficiency of banks on the basis of official public information.

The monograph developed is structurally sound, has the required logical consistency when exploring the respective questions, and the underlying clever combination of theoretical and practical and applied aspects of the studied problems is showing through.

The tasks set by the author were clearly and definitely formulated: 
- Outlining of the theoretical viewpoints and the evolution of opinions on the efficiency as economic category;

- Presentation of certain debatable questions, concerning bank efficiency;

- Argumentation of the input parameters (criteria), upon which the assessment of the efficiency of the bank as a specific enterprise is based;

- Argumentation of a system of parameters for external analysis of the efficiency;

- Building up of a model for assessment of the bank efficiency;

- Empirical testing of the model developed on the basis of the officially published and publicly accessible information.

The beginning of the presentation includes the theoretical foundations of the bank efficiency (Chapter One). Proceeding from this basis is the model for its assessment proposed by the author (Chapter Two). The research ends with an empirical testing of the problem, which permits drawing of the respective summarizations and conclusions (Chapter Three).

The author is very well acquainted with the condition and the degree of elaboration of the problem in the specialized economic literature, as well as with the practical achievements in the field studied by him. He bases his development on a rich and diverse range of literary sources. The monograph logically structured in three chapters comprises a list of references, including 147 titles. Literary sources have been used in good faith and have been accurately quoted. The author demonstrates his abilities to systematize and critically rationalize the existing scientific theses or practical problems and using this basis to defend his opinion in a well substantiated manner.

An agreeable feature is the striving of the author where possible or required, to intensify the debatable nature of the development. Regarding some questions he presents different opinions and viewpoints of certain authors, a feature imparting a better marked explorative nature to his work.

The monograph is well shaped in stylistic aspect. The text of the presentation is clear, and the style - compact, accurate and grammatically sound. Thus, the results from the research are presented logically and intelligibly.

The monograph is properly structured from the point-of-view of the methodology, using modern mathematical instruments, the results have been discussed and analysed to a high degree of scientific competence. The research presents an innovative problem, which certainly provides a quite valuable view upon the questions, related to the efficiency assessment of banks in Bulgaria.

Systematization and summary performed of the views of the authors working on the problems of bank efficiency can be positively evaluated in terms of the advantages, disadvantages and opportunities for application of various approaches and models for its assessment. The specific features and characteristic specifics of the efficiency of the commercial banks are outlined on the basis of the comparative analysis done. 
A very good mark deserves the original approach in the justification of criteria for assessment of bank efficiency. It is based on the concept of the bank as specific enterprise, regarded as a combination of three inter-related units: 1) provision of the necessary resources for implementing its activity (input); 2) actual production and 3) marketing of the products created (output). This substantiates the three points-of-view, on the basis of which the bank efficiency is analysed - resource efficiency, cost efficiency and market efficiency.

The author presents his own model for assessment of the bank efficiency through using of official public information. His deduction is based on the ,analysis-synthesis” dependency. The model is based on a system of suitably selected indicators, having the required information significance. Initially, every individual efficiency criterion is subjected to quantity analysis using these indicators. Then, using the synthesis method, summarizing evaluation of its level according to the respective criteria is given by means of introduction of specific measuring indicators, called by the author ,index of resource efficiency”, ,index of cost efficiency” and ,index of market efficiency”. These three indexes are synthesized in a final assessment, which finds its quantity expression in the ,integral index of efficiency" proposed by him.

The striving of the author to construct its own development upon the research of a broad base of real data is not to be left without mention. To this end, he performs testing of the presented model for external analysis of the bank efficiency, which proves its practical applicability. The research is performed using a broad empirical material from the operation of twenty-four commercial banks in Bulgaria for a period of seven consecutive years. This imparts a strong practical orientation to the monograph.

The monograph „Efficiency assessment of the commercial banks in Bulgaria” is useful for scientific researchers, doctoral students and students in the field of efficiency assessment of banks in Bulgaria, as well as for broad range of people interested in the different sides of banking activity.

\section{REVIEWER:}

\section{Nguyen Van TRU}

Doctor of Economic,

Information business software consultancy (IBC), Singapore

ORCID ID: https://orcid.org/0000-0002-9218-0015

e-mail: ph_d_tru@yahoo.com 


\section{GUIDELINES FOR AUTHORS}

The submission template must be used in a mandatory manner. This journal register in the submission metadata the ORCID iD from authors.

There is no charge of any amount, either in the submission or publication of articles. Editorial team don't receive any fee. In order to maintain this collaborative activity free of charge, we place the target 120 days from the time between the reception and the publication of the articles. For this we adopted the system of continuous flow of publishing with closing of the editions in the months of May, September and January.

\section{Contribution to definition of authorship}

The recognition of authorship is based on a substantial contribution, related to the following aspects: (i) designing and delineating the study, analysis and interpretation of the data; (ii) writing or critical review relevant to the intellectual content of the manuscript; (iii) final approval of the version to be published; and (iv) responsibility for all aspects of the work, including ensuring its accuracy and integrity. All those designated as authors must meet the four criteria for authorship, and all those who meet the four criteria should be identified as authors.

At the submission checklist, is required that everyone's participation in the preparation of the manuscript and publicly assume responsibility for its content. At the end of the text of the manuscript, a paragraph should be included with the information on the contribution of each author to its elaboration.

Throughout the text, the international system of units (IS) should be used to indicate measures. The article should have the following structure:
a) Introduction;
b) Materials and Methods;
c) Results and Discussion;
d) Conclusion or Final Considerations;
e) References.

Other sections and subsections are accepted, such as the Bibliographic Review, however, the above sections are mandatory. The availability of a template for submission aims to standardize the submission format text of the journal, reducing the publishing period, and making possible the scheduled periodicity. The list of references should be presented at the end of the text, in a specific section. Do not use footnotes!

\section{General requirements for submission formatting}

The language of the article: English.

The article should be prepared and submitted of the journal in word processing program Microsoft Office Word 2003, in ".doc" format, with tables and figures included in the body of the text.

Section headings should be set in bold.

\section{METADATA}

- the author's name, surname (it is obligatory to give the author's name and surname in English according to passport data or any other IDs);

- the author's information (place of work or study, city);

- the title of the article;

- the abstract;

- $\quad$ key words (should not duplicate words from the title of the article); 
- JEL Classification;

- e-mail;

- Identifier ORCID;

- references.

\section{REQUIREMENTS FOR THE TEXT FORMATTING}

Requirements for the structure of the article (elements with text highlighting):

- general problem statement and its connection with main scientific and practical tasks (Introduction);

- analysis of recent researches and publications, which contain background for solution of the given problem and which the author relies on (Analysis of recent researches and publications);

- highlighting of previously unsettled problem constituent that is a part of the main problem, which the article is dedicated to (Previously unsettled problem constituent);

- formulation of the purpose of the article (Main purpose of the article);

- presentation of the main research material with full argumentation of received scientific results (Results and discussions);

- conclusions of the given research and perspectives for further researches in the given direction (Conclusions and further researches directions);

- References;

\section{Requirements for the article formatting:}

- the length of the article is from 10 to 15 pages (8000 words including spaces, but excluding an abstract and references);

- page format - A4 format ( $210 \times 297 \mathrm{~mm})$ page;

- page guidelines: top $-25 \mathrm{~mm}$, bottom $-25 \mathrm{~mm}$, left and right $-20 \mathrm{~mm}$.

- Alignment Justify, Line Spacing Single, Paragraph Before 0 pt, After 0 pt, Indentation Right/Left 0 pt.

- Do not use the numbering of pages.

- the article font guidelines: font size - 11-point, font type - Times New Roman, 1,5 line spacing.

\section{Requirements for formatting of the article structural elements:}

- JEL Classification (without paragraph indent, semi-bold, centered-alignment): font size - 10-point, font type - Times New Roman;

- the author's name and surname (one line space, without paragraph indent, semi-bold, centered-alignment): font size - 12-point, font type - Times New Roman;

- job of author (without paragraph indent, in italics, centered-alignment): font size - 10point, font type - Times New Roman, line spacing - 1,5;

- e-mail (without paragraph indent, in italics, centered-alignment): font size - 10-point, font type - Times New Roman;

- the title of the article (one line space, capital letters, without paragraph indent, semibold, centered-alignment): font size - 14-point, font type - Times New Roman, line spacing - 1 ;

- the abstract and key words (one line space, in italics, justified-alignment): font size 10-point, font type - Times New Roman, line spacing - 1, paragraph indent $-1 \mathrm{~cm}$;

- the text of the article (one line space, justified-alignment): font size - 11-point, font type - Times New Roman, line spacing - 1,5;

\footnotetext{
${ }^{*}$ Exceptionally, a smaller volume is allowed for doctoral students, but at least 8 pages
} 
- references: font size - 10-point, font type - Times New Roman, line spacing - 1; Paragraph spacing: before $5 \mathrm{pt}$, after $5 \mathrm{pt}$;

- identifier ORCID - end of paper (in about the authors), without paragraph indent, leftalignment: font size - 10-point, font type - Times New Roman;

- Author Photo - end of paper (JPG/JPEG format with resolution not less than $300 \mathrm{dpi}$ )

Requirements for formatting the abstract and the author's resume in English (Abstract):

Abstract should be not less than 250 words (not less than 2500 characters), arranged in one column 10 pt, font type - Times New Roman; line spacing - 1 .

Background of the research should be explained in few sentences.

Objectives: Objectives of the paper should be clearly stated in 1-2 sentences. Methods/Approach: Methods used in the paper should be explained in 1-2 sentences. Results: Results of the research should be presented in 1-2 sentences.

Conclusions: Main conclusions should be debriefed in 1-2 sentences.

\section{Requirements for formatting the references (References):}

- REFERENCES are formatting according to international bibliographical standard APA-2010 style in accordance with the specimen and requirements set on the website of the Journal.

- References should include not less than 20 sources, covering important previous works realised in the given area of interest on an international scale. References covered by major citation databases are preferred (Scopus, Web of Science).

- The reference be listed alphabetically and names of all authors should be given. Do NOT use "et al." in the list of references!

- The titles of Cirilic periodicals (journals, collections and others) are given by transliteration, and they are given in parenthesis in English;

- with obligatory citations in the text of the article, which are given in brackets in the text (alphabetically) and they appear in an order of citation or reference;

- references for the personal author's works or articles (self-citation) should not exceed more than $10 \%$ from the general number of sources.

\section{Requirements for drawing tables, pictures and formulas:}

- tables should have a serial number and a title in the middle (Table 1. Title): font size 10, interline spacing - 1, font type - Times New Roman;

- text in table: font size - 9, font type - Time New Roman; interline spacing - 1;

- pictures/ drawings must have a serial number and a name in the middle (Figure 1. Title): font size - 10, interline interval - 1, font type - Times New Roman;

- drawings are made in graphic editors, compatible with Word in the format JPG with a resolution of not less than $300 \mathrm{dpi}$;

- mathematical formulas are provided using the built-in Microsoft Equation formula editor;

- Equations and formulas are arranged in the center of the line, the number of the formula (in round brackets, on the right-hand side of the page, separated by blank lines): font size - 10, interline spacing - 1, font type - Times New Roman.

\section{Final provisions}

At the end of data on affiliation of authors of the manuscript author must specify his/her ORCID ID number (for each of the authors ORCID personal number needed) to allow the readers of this article refer to authors' publications in other journals. 


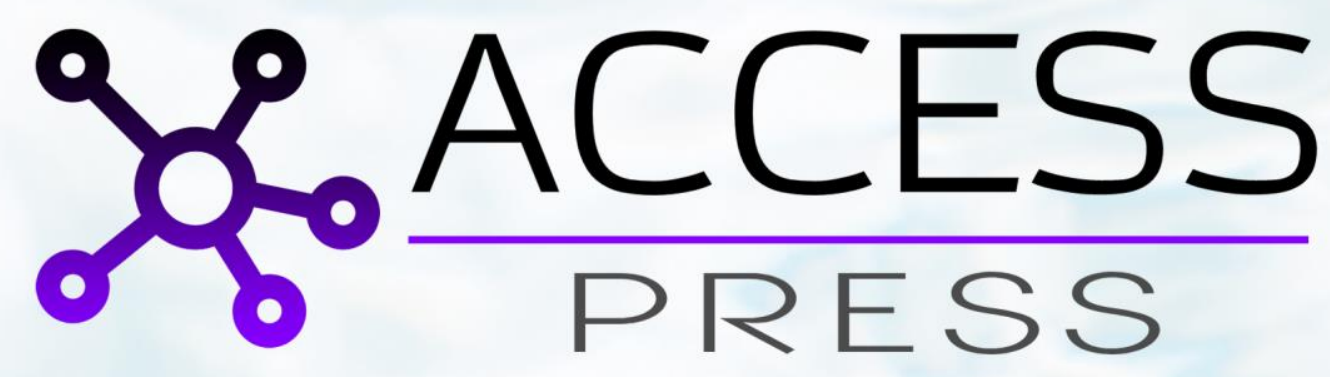

https://access-bg.org

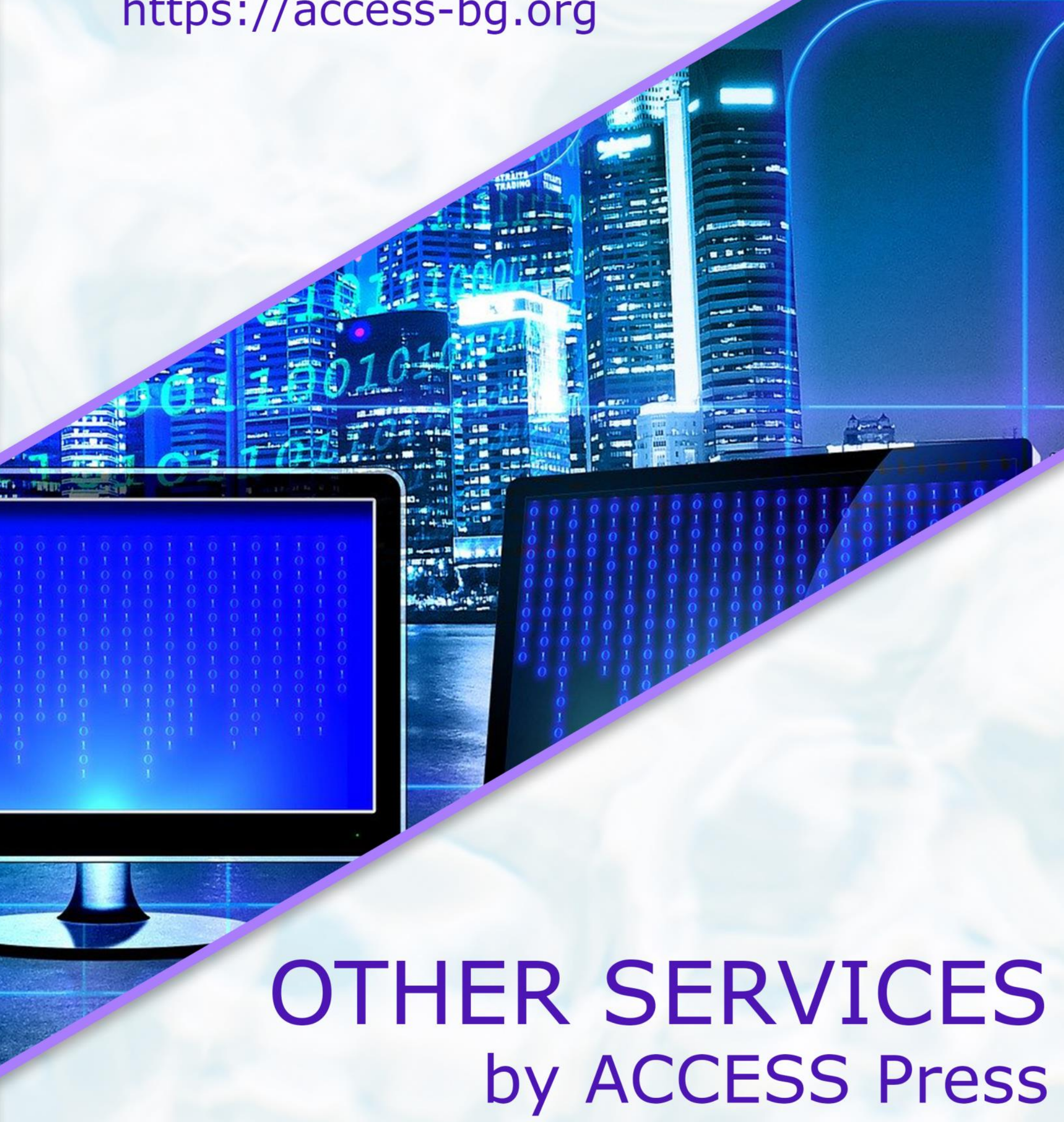




\section{E-BOOKS PUBLISHING}

ACCESS Press aims to meet public needs acting in the areas of education, life-long learning,

training, scientific research, organizing of scientific, cultural and other events.

ACCESS Press has a team with well-established experts with extensive experience in wide range of academic fields of journals, collections and books. In the Reviewer board members are scientists and experts from the countries of Europe, Russia, CIS. This provides an international expert evaluation of

the incoming scientific materials.

\section{Additional services}

ACCESS Press publishes conference abstracts and proceedings, scientific works, yearbooks, monographs, collective monograph series, journals and other literature resources, and management of scientific data sets.

Our team prepares and publishes monographs, scientific and reference literature, PhD and doctoral thesis and dissertations, conference proceedings, monographs in all languages.

We check the text for uniqueness / plagiarism as well as, if necessary, we edit and format the publication.

Publication of various academic and educational literatures enables us to develop and offer our authors european publications with foreign output data with international number ISBN/ ISSN.

We carry out the assessment of all the received articles and books quickly and we can offer optimum terms of cooperation.

When visiting Our E-books section website, you can read electronic books free of charge.

\section{SERVICES}

- Uniqueness verification (plagiarism)

- Article proofreading and editing

- Editing and formatting

- APA style

- Profile registration in ORCID, PUBLONS, Google Scholar, ResearchGate

- Increase of H-index/Work with indexing

- Assign DOIs

- Advertising

\section{Additional services}

- Positioning in a format for e-books (epub, etc.)

- DOI (Digital Object Identifier) assignation. DOI facilitates the process of search, citing and localization of scientific work.

- Inclusion of your monograph into RSCI database Elibrary.ru

- Publication with all metadata - annotation, key words, list of cited references, which will significantly increase author's rating 


\section{WHAT WE PUBLISH}

The wide range of services, we provide, allows us to guarantee a scientist a successful publication indexed in the largest scientific databases.

If you have a ready-made text of a monograph or other scientific publication and you want to publish it, you can take the opportunity of receiving the most qualitative result for the given price.

Your proposal will be evaluated by the Editor(s) and/or an external reviewer who is an expert in the fields covered. If accepted, the final manuscript also needs the approval from the Editor(s) before it is published, to ensure the quality of each book. The cost of services is calculated individually, and there is a fee for the provision of correct editing of materials for promotion in scientific journals, including consulting. The final cost of services varies according to the volume of work and urgency.

Order the service by contacting us on the website or e-mail.

\section{Advertising services}

You can contact the Editor-in-Chief for more detailed information about the financial terms of the advertising in the journal.

We invite scientists, researchers and practitioners to cooperate!

\section{Why electronic format?}

You have the foreign publication in the shortest terms, minimum term is 1 day. You have full legal rights on the intellectual property even if it is an electronic version

You receive the electronic version of your book that has absolutely the same legal properties as a printed version. The electronic version already has all necessary requisites: Bulgarian ISBN and all output data according to the international standards

Moreover, of course, the important parameter is the cost. We offer services of the European quality at the price almost coinciding with the prices in many other countries. Therefore, an electronic format of publication is an excellent option for the favorable and quick publication 


\section{PROCEEDINGS AND CONFERENCES}

ACCESS Press publishes proceedings in all major disciplines. We offer conference, symposium and workshop organizers a unique service which is not only fast and personalized, but also ensures maximum visibility for their conference and workshop proceedings.

All proceedings on the ACCESS Press platform are open access and hence freely accessible for all to read.

Where applicable, we take care that these proceedings are submitted to relevant indexation databases.

ACCESS Press adheres to the ethical frameworks and guidelines of the Committee on Publication Ethics (COPE), including the COPE Core Practices and the Principles of Transparency and Best

Practice in Scholarly Publishing

\section{Included in ACCESS Press proceedings service package}

Creation of a full-fledged web site dedicated to your conference with its own URL, including search engine, table of contents, conference details, etc.

Professional hosting service, guaranteeing 24-hour access and fast response times

Comprehensive similarity checking and plagiarism detection for all articles to be published in a proceedings

Personalized, high-quality assistance for preparing your conference and proceedings

Provision of clear instructions for authors and editors, as well as style sheets, for Word

Fast and high-quality communication with a dedicated Access Press staff member in either English,or Russian

Articles can be of any length with no restrictions on the use of colours and the possibility to add multi-media elements

Fast publication of your proceedings in less than 2 weeks

Registration of an ISBN for your proceedings publication

Inclusion in major search engines, such as Google and Google Scholar

Registration of a unique online reference (DOI) for all articles at CrossRef

Submission to relevant indexation databases 


\section{ONLINE PLATFORM FOR ELECTRONIC JOURNALS}

As ACCESS Press understands the importance of core principles of scholarly communication, the editors of journals strive to organise peer review process within 20 days, and publishing house puts effort in publishing articles usually within 2-4 weeks after acceptance.

All journals on the ACCESS Press platform follow the highest international standards on publishing ethics as described in the ethical frameworks and guidelines of the Committee on Publication Ethics (COPE). ACCESS Press is a strong advocate of integrity in science and adheres

to these guidelines in full. Moreover, we are a strong supporter of the principles of openness, transparency and reproducibility in research and an organizational signatory of the Transparency and Openness Promotion (TOP) guidelines issued by the Center for Open Science.

- Publications are reckoned by the Higher Attestation Commission as a publication in a foreign publishing house.

- European publication with foreign output data with international number ISSN.

- Prompt e-mailing of a journal's electronic version to authors.

- Every journal gets its own space on the web, and still present in the search results for the whole platform.

- Journals are published in open access mode on the publishing house site access-bg.org

We follow strict guidelines for authors and our eminent editorial board members are also dedicated to build a framework that is based on the ethics and virtues of publication. Access Press safeguards that each article is peer-reviewed and goes through a strict screening process before being published.

Detailed information about each journal can be found in their homepages.

ACCESS publishes academic journals that belong to universities, research institutes, academies of sciences, learned societies and other organizations. We can publish them both in the Open Access and in traditional (paid access) models.

We currently publish journals in the English language, but content in other languages will be considered.

We have a special offer for universities and other organizations to publish their English language journals, books and other publications. 
ACCESS Press has a special offer for universities and other organizations that are seeking a partner to publish all or some of their English language journals, books and other publications. This applies to new publications and to previously published books and previous journal volumes. We publish monographs, textbooks, edited volumes, and other categories.

The university can decide if a given journal or book is published using the Open Access or paid access model. All books and journal articles bear both the university and ACCESS logos.

ACCESS Press will design, produce and manage the website of this publishing house. The role of the university is to select and channel books and book proposals for this publishing cooperation, as well as to promote this publishing opportunity to its faculty.

The university can decide which package of services applies to each journal and book. Such packages are described in the pages for journals and books. If the value of the contract exceeds an agreed amount, the university can enjoy discounts up to $60 \%$ on standard fees.

Please contact us to discuss the terms of the ACCESS Publishing House offer.

Recently, the interest of the scientific community in the scientometric indicators impact factor, IF and impact rank, SJR, which reflect the level of citation of articles published in various journals, is increased. Inclusion of scientific journals in global indexed systems for citations Scopus and Web of Science requires the editors and publishers to meet the selection criteria, strictly established by these systems, which generally meet the international standards for the issuance of scientific periodicals. As one of the 13 criteria for selection of journals in Scopus is online accessibility - accessibility to the journal site with a mandatory English version and the quality of the journal site, the ACCESS team has created a platform for periodic electronic publications.

Each university needs objective data for assessment of the science, for making decision for further development.

Main problems of the quantity assessment of publications are an insufficient number of journals in Scopus and Web of Science. 


\section{Main features of ACCESS Journal Platform}

- Each journal has a dedicated website, which by request can have a custom design

- Journal websites have a dedicated subdomain myjournalname.access-bg.org, but by request the journal can use a dedicated domain myjournalname.com and still use the ACCESS platform

- Each journal website has informational sections - description of the journal subject, editorial board, review policy, open access policy

- Each journal website has a contact page to contact the journal team

- Each journal has an archive with all the issues and their articles

- Each journal website has a search functionality only in the context of the journal, results from the rest of the platform are not included

- By request each journal structure can be customized

- Journal websites are built in English, but by request they can be customized to be multi-language

- The main platform website has links to each journal website

- The main platform search and browse functionalities include all issues and articles from the journal websites, linking to them

- The main platform and each journal website is with responsive design and mobile-friendly

\section{Administration}

- Each journal administrator has access to a control panel to administrate their content and upload new issues

- The control panel is user-friendly and with responsive design, working equally well on all kinds of mobile and desktop devices

- Administrators can add, edit, remove issues

- Administrators can add, edit, remove articles

- Administrators can manage most of their site content 


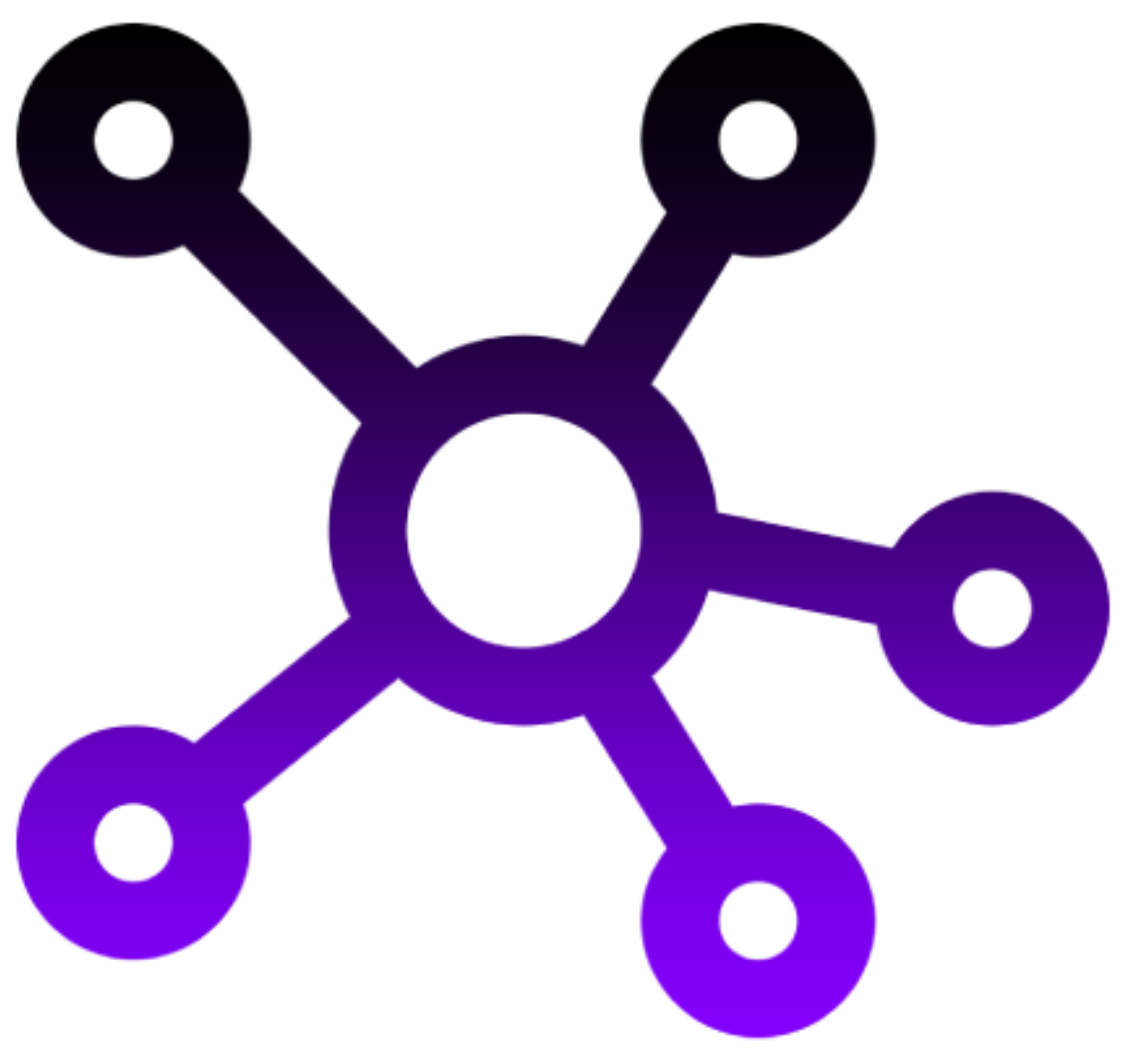

ACCESS JOURNAL

2021

Website: https://access-bg.org/

Email: office@access-bg.org; editors@access-bg.org

Phone: Bulgaria + 359 (0) 886-842-129 
ACCESS: Access to science, business, innovation in digital economy, ISSN 2683-1007 (online)

Volume 3, Issue 1, January 2022

CONTENTS

Mariana PETROVA, Sultan RAMAZANOV

EDITORIAL

\section{ARTICLES}

Nana SHONIA, Zurab MUSHKUDIANI, Maia SIRADZE

PANDEMIC ERA AND ITS IMPACT ON THE INVESTMENT AND BUSINESS ENVIRONMENT GEORGIAN CASE

Svitlana LABUNSKA, Oleksandr ZYMA, Serhii SUSHCHENKO

THE USE OF INFORMATION SYSTEMS AS A WAY OF SMALL AND BIG TOURISM ENTERPRISES INTERACTION ENSURING

Tatjana ODINOKOVA, Yerbol AKHMEDYAROV

INNOVATION ACTIVITY RESEARCH MODEL

Giga ABUSERIDZE, Mariana PETROVA, Vitolds ZAHARS, Vladas TUMALAVICIUS

TRANSFORMATION OF GEORGIA'S TRADE POLICY STRATEGY: FROM FRAILTY TO SUSTAINABILITY

EImira UTEUBAYEVA

INNOVATION RESEARCH MODEL FOR COMPETENT PROFESSIONAL COMMUNICATION IN A FOREIGN LANGUAGE FOR POSTGRADUATE SCHOOL LAWYERS.

Yoana KONSTANTINOVA

CULTURAL TOURISM DEVELOPMENT IN THE TOWN OF BYALA - OPPORTUNITIES FOR INNOVATION

REVIEWS, ANNOTATIONS, SCIENTIFIC and ACADEMIC SPEECH

Nguyen Van TRU

EFFICIENCY ASSESSMENT OF COMMERCIAL BANKS IN BULGARIA

by author Sergey RADUKANOV

(Monograph Review)

Guidelines for authors

Advertisements 